\title{
IUCN
}

Упатство за користење на

Глобалниот стандард на IUCN за решенија засновани врз природата

Рамка, приспособена на корисниците, за верификација, дизајнирање и сразмерно зголемување на решенијата засновани врз природата

\section{Прво издание}

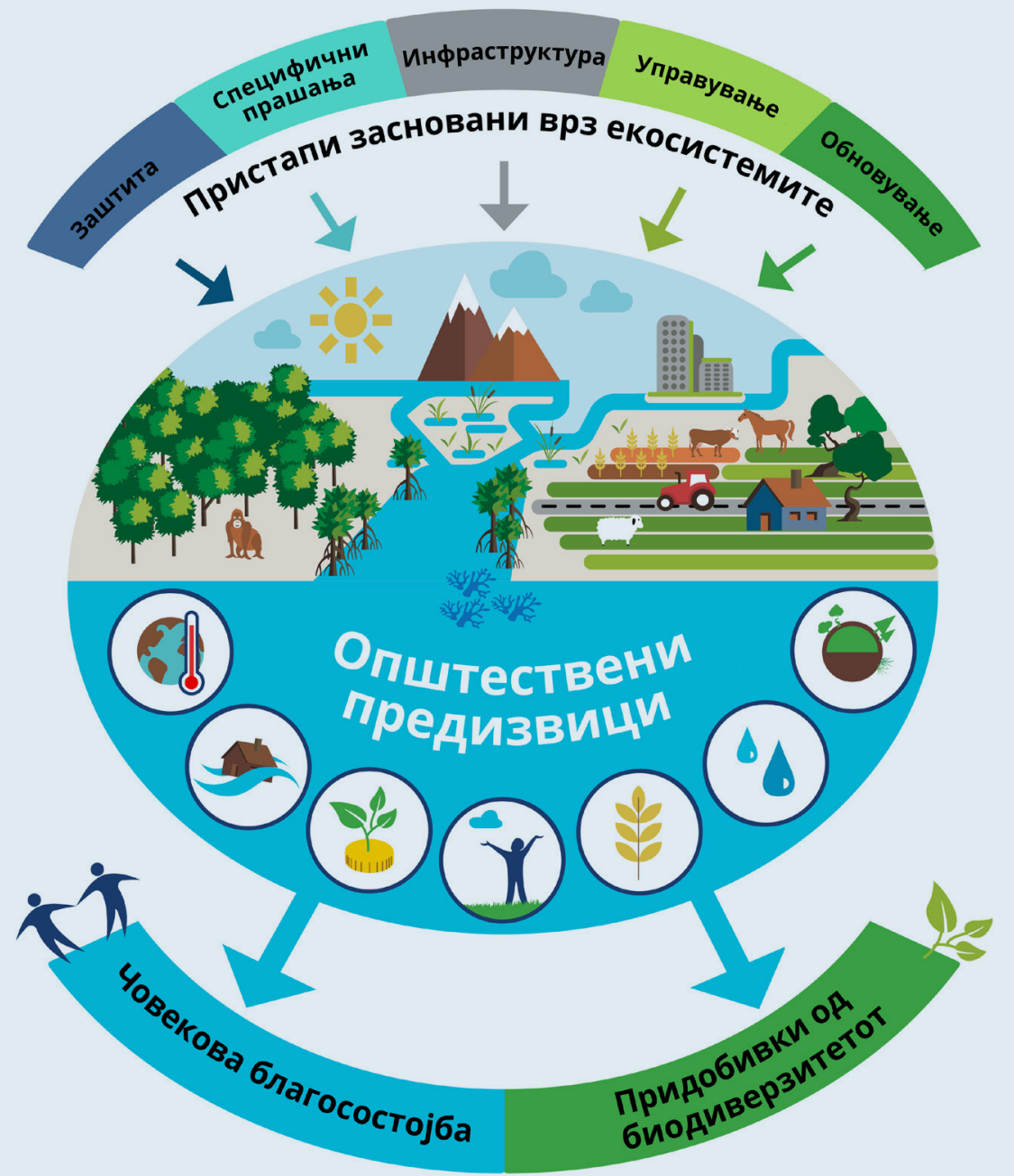




\section{3a IUCN}

IUCN е унија од членки уникатно составена и од владини и од граѓански организации. На јавните, на приватните и на невладините организации им нуди знаење и алатки со цел да се овозможи да се случат истовремено напредокот на луѓето, економскиот напредок и заштитата на природата.

IUCN е основана во 1948 година и денес е една од најголемите и најразновидните еколошки мрежи во која се спојуваат знаењето, ресурсите и опфатот на повеќе од 1400 членски организации и околу 15000 експерти. Унијата претставува водечки давател на податоци во областа на заштитата, проценката и анализата. Благодарение на широкото членство, IUCN има улога на инкубатор и доверлива база на најдобри практики, алатки и меѓународни стандарди.

IUCN обезбедува неутрален простор во чиишто рамки различните заинтересирани страни, вклучувајќи ги и владите, НВО, научниците, бизнисите, локалните заедници, здруженијата на домородните народи и останатите може да соработуваат со цел изнаоѓње и спроведување решенија во однос на предизвиците од животната средина и заради постигнување одржлив развој.

При соработката со многубројните партнери и поддржувачи, IUCN на светско ниво спроведува голем број разновидни проекти за заштита. Со комбинирање на најновите научни сознанија и традиционалното знаење на локалните заедници, целта на овие проекти е да се запре загубата на живеалиштата, да се обноват екосистемите, како и да се подобри човековата благосостојба.

www.iucn.org

https://twitter.com/IUCN/ 
Упатство за користење на

Глобалниот стандард на IUCN за решенија засновани врз природата

Рамка, приспособена на корисниците, за верификација, дизајнирање и сразмерно зголемување на решенијата засновани врз природата

Прво издание 
Означувањето на географските субјекти во оваа книга и презентацијата на материјалите не подразбираат изразување на какво било мислење од страна на IUCN или на останатите организации учеснички во однос на правниот статус на дадена земја, територија или област или нивните власти, ниту, пак, во однос на утврдувањето на нивните граници.

Ставовите изразени во оваа публикација не ги отсликуваат ставовите на IUCN или на останатите организации учеснички.

IUCN има задоволство да ја признае поддршката од своите рамковни партнери кои ги обезбедија основните финансиски средства: Министерството за надворешни работи на Финска; Владата на Франција и Француската агенција за развој (AFD); Министерството за животна средина, Република Кореја; Норвешката агенција за соработка и развој (Норад); Шведската агенција за меѓународна соработка и развој (СИДА); Швајцарската агенција за развој и соработка (СДЦ) и Стејт департментот на САД.

IUCN не презема одговорност за грешки или пропусти во овој превод или отстапувања од верзијата на оригиналниот јазик на публикацијата. Во случај на разлики, погледнете во оригиналната публикација. Наслов на оригинална публикација: IUCN (2020). Guidance for using the IUCN Global Standard for Nature-based Solutions. A user-friendly framework for the verification, design and scaling up of NbS. First edition. Објавено од: IUCN, Глан, Швајцарија. DOI https://doi.org/10.2305/IUCN.CH.2020.09.en

Ова Упатство го придружува Глобалниот стандард за решенија засновани врз природата на IUCN (https://doi.org/10.2305/ IUCN.CH.2020.08.mk) и обезбедува научна основа и упатства за корисниците.

Изработката на оваа публикација делумно е реализирана и од средства од Групата на француската агенција за развој (AFD) (Agence Française de Développement (AFD) Group), преку партнерството меѓу Франција и IUCN за природа и развој.

Објавено од:

Авторски права:
IUCN, Глан, Швајцарија

(c) 2020 IUCN, Меѓународна унија за заштита на природата

(c) 2021 Регионална канцеларија на IUCN за источна Европа и централна Азија за преводот на македонски јазик

Дозволена е репродукција на публикацијата за образовни и други некомерцијални цели без претходна писмена согласност од носителот на авторските права, под услов целосно да се наведе изворот.

Забранета е репродукција на публикацијата за препродажба или други комерцијални цели без претходна писмена согласност од носителот на авторските права.

Цитирање: IUCN (2021). Упатство за користење на Глобалниот стандард на IUCN за решенија засновани врз природата. Рамка, приспособена на корисничите, за верификација, дизајнирање и сразмерно зголемување на решенијата засновани врз природата. Прво издание. Глан, Швајцарија: IUCN.

ISBN: 978-2-8317-2154-5 (PDF)

978-2-8317-2155-2 (print)

DOI:

https://doi.org/10.2305/IUCN.CH.2020.09.mk

Преведено од: Ида Блажевска

Илустрација на корицата: Дефинирање на решенија засновани врз природата () IUCN

Дизајнирано од: Имре Себестјен (Imre Sebestyén jr)/ Unit Graphics

Испечатено од: Достапно од:

\section{GRAFIK CENTAR d.o.o.}

IUCN, Меѓународна унија за заштита на природата

Група за решенија засновани врз природата

Улица „Моверни“ 6р. 28 (Rue Mauverney 28)

1196 Глан, Швајцарија (1196 Gland, Switzerland)

NbSStandard@iucn.org

www.iucn.org/resources/publications

Текстот на оваа книга е испечатен на хартија направена од влакна од дрво добиено од добро управувани шуми сертифицирани во согласност со правилата на Советот за одговорно управување со шумите (FSC). 


\section{Содржина}

Историјат на документот ....................................................... vi

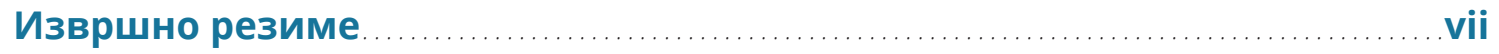

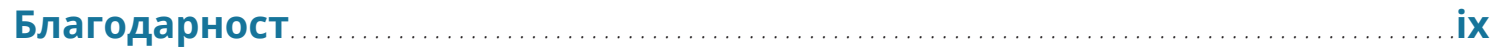

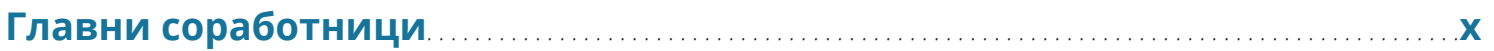

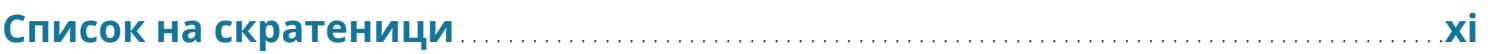

1. Вовед

1.1 Развој од почетен концепт до глобален пристап.................................... 1

1.2 РЗП како генеричка рамка за решавање на општествените предизвици ........ 4

1.3 РЗП во контекстот на кризата на биодиверзитетот ................................... 5

1.4 РЗП во контекстот на климатската криза .......................................... 5

1.5 РЗП во контекстот на кризата со инклузивноста.................................... 8

2. Воведување на Глобалниот стандард на IUCN за Р3П ................. 10

2.1 Потребата за глобален стандард .................................................. 10

2.2 Опсег на Стандардот ............................................................. 11

2.3 Примена и целна публика.......................................................... 11

3. Процес на заеднички развој на Глобалниот стандард .................13

3.1 Основи во дефинициската рамка на IUCN за РЗП .............................. 13

3.2 Преглед на процесот на заеднички развој ........................................ 14

3.3 Меѓународен кодекс за стандарди за одржливост ................................ 15

4. Упатства за Критериумите .................................................. 16

4.1 Резиме ......................................................................... 16

Критериум 1: Со РЗП ефективно се решаваат општествените предизвици ..... 17

К-1.1 Се врши приоритизирање на најнеодложните општествени предизвици за имателите на права и корисниците

K-1.2 Разгледаните општествени предизвици се јасно разбрани и документирани

K-1.3 Утврдени се исходите за човековата благосостојба што произлегуваат од РЗП и за истите се определени споредбени критериуми и периодично се оценуваат .............................................. 18

Критериум 2: Дизајнирањето на РЗП зависи од обемот .............................. 19

K-2.1 Со дизајнот за РЗП се препознаваат и се обезбедува одговор на интеракциите меѓу економијата, општеството и екосистемите......... 19

К-2.2 Дизајнот за Р3П е интегриран со другите комплементарни интервенции и бара синергии во рамките на секторите............................ 20

К-2.3 Во дизајнот за Р3П се вклучува утврдување на ризиците и управување со ризиците надвор од местата на интервенција...................... 21

Критериум 3: NР3П резултира во нето-добивка за биодиверзитетот и интегритет на екосистемот........................................................ 22 
К-3.1 Активностите на РЗП директно одговараат на оценката заснована врз докази на актуелната состојба на екосистемот и на превладувачките двигатели на деградацијата и загубата

К-3.2 Јасните и мерливи конзервациски резултати за биодиверзитетот се утврдени, определени се споредбените критериуми и истите периодично се оценуваат .

K-3.3 Следењето (мониторингот) вклучува периодични проценки на непосакуваните негативни последици врз природата кои произлегуваат од РЗП.

K-3.4 Можностите за јакнење на интегритетот на екосистемот и неговата поврзаност се утврдени и вградени во стратегијата за РЗП........... 24

Критериум 4: РЗП се економски одржливи ................................... 26

К-4.1 Директните и индиректните придобивки и трошоци поврзани со РЗП, кој плаќа и кој има придобивки, се утврдени и документирани. ....... 27

К-4.2 Се обезбедува студија за економичност за да се поддржи избирањето на РЗП, вклучително и веројатното влијание од кои било релевантни прописи и субвенции

K-4.3 Ефективноста на дизајнот за Р3П се оправдува во однос на достапните алтернативни решенија, притоа земајќи ги предвид кои било поврзани надворешни фактори

К-4.4 Во дизајнот за Р3П се зема предвид портфолио на можности за ресурси како што се обврските засновани на пазарот, јавниот сектор, доброволните обврски и активностите за поддршка на регулаторната усогласеност

Критериум 5: РЗП се засноваат врз инклузивни, транспарентни и зајакнувачки процеси на управување.

К-5.1 Дефинираниот и целосно утврдениот механизам за решавање жалби и добивање повратни информации е достапен за сите заинтересирани страни пред да започне интервенцијата со РЗП.

K-5.2 Учеството се заснова врз заемно почитување и рамноправност, без оглед на полот, возраста или општествениот статус и го почитува правото на домородните народи на слободна, претходна и информирана согласност (FPIC)

K-5.3 Заинтересираните страни што се под директно и индиректно влијание од РЗП се идентификувани и вклучени во сите процеси од интервенцијата на РЗП.

K-5.4 Со процесите за одлучување се документираат и се одговара на правата и интересите на сите заинтересирани страни што учествуваат и што се засегнати

K-5.5 Онаму каде што опсегот на Р3П излегува од правосудните граници, воспоставени се механизми за да се овозможи заедничко одлучување на заинтересираните страни во засегнатите надлежности............ 31

Критериум 6: РЗП рамноправно ги балансира компромисните решенија меѓу постигнувањето на нивните основни цели и континуираното обезбедување повеќекратни придобивки.

К-6.1 Потенцијалните трошоци и придобивки од поврзаните компромисни решенија за интервенцијата со РЗП се изречно потврдени и обезбедуваат информации за заштитните мерки и кои било соодветни корективни активности ........................................ 32 
K-6.2 Правата, користењето и пристапот до земјиштето и ресурсите, заедно со одговорностите на различните заинтересирани страни, се потврдени и се почитуваат ........................................... 33

K-6.3 Воспоставените заштитни мерки периодично се ревидираат за да се осигури дека заеднички договорените ограничувања за компромисните решенија се почитуваат и не ги дестабилизираат сите РЗП .................. 33

Критериум 7: Со РЗП се управува на приспособлив начин, врз основа на докази ... 34

К-7.1 Стратегијата за Р3П е утврдена и се користи како основа за редовно следење и евалуација на интервенцијата

K-7.2 Планот за следење и евалуација е изготвен и се спроведува во текот на животниот циклус на интервенцијата.............................. 35

К-7.3 Рамката за итеративно учење која овозможува приспособливо управување се применува во текот на целиот животен циклус на интервенцијата ...................................................... 35

Критериум 8: РЗП се одржливи и интегрирани во рамките на контекст на соодветна надлежност............................................................. 36

К-8.1 Дизајнот на Р3П, спроведувањето и научените лекции се споделуваат за да се поттикне трансформативна промена ........................ 36

К-8.2 Со Р3П се обезбедуваат информации и се јакне олеснувањето на политичките и регулаторните рамки за поддршка на нивната употреба и интегрирање

K-8.3 Онаму каде што е релевантно, РЗП придонесува кон националните и глобалните цели за човечката благосостојба, климатските промени, биодиверзитетот и човековите права, вклучувајќи ја и Декларацијата на Обединетите нации за правата на домородните народи (УНДРИП) .......37

5. Како се користи Стандардот 


\section{Историјат на документот}

\section{Упатство за користење на глобалниот стандард на IUCN за}

решенија засновани врз природата

\begin{tabular}{|c|c|}
\hline Издание & 1.0 \\
\hline Изворен јазик & Англиски јазик. Достапни се официјални преводи. \\
\hline Одговорна единица & $\begin{array}{l}\text { Глобална програма за управување со екосистеми; Комисија на IUCN за } \\
\text { управување со екосистеми }\end{array}$ \\
\hline Изработено од & $\begin{array}{l}\text { Група на IUCN за решенија засновани врз природата; Комисија на IUCN за } \\
\text { управување со екосистеми }\end{array}$ \\
\hline Предмет (таксономија) & $\begin{array}{l}\text { Решенија засновани врз природата; стандард; делотворност на } \\
\text { управувањето; осигурување }\end{array}$ \\
\hline Датум на одобрување & Февруари 2020 година \\
\hline Одобрено од & Советот на IUCN \\
\hline Цел & $\begin{array}{l}\text { Давање упатства и глобална рамка за дизајнирање, верификација и сразмерно } \\
\text { зголемување на решенијата засновани врз природата. Стандардот вклучува } \\
\text { глобално усогласени критериуми и показатели, кои се поддржани од Начелата } \\
\text { за решенија засновани врз природата, со цел мерење на интензитетот на } \\
\text { интервенциите. }\end{array}$ \\
\hline Дел е од & Групата за решенија засновани врз природата на IUCN \\
\hline Во согласност е со & $\begin{array}{l}\text { Системот на IUCN за управување со животната средина и социјалните } \\
\text { аспекти (ESMS) } \\
\text { Кодексот за поставување стандарди за добра практика на ISEAL. }\end{array}$ \\
\hline Поврзани документи & $\begin{array}{l}\text { Основен документ за глобални стандарди за Глобалниот стандард за } \\
\text { решенија засновани врз природата на IUCN }\end{array}$ \\
\hline Дистрибуција & IUCN COMPASS; Портал на Унијата на IUCN и веб-страница на IUCN \\
\hline
\end{tabular}

\section{Историјат на документот} Верзија
0.1 Објавено на

\section{Моментално прво издание}

\section{Резиме на измени и дополнувања}

\begin{tabular}{ccl}
0.1 & Октомври 2018 год. & $\begin{array}{l}\text { Споделен внатрешно со членовите, со комисиите и со секретаријатот } \\
\text { на IUCN. }\end{array}$ \\
\hline 0.2 & Декември 2018 год. & $\begin{array}{l}\text { Направени се измени во согласност со добиените повратни } \\
\text { информации, а новата верзија беше презентирана на првата јавна } \\
\text { консултација, која траеше еден месец. }\end{array}$ \\
\hline 0.3 & Јануари 2019 год. & $\begin{array}{l}\text { Поголеми измени и дополнувања беа направени во согласност со } \\
\text { надворешните повратни информации и новата верзија беше презентирана } \\
\text { На втората јавна консултација, којашто траеше два месеци. }\end{array}$ \\
\hline 0.4 & Февруари 2020 год. & $\begin{array}{l}\text { Измените беа направени во согласност со повратните информации од } \\
\text { втората јавна консултација усвоена од страна на Советот на IUCN кој го } \\
\text { одобри објавувањето на 98-та седница во светското седиште на IUCN } \\
\text { во Глан, Швајцарија. }\end{array}$ \\
\hline 0.5 & Март 2020 год. & $\begin{array}{l}\text { Направени се измени врз основа на ревизиите од надворешните } \\
\text { експерти. }\end{array}$ \\
\hline
\end{tabular}




\section{Извршно резиме}

Иако планетарните кризи со кои се соочуваме денес изгледаат навистина сериозно, општествата покажаа дека можат да соработуваат меѓусебно со цел за решавање на крупните глобални закани. Во 1970-те, светот презеде успешни акции за спречување на намалувањето на озонската обвивка и подобрување на нејзината состојба.

Доколку ваквите активности доживееја неуспех, тоа би значело дека „озонската дупка" сега би се протегала до тропските предели, што би влијаело врз здравјето на луѓето, екосистемските услуги и биодиверзитетот. За да се смени предвидената траекторија на дадената криза, потребни се веднаш достапни, сигурни и делотворни решенија. Во тој поглед, концептот на решенија засновани врз природата (РЗП) му нуди на светот вистинска можност за издржано решавање на повеќекратните кризи на одржливоста, вклучувајќи ги и климатските промени, достапноста на храната и водата, деградацијата на земјиштето и загубата на биодиверзитетот.

Веќе покажавме дека со заедничка работа и со примена на најдобрите практики имаме капацитет да изнајдеме трајни решенија коишто може да ни помогнат при транзицијата кон поправичен, поеднаков и поодржлив начин на населување на планетата. Глобалниот стандард на IUCN за решенија засновани врз природата е резултат од работата на повеќе од 800 експерти, во комбинација со знаењата и познавањата за тоа како природата може да се искористи како делотворен сојузник во борбата против климатските промени и останатите големи предизвици со кои се соочуваме во 21-от век.

Заштитата, одржливото управување и обновување на природата може да имаат значителни придобивки за општеството. Сепак, сето тоа е можно само доколку сите имаме заедничка визијаза тоа што претставувааттаквите решенија, конзистентен пристап за нивното осмислување и спроведување и, најважно, рамка за учење која ќе ни помогне да проценуваме, да се приспособуваме и да се подобруваме, за идните интервенции да бидат што поефикасни.

Целта на Стандардот е да ги олесни процесите, со цел не само да го води корисникот при дизајнирањето и спроведувањето на решенијата, туку исто така и континуирано да ја подобрува отпорноста на идните интервенции и да помогне во подготвувањето за неочекуваното. Стандардот се заснова врз премисата дека секое решение по својата природа треба да одговара на дадениот контекст и дека исходите ќе варираат зависно од околностите. Стандардот нуди конзистентен пристап којшто може да се справи со голем број поединечни околности и контексти и да се приспособи на нив, со цел добивање резултати што се еколошки издржани, социјално правични и економски изводливи, безпритоа да се изостави ниту една засегната страна.

Со помош на 8 критериуми и 28 показатели, на корисниците им се нуди поддршка при 1) проценката на обемот до којшто дадено решение се квалификува како РзП и при идентификувањето кои дејства може да се преземат со цел дополнително зајакнување на обемот на интервенцијата, со помош на скала со различни степени: "многу", „соодветно“, "делумно“ и „недоволно“; 2) дизајнирање целисходно решение кое ќе биде во согласност со критериумите и показателите, притоа вградувајќи механизми за приспособливо управување со 
цел да се одржи релевантноста и робусноста на решенијата во текот на нивниот животен век.

Стандардот е наменет за голем опсег на корисници, а особено за оние кои доагаат надвор од традиционалниот сектор за заштита. Заедно со него се дадени материјали што се пристапни и лесни за користење и самопроверка, додека ревизиите и измените на стандардот се прават под надзор на Меѓународната комисија за стандарди. Во согласност со тоа, IUCN го поддржува воспоставувањето глобална заедница на корисници кои колективно може да учат и да помагаат во еволуцијата на Стандардот.

- Со Критериумот 1 се разгледува важностана јасното идентификување на општествените предизвици за коишто ќе биде потребно решение. Понекогаш може да се опфатат повеќе од еден клучен приоритет. Намерата на овој критериум е да се овозможи целисходен дизајн со цел исполнување на потребите за човековата благосостојба.

- Критериумот 2 служи како водич за дизајнирање на РЗП во однос на клучните просторни фактори, што често се нарекува пристап на предел.

- Критериумите 3, 4 и 5 се однесуваат на трите клучни димензии на одржливиот развој - еколошката одржливост, социјалната еднаквост и економската изводливост.

- $\quad$ Со Критериумот 6 се опфаќаат практичните аспекти на примената и балансирање на компромисните решенија (trade-offs), коишто сенеразделен делоднајголем делод решенијата за управување со природните ресурси, вклучувајќи го и усогласувањето на краткорочните и долгорочните потреби. со него се истакнува дека одлуките за компромисни решенија треба да се носат целосно транспарентно, врз основа на целосно обелоденување на информациите и со постигнување консензус меѓу сите заинтересирани страни.

- $\quad$ Со Критериумот 7 се промовира пристап на приспособливо управување, каде што учењето и дејствувањето меѓусебно се надополнуваат со цел корисниците на стандардот да можат да го развијат и да го подобрат даденото решение.

- Co Критериумот 8 се промовира интегрирање во рамки на националните политики, што е од суштинска важност за долгорочната одржливост и трајноста на РЗП. Сето тоа може да се постигне преку усогласување со политиките, со националните и глобалните заложби, како и преку споделување лекции со цел изнаоѓање други решенија.

Стандардотеразвиенвовремекогасветотсебори против ширењето на КОВИД-19. Вниманието е моментално насочено кон заздравувањето на економијата по завршувањето на пандемијата. Поради тоа што светските лидери размислуваат како повторно да се изгради сѐ, решенијата засновани врз природата нудат единствена можност за инвестирање во општествената благосостојба и за раздвижување на економиите без повторување на грешките од минатото. 


\section{Благодарност}

Изработката на овој Стандард е плод на заедничките напори на голем број ангажирани поединци, групи и мрежи. Би сакале да им се заблагодариме на сите оние кои придонесоа кон изготвувањето на овој извештај. Техничкиот придонес е дело на голем број експерти од Секретаријатот на IUCN и од Комисијата за управување со екосистеми (KУЕ). Особено им се заблагодаруваме за придонесот на следните лица - Али Раза Разви, Мадхав Карки, Барбара Накангу, Фабрис Рено, Луцила Боито, Стивен Н. Едвардс, Бернал Херера, Вилем Ферверда, Џонатан Дејвис, Џон Вог, Мајк Џонс, Биргај Ламизана, Џени Спрингер, Келвин Пасфилд, Чарлс Лор, Венди Атиено, Ребека Велинг, Анита Цец, Едмунд Бероу, Мирјам Кузи, Ли Ен Хрт и Џонатан Хјуз. Им се заблагодаруваме и на сите оние кои дадоа коментари на претходните верзии на документот, вклучувајќ ги и стотиците учесници од 100 земји кои учествуваа во двете јавни консултации, со што се збогати квалитетот и опсегот на Стандардот. Особено им се заблагодаруваме на групата соработници од Францускиот национален комитет на IUCN, „Конзервејшн Интернешенел“, Светската комисија за заштитени подрачја на IUCN, Министерството за земјоделство на Франција, Центарот за закони во областа на екологијата на IUCN, Националната коалиција за капитал и Европската комисија.

Овој Стандард беше изготвен со помош на техничките познавања и советите за составување стандарди од „Ашуранс Сервисес Интернешенел“ (АСИ). Исто така, се заблагодаруваме и на Марни Бамерт од АСИ за стручната рецензија на публикацијата.

Исто така, се заблагодаруваме и на нашиот надворешен стручен рецензент Шантал ван Хам за мислењата со кои во голема мера се подобри квалитетот и опсегот на оваа публикација.

Им се заблагодаруваме на Каролин Сноу за уредувањето, на Имре Себестјен („Јунит Графикс“) за дизајнот и на Ефрат Бронштајн за графичкото уредување. Им се заблагодаруваме и на Глобалната единица за комуникации на IUCN и на Комуникациските групи за РЗП за нивната поддршка при комуникацијата и утврдувањето на графичките решенија.

Составувањето на извештајот беше овозможено благодарение на придонесот на Француската агенција за развој (AFD), преку Партнерството на Франција и IUCN за природа и развој.

За потенцијалните грешки се одговорни главните автори. 


\section{Главни соработници}

Стандардот е изготвен како консултативен напор, при којшто е искористена научната, уредувачката и техничката експертиза на голем број луѓе од IUCN и од Комисијата за управување со екосистеми. Авторите се наведени подолу по азбучен ред..

Andrade, Angela; Cohen-Shacham, Emmanuelle; Dalton, James; Edwards, Stephen; Hessenberger, Daisy; Maginnis, Stewart; Maynard, Simone; McElwee, Pam; Murti, Radhika; Nelson, Cara; Ruiz, Verónica; Siikamäki, Juha; Vasseur, Liette. 


\section{Список на скратеници}

\begin{tabular}{|c|c|}
\hline AFD & Француска агенција за развој \\
\hline ACИ & Ашуранс Сервисес Интернешенел \\
\hline КБР & Конвенција за биолошка разновидност \\
\hline KYE & Комисија за управување со екосистеми \\
\hline ЗСО3П & Заедница на стандарди за одржливост на заштитени подрачја \\
\hline KOO & Корпоративна општествена одговорност \\
\hline A3E & Адаптација заснована врз екосистеми \\
\hline HPK3E & Намалување на ризици од катастрофи засновано врз екосистеми \\
\hline СУЖССА & Систем за управување со животната средина и социјалните аспекти \\
\hline ОШП & Обновување на шумските предели \\
\hline ЧПП & Често поставувани прашања \\
\hline СПИС & Слободна претходна и информирана согласност \\
\hline MBO & Меѓувладина организација \\
\hline ИВЕУКМ & Интегрирано вреднување на екосистемските услуги и компромисните решенија \\
\hline МПНПБЕУ & Меѓувладина платформа за наука и политики за биодиверзитетот и екосистемски услуги \\
\hline МПКП & Меѓувладин панел за климатски промени \\
\hline ISBN & Регистрациски број на меѓународен стандард \\
\hline ISEAL & Меѓународен сојуз за општествена и еколошка акредитација и означување \\
\hline IUCN & Меѓународна унија за заштита на природата и природните ресурси \\
\hline LDN & Неутралност на деградација на почвата \\
\hline MnE & Мониторинг (следење) и евалуација \\
\hline РЗП & Решенија засновани врз природата \\
\hline НСАПБР & Национални стратегии и акциски планови за биолошка разновидност \\
\hline НУП & Национално утврдени придонеси \\
\hline РРПР & Рамка за раководење со природните ресурси \\
\hline ОЕЦД & Организација за економска соработка и развој \\
\hline ЦЛЗВ & Црвена листа на загрозени видовитм \\
\hline ЦОР & Цели за одржлив развој \\
\hline CPHPK & Рамка за намалување на ризиците од катастрофи од Сендаи \\
\hline $\mathrm{OH}$ & Обединети нации \\
\hline UNCCD & Конвенција на Обединетите нации за борба против опустинувањето \\
\hline UNDRIP & Декларација на Обединетите нации за правата на домородните народи \\
\hline UNFCCC & Рамковна конвенција на Обединетите нации за климатски промени \\
\hline УСД & Американски долари \\
\hline C3O & Светска здравствена организација \\
\hline
\end{tabular}





\title{
1. Вовед
}

\author{
„Решенијата засновани врз природата се дејства \\ преземени со цел за заштита, одржливо управување и \\ обновување на природните и изменетите екосистеми \\ на начини на коишто делотвортно и приспособливо \\ ќе се одговори на општествените предизвици, заради \\ обезбедување благосостојба на луѓето и придобивки \\ за биолошката разновидност."
}

Во 2020 година, сѐ повеќе се прифаќа фактот дека природата игра одредена улога во нашето општество. Меѓутоа, во текот на 20-от век, задолжените за донесување одлуки прашањето за заштитата на природата го третираа како периферно во однос на националните и на глобалните агенди. Во најдобар случај, се сметаше дека е прашање од одреден интерес, а во најлош, дека претставува пречка за развојот. Сепак, со растечкиот научен консензус се укажа дека таквите ставови се погрешно поставени и дека „природата е клучна за човековото постоење и добриот квалитет на живеењето". Ако не се препознае овој факт, не само што како резултат ќе се добие модел на економски раст со којшто се нарушуваат идните економии и којшто значително придонесува кон загуба на биодиверзитетот туку и ќе се испушти можноста за ефикасна употреба на природата во обезбедувањето помош за решавање на клучните општествени предизвици, како што се климатските промени, човековото здравје, достапноста на храната, намалувањето на ризиците од катастрофи итн. На тој начин се дава можност за насочување на конзервациските пристапи кон други сектори, како што се земјоделството, инфраструктурата, водата, здравјето, урбанистичкото планирање и руралниот развој.

Најголем дел од екосистемите може да дадат многукратни придобивки за различните корисници, истовремено поддржувајќи ја заштитата на базата на природни ресурси. Овој факт значи дека, честопати, управувањето со екосистемите е најдобрата алатка со која може да се решат општествените предизвици, а која притоа ја обезбедува и улогата на биодиверзитетот во секојдневното функционирање на останатите сектори.

\section{1 Развој од почетен концепт до глобален пристап}

Од 90-тите години на минатиот век наваму се развиени неколку пристапи за заштита што се засноваат врз наменско управување со екосистемите, како што се пристапот на обновување на шумските предели, одржливото управување со земјиштето, интегрираното управување со водните ресурси, интегрираното управување со пределите, интегрираното управување со крајбрежните зони, еколошкото обновување и Иницијативата на IUCN за 
одржливо искористување. Таквите оперативни пристапи даваат одредени конзервациски резултати што укажуваат дека постојат реални придобивки за општеството, како што се работни места, поголема продуктивност на земјиштето, контрола на ерозијата и врзување на јаглеродот. Зад секој од овие изрази стојат темелни истражувања и практична издржаност.

Без разлика дали се користат поединечно или во комбинација со други форми на решенија (како, на пр., технологија и инженерство), конзервациските пристапи (на пример, заштитата, обновувањето и одржливото управување) може исто така да се применат и со човековата благосостојба како примарна цел. Оваа еволуција во размислувањето за заштитата доведе до признавање на два широки домени на конзервациски интервенции, оние чијашто примарна цел е заштита на биодиверзитетот поради неговите вродени вредности и оние чијашто примарна цел е заштитата на општеството - она што сега се нарекува „решенија засновани врз природата“ (РЗП). и двата домени се држат до истите конзервациски норми и начела, и иако има случаи каде што оперативно се преклопуваат, почетната точка на овие домени е честопати прилично различна.

Исто така, оваа промена на парадигмата доведе до признавање дека различните земји имаат минато науправување со природата на начини од коишто произлегуваат придобивки за општеството, дури и ако во тоа време не се користел изразот РЗП за да се опишат ваквите интервенции. Иако сите овие конзервациски решенија биле корисни, одделно тие не се доволни за решавање на моменталните предизвици. Практичните и истражувачките заедници долго биле изолирани, често натпреварувајќи се за истите ресурси, и покрај сличните начела, цели и примени на конзервациските пристапи.

При привлекувањето поголемо внимание кон потенцијалот за конзервациски активности за одржливо искористување на природата за потребите на луѓето, концептот за РзП беше развиен како дел од една тековна парадигматска

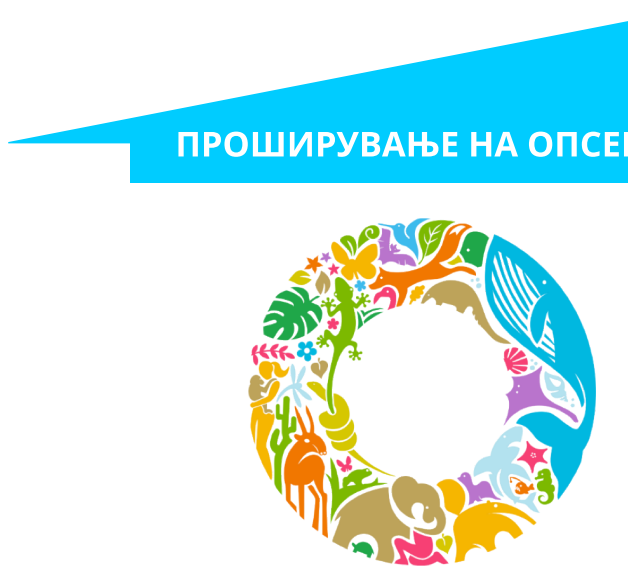

Заштита на природата

\section{Заштита на општеството}

\section{НОРМИ И НАУКА ЗА ЗАШТИТА НА ПРИРОДАТА}

слика 1: Конзервациските напори се држат до нормите и науката за заштита на природата. Постои домен во рамките на заштитата што се фокусира врз заштитата на биодиверзитетот поради неговата незаменлива вредност. Еден друг домен се фокусира врз заштитата на општеството, притоа следејќи ги таквите норми и начела за заштита на природата. Овој, вториот, е познат како решенија засновани врз природата. Иако постои одредено преклопување, не сите конзервациски интервенции се решенија засновани врз природата. (с) IUCN) 
промена која започна во 80-тите години, во рамките на која луѓето треба проактивно да ги штитат, да управуваат и да ги обновуваат екосистемите при решавањето на најголемите општествени предизвици, а не да делуваат како пасивни искористувачи на природата (CohenShacham et al., 2019). Во рамките на концептот за РзП се признава фактот дека заштитата на биодиверзитетот и екосистемските услуги се суштински за различните аспекти на човековата благосостојба, вклучувајќи го и човековото здравје. При справувањето со сложени системи, РЗП ги надминуваат традиционалните механистички пристапи кон решавање на проблемите (Rogers et al., 2013). Своите корени концептот на РЗП ги влече во екосистемскиот пристап (CBD, 2004; Holling, 1973; Holling, 1978; Holling, 1986; Waltner-Toews \& Kay, 2005), што служи како основа за Конвенцијата за биолошка разновидност (КБР) (Smith \& Maltby, 2003).

Сега, во 2020 година, конзервациската заедница и поврзаните сектори се во центарот на едно глобално движење кое признава, промовира и налага користење на РЗП. Во текот на последните десет години, откако изразот беше утврден од страна на IUCN, пристапот доби многу поголема тежина, по што РЗП беа вклучени во политики, повици за добивање предлози, економски планови, истражувачки прашања и национални стратегии за биодиверзитет и климатски промени. Со ваквата сѐ поголема важност и инвестирање, се појави потреба од дефинирање на изразот и овозможување отпорни и економски ефикасни интервенции.

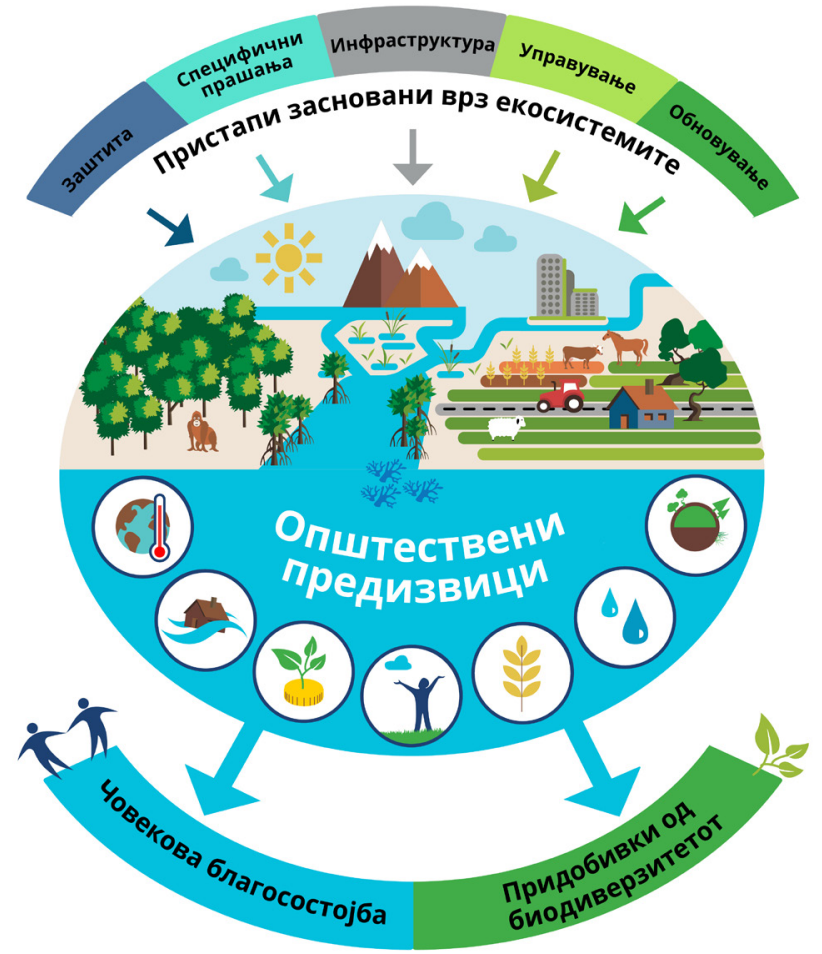

слика 2: Дефинирање решенија засновани врз природата () IUCN) 


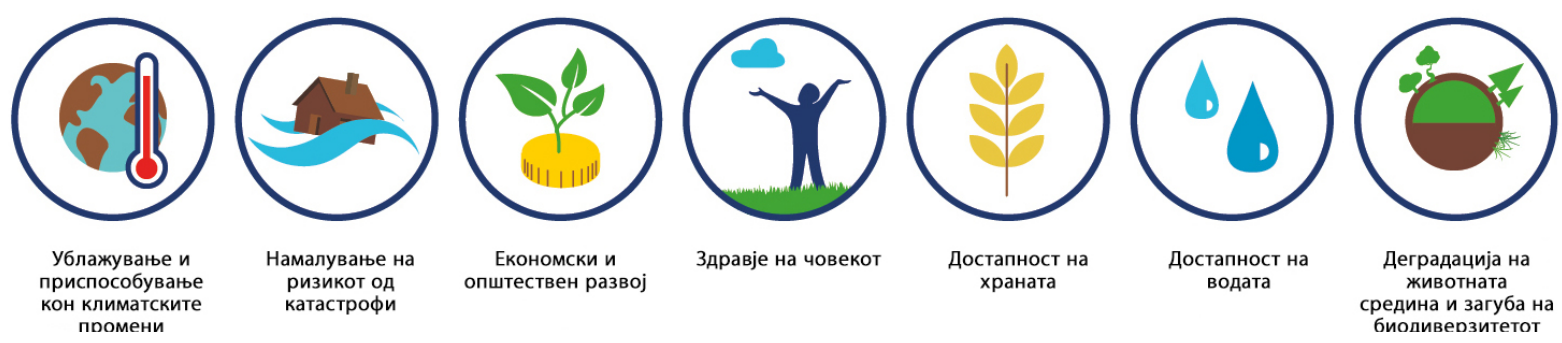

Слика 3: Најголеми општествени предизвици што се решаваат со P3П (๔ IUCN)

\section{2 Решенијата засновани врз природата како генеричка рамка за решавање на општествените предизвици}

Решенијата засновани врз природата се сметаат за генеричка рамка за пристапите засновани врз екосистеми (на пример, претходно спомнатите концепти) што се користат за решавање на крупните општествени предизвици (Cohen-Shacham et al., 2016, видете ја Слика 2). Изразот „решенија засновани врз природата“ првично беше промовиран од страна на IUCN во 2009 година, а потоа искористен како генерички израз со цел да се истакне заедничкиот карактер на различните конзервациски пристапи, вклучувајќи ги и претходно спомнатите. Останатите концепти коишто спаѓаат во категоријата РЗП вклучуваат: природни решенија (улогата на заштитените подрачја во борбата против климатските промени); адаптација заснована врз екосистеми (АЗЕ); намалување на ризиците од катастрофи засновано врз екосистеми (НРКЗЕ); зелена инфраструктура (за економски раст и инвестиции, во урбан контекст); природна инфраструктура (за одржливо интегрирано управување со водни ресурси); и холистичко или регенеративно управување со предели.

Ваквите пристапи и натаму ќе бидат од голема важност за спроведувањето на РзП. Тие служат како специфични оперативни пристапи коишто може да се применат при изнаоѓањето решенија за општествените предизвици. Можно е да се појави потреба од различни пристапи во рамките на дадена интервенција, а исто така можно е да се потребни дополнителни мерки со цел подобрување на ефикасноста и намалување на вишокот.

За дадена интервенција да се смета за РЗП, со неа на интегриран начин мора да се решава еден или повеќе општествени предизвици.. IUCN моментално упатува на седум општествени предизвици -ублажувањеиприспособувањекон климатските промени, намалување на ризиците од катастрофи, реверзија на деградацијата на екосистемите и загубата на биодиверзитетот, човековото здравје, социоекономскиот развој, достапноста на храна и достапноста на вода (видете ја Слика 3). Доколку се решава одреден општествен предизвик во однос на деградацијата на екосистемите, најмалку еден друг општествен предизвик мора да биде дел од дизајнот на решението, со цел да се направи јасна разлика меѓу интервенцијата за РЗП и чисто конзервациската активност.

Иако сѐ уште се во фаза на еволуција, решенијата на овие општествени предизвици моментално се применуваат. Тие се поддржани од научно знаење и добри практики коишто може да ја покажат вредноста на РЗП како одговор на проблемите. Поради тоа што концептот на РЗП веќе е подготвен за примена, во списокот може да се додадат и други општествени предизвици. 


\section{3 РЗП во контекстот на кризата на биодиверзитетот}

Меѓувладината платформа за наука и политики за биодиверзитет и екосистемски услуги (МПНПБЕУ) донесена во 2019 година, „Глобален извештај за оценување на биодиверзитетот и екосистемските услуги“ (ГИОБЕУ, 2019а), прикажува една мрачна слика за биодиверзитетот, каде што милиони видови растенија и животни се категоризирани под закана од истребување или се целосно истребени на глобално ниво, како и опаѓачки број на екосистемски услуги поради претераната експлоатација и злоупотреба. Брзата и драстична загуба на биодиверзитетот го еродира капацитетот на екосистемите за нудење услуги што се суштински за човековата благосостојба. Моменталната брзина со која исчезнуваат безрбетниците и почвените микроорганизми, преку интензивните практики на експлоатација на почвата, ги разнишуваат темелите на човековиот опстанок. Придонесот којшто природата го има за луѓето игра витална улога во поддржувањето на постоењето на човештвото и квалитетот на животот на луѓето, но често е нерамномерно распределен во просторот и времето (ГИОБЕУ, 2019 а). ГИОБЕУ укажува на тоа дека негативните ефекти се диспропорционални и особено влијаат врз маргинализираните и домородните народи и руралните заедници, чијшто опстанок директно зависи од придобивките од природата. Во ГИОБЕУ исто така се истакнува дека климатските промени се директен двигател којшто го влошува влијанието на останатите двигатели врз природата и човековата благосостојба (ГИОБЕУ, 2019 б) и ќе стане главен двигател за загуба на биодиверзитетот во наредните години, влијаејќи врз видовите, живеалиштата и екосистемите.

За дадено решение да се смета за Р3П, императивно е да овозможува истовремени придобивки и за биодиверзитетот и за човековата благосостојба. Според тоа, секое решение мора да придонесе за одржување или за подобрување на биолошката разновидност, без што дадена активност не може да се класификува како РзП. Ова е важно со цел да не дојде до нарушување на интегритетот и стабилноста на природниот систем со практики коишто за резултат имаат краткорочни придобивки, а притоа ја нарушуваат способноста на системот да ги опслужува идните генерации. Така, наместо зачувувањето на биодиверзитетот да биде резултат од дадено РЗП, од суштинска важност е фактот дека, доколку се одржува или се подобрува, ќе го валидира даденото решение како РЗП (IUCN, 2016 год.).

\section{4 РЗП во контекстот на климатската криза}

Од друга страна, во извештајот „Глобално затоплување од 1,5 C" на Меѓувладиниот панел за климатски промени (IPCC) се даваат доволно докази дека човекот со неговите активности предизвикал глобално затоплување од приближно 1,0 $\mathrm{C}$ над прединдустриските нивоа (ІРСС, 2018 год.). Според предвидувањата, во периодот меѓу 2030 и 2052 година, глобалното затоплување ќе достигне $1,5^{\circ} \mathrm{C}$, што ќе нѐ стави во многу опасна ситуација, доколку не се постигне целтаутврдена со Парискиот договор
- растот на глобалната просечна температура да се одржува „под 2 ㄷ над прединдустриските нивоа“ (видете го Полето 1 каде што се дадени примери од најважните наоди). Поради тоа што човештвото се соочува со катастрофална климатска критична точка, неминовна е потребата за изнаоѓње иновативни пристапи за надополнување на заштитата на природата, како и за непосредни трансформациски промени со цел намалување на емисиите на јаглероден диоксид за глобалното затоплување да 


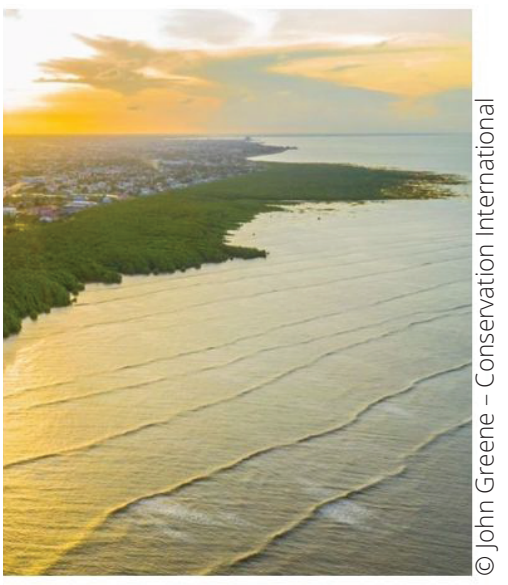

\section{Решенија засновани врз природата}
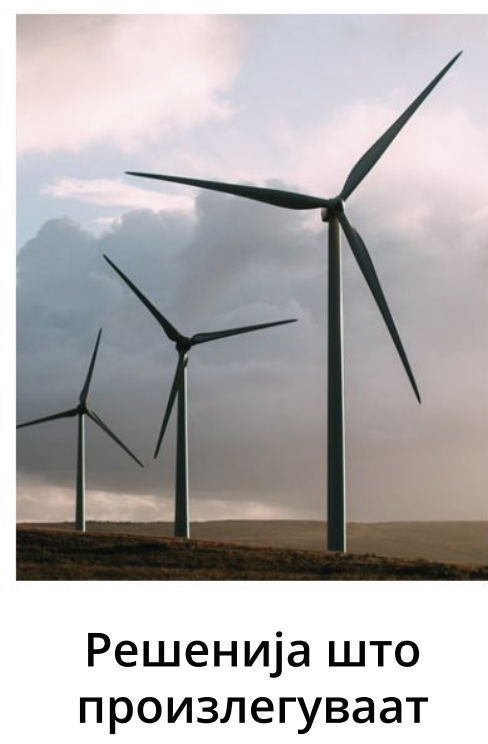

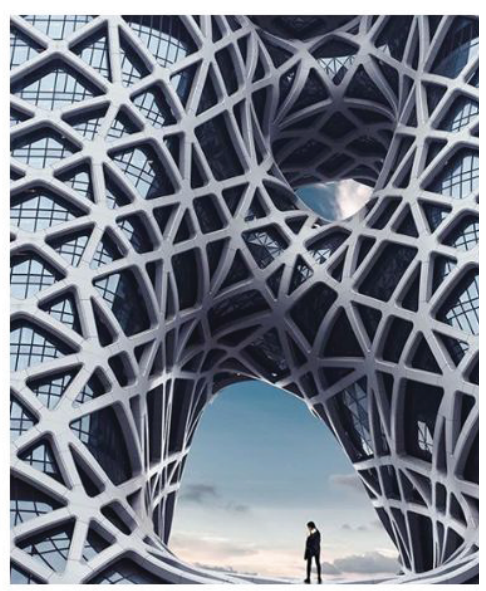

\section{Решенија што се инспирирани}

Слика 4: Додека решенијата засновани врз природата ја користат моќта на функционалните екосистеми како инфраструктура за обезбедување природни услуги од коишто корист имаат и општеството и животната средина, различни се решенијата што произлегуваат од природата и оние што се инспирирани од природата, коишто исто така се потребни за постигнување одржлива иднина со ниски нивоа на јаглероден диоксид. Решенијата што произлегуваат од природата вклучуваат енергија од ветер, бранови и сончева енергија, коишто помагаат во исполнувањето на потребите за нискојаглеродни извори на енергија преку производствени методи што произлегуваат од природни извори. Иако овие извори на енергија доагаат од светот на природата, тие директно не се засноваат врз функционални екосистеми. Решенијата засновани врз природата вклучуваат иновативен дизајн и производство на материјали, структури и системи коишто се моделирани врз основа на биолошки процеси и се инспирирани од природата. На пример, биомимикријата е практика која ги имитира и учи од стратегиите во природата со цел решавање проблеми. Овие дизајни се инспирирани од природата - како што се специјално направените лепливи ракавици што ја имитираат адаптацијата на геконите за качување по ьидови. Тие не се засноваат врз функционални екосистеми.

се ограничи на тој 1,5 ${ }^{\circ} \mathrm{C}$ (IPCC, 2018; Rockström et al., 2009; Steffen et al., 2015).

Концептот за РЗП овозможува интегриран пристап којшто на народите може да им помогне да ги исполнат круцијалните меѓународни договори и цели, како што се Целите за одржлив развој на Обединетите нации (ЦОР), Парискиот договор, Целите од Аичи, Бонскиот предизвик и Рамката за намалување на ризикот од катастрофи од Сендаи. Концептот за РЗП беше одобрен на Климатскиот самит на Обединетите нации во 2019 година и во Посебниот извештај на МПКП (IPCC) Глобално затоплување од 1,5 ${ }^{\circ} \mathrm{C}$ (De Coninck et al., 2018, во Извештајот на МПКП за климатските промени и земјиштето на МПКП(ІРСС, 2019год.) иво Глобалниот извештај за оценување на биодиверзитетот и екосистемските услуги (ГИОБЕУ, 2019 а) е истакнато дека има потенцијал за решавање на најголемите глобални и еколошки предизвици.
Со продлабочувањето на итноста во однос на климатските промени, и луѓето и природата ќе бидат сѐ повеќе ранливи поради изложеноста на времето и климатските екстреми, и иако влијанието ќе биде специфично за различните региони, генерално, луѓето и природата ќе се соочат со сѐ почести и поинтензивни негативни влијанија. Според Извештајот за климатските промени и земјиштето на МПКП, поголемата зачестеност на екстремни временски настани и промената на режимот на атмосферски врнежи веќе имаат влијание врз достапноста на храната на земјиштето (IPCC, 2019 год.), додека, пак, во Посебниот извештај на МПКПза океаните и криосферата во услови на променлива клима е укажано дека намалувањето на криосферата од средината на 20-от век исто така во голема мера има негативно влијание врз достапноста на храната и водата (ІРСC, 2019 год.). Врската помеѓу луѓето и природата е јасна во поглед на климатските промени. На пример, климатските промени ја 
влошуваат деградацијата на земјиштето, што исто така негативно влијае врз луѓето што живеат во деградираните подрачја (ІРСС, 2019 год.). Слично на тоа, климатските промени претставуваат висок ризик за крајбрежните екосистеми, како што се подводните ливади со морска трева и подводните шуми од морски алги келпи, каде што загубата на екосистемските функции (ІРСС, 2019 год.) од коишто зависат луѓето.

Меѓусебната поврзаност помеѓу луѓето и природата нуди можност, во форма на РЗП, за решавање на основните општествени предизвици (како што е достапноста на храна), притоа придонесувајќи за

\section{Поле 1: Примери од главните наоди од најголемите глобални извештаи (МПНПБЕУ (IPBЕS), 2019б; МПКП (IPC), 2018; ПвЦ и СветскИот фонд за природа (СФП) (РwC \& WWF), 2020):}

- Забележано е намалување на природните екосистеми во просек за 47 \% во споредба со првично евидентираните нивоа.

- $\quad$ Приближно 25 \% од видовите веќе се под закана од истребување во поголем дел од истражуваните животински и растителни групи, што укажува на тоа дека околу 1 милион видови веќе се соочуваат со истребување, од кои за голем дел може да се случи за неколку децении, освен доколку не се преземат дејства за намалување на интензитетот на двигателите на загубата на биодиверзитетот.

- Биотичката интеграција - бројност на природно присутни видови - се намалила во просек за 23 \% во земјените заедници.

- Глобалната биомаса на диви цицачи се намалила за 82 \%. Показателите на бројноста на 'рбетниците се намалиле рапидно од 1970-те години наваму.

• 72 \% од показателите развиени од страна на домородните народи и локалните заедници покажуваат тековно влошување на природните елементи важни за нив.

- Најголем дел од општествените и еколошките цели не може да се исполнат со тековните траектории и целите поставени за 2030 година и потоа може да се постигнат исклучиво преку трансформативни промени во рамките на економските, социјалните, политичките и технолошките фактори.

- Најделотворните директни двигатели на промените се промените на начинот на користење на почвата и морињата, директната експлоатација на организмите, климатските промени, загадувањето и инвазијата на надворешни видови.

- Се проценува дека човековите активности предизвикале глобално затоплување од приближно $1.0{ }^{\circ} \mathrm{C}$ над прединдустриските нивоа, со веројатен опсег на зголемување помеѓу 0,8 и $1,2^{\circ} \mathrm{C}$.

- Според предвидувањата, глобалното затоплување ќе достигне зголемување од 1,5 ${ }^{\circ} \mathrm{C}$ во периодот помеѓу 2030 и 2052 година, доколку продолжи со раст со моменталната стапка.

- Климатските промени предизвикуваат дополнителен стрес врз земјиштето, со што се влошуваат постојните ризици во однос на егзистенцијата, биодиверзитетот, здравјето на луѓето и на екосистемите, инфраструктурата и прехранбените системи.

- Трошоците за неактивноста во однос на загубата на биодиверзитетот се проценуваат на 4 - 20 трилиони американски долари годишно во екосистемските услуги во периодот од 1997 до 2011 година, што се должи на промените на покриеноста на земјиштето и околу 6 - 11 трилиони американски долари годишно поради деградација на земјиштето.

живеалиштата ќе доведе до губење на видовите и нивната разновидност и до деградација на адаптација на климата и ублажување на нејзиното влијание. Во Извештајот на МПКП (ІРCC) од 2019 
година, Извештај за климатските промени и земјиштето, се истакнува одржливото управување со земјиштето, вклучувајќи го и зачувувањето на екосистемите бидејќи тоа „може да придонесе за намалување на негативното влијание на повеќекратнитепредизвикувачи на стрес, вклучувајќи ги и климатските промени, врз екосистемите и општествата" (IPCC, 2019 год.). Примерите за адаптација заснована врз екосистеми што може да ги отстрани емисиите на стакленички гасови и да придонесе за ублажување и адаптација вклучуваат обнова на природните екосистеми и подобрување на зачувувањето на биодиверзитетот (IPCC, 2019 год.). Со цел ограничување на затоплувањето на 1,5 ${ }^{\circ} \mathrm{C}$ или далеку под $2{ }^{\circ} \mathrm{C}$, на општеството му е потребна комбинација одрешенија инспирирани одприродата, решенија што произлегуваат од природата и решенија што се засноваат врз природата, заедно со значајно намалување на емисиите на гасовите од фосилни горива (Слика 4).

Здравјето на екосистемите од коишто зависиме ние и сите други видови се влошува многу побрзо од кога и да било досега, со што подзакана се става здравјето на планетата и луѓето. Вршиме ерозија на самите темели на нашата економија, егзистенција, достапноста на храната, здравјето и квалитетот на животот насекаде низ светот. Во извештајот исто така се признава дека по 2020 година, климатските промени ќе станат еден од главните двигатели на загубата на биодиверзитетот. Сето ова налага потреба од истовремено анализирање и решавање на кризата со климатските промени прекуРЗП, што исто така игра важна улога во постигнувањето трансформациска промена потребна за постигнување на глобалните цели за одржливост.

РЗП може да бидат дел од хиерархискиот пристап за ублажување, што претставува рамка за носење одлуки во серија од чекори, почнувајки од избегнување влијанија, проследено со минимизирање на неизбежните влијанија, обновување на самото место и конечно, онаму каде што е тоа можно и потребно, преземање компромисни мерки за биодиверзитетот. Соодветната примена на хиерархијата на ублажувањето може потенцијално да ги ограничи негативните влијанија на развојните проблеми врз биодиверзитетот и може да донесе и дополнителни придобивки за заштитата на биолошката разновидност. Меѓутоа, несоодветната примена, особено ако се применува заедно со нерешени, но фундаментални празнини во знаењето, како и лошата корпоративна, финансиска и регулаторна политика, може да ги ослаби воспоставените пристапи кон управување со ризиците во однос на биодиверзитетот.

\section{5 РЗП во контекст на кризата со инклузивноста}

Интервенциите може да бидат успешни само доколку се вклучат различни системи на знаење и со учество на засегнатите групи, вклучувајки ги домородните народи, локалните заедници, жените и младите. За жал, ова не било секогаш случај во историјата на конзервациските активности, што довело до криза на инклузивноста, заедно со кризата со биодиверзитетот и климата. РЗП, поради нивниот интерсекторски пристап и интегрираниот начин на примена, имаатголемакористодспојувањето насите различни актери кои се директно или индиректно засегнати од интервенцијата и вклучуваат различни видови системи на знаење и светоглед, како оние втемелени во традиционалното еколошко или автохтоно знаење. На пример, постојните адаптациски напори во поларните региони секако дека имаат корист од вклучувањето на знаењето на домородните и локалните народи, поради тоа што околните трендови и структури на копнените/ приморските предели се менуваат, како и здравјето и популацијата на видовите (IPCC, 2019 год.).

При разгледувањето на разните засегнати страни во дадено РЗП, од суштинска важност е да се обезбеди активно, инклузивно и транспарентно учество, без оглед на полот, возраста или социјалното, 
економското или културолошкото потекло и со цел носењето одлуки во рамки на дадени РЗП да е транспарентно иправично, зарадизаштитаналуѓето и културата. Ова е исто така од суштинска важност за постигнување на целосните потенцијални придобивки од РЗП. Аспектите што може да влијаат и да ги маргинализираат потенцијалните придонесувачки субјекти во колаборативниот процес кои се користат во РЗП се културолошката пристрасност и елитистичките перспективи. Онаму каде што групите на засегнати страни имаат еднаква важност (на пример, рурални и нерурални), ваквите перцепции може да предизвикаат одредени групи да не ги земат предвид мислењата на пониските социјални класи и на помалку образованите членови на општеството. Таквите ситуации може да се ограничат и да се подобрат преку олеснување на конструктивни дискусии и соработки, процеси што се клучни за спроведување на дадено РЗП.

Домородните народи и локалните заедници особено располагаат и управуваат со значителен дел од еколошки најразновидните региони на Земјата и имаат витална улога во зачувувањето на земјиштето, морињата и ресурсите и нивното одржливо користење. Тие негуваат силни економски, културни и духовни врски со својата животна средина, развиле и често применуваат традиционални практики за управување и имаат знаење што придонесува кон подобрување на заштитата на биолошката разновидност и кон одржливото искористување на природните ресурси. На пример, домородните заштитени подрачја, каде што се почитува традиционалното и одржливото искористување на природните ресурси, може да претставуваат РЗП што ќе придонесат за опстанокот на традиционалното знаење и домородните заедници. Слично на тоа, управителите со рурално земјиште, без разлика дали се дел од домородните заедници, располагаат со поинформирано разбирање на земјиштето со кое управуваат за разлика од кој било друг.

Без разлика на тоа која засегната група се вклучува, секогаш ќе постои родовата компонента, при што примената на родовиот пристап е предуслов за одржливиот развој. Вклучувањето на жените во поддршката на РЗП оди во прилог на нивното спроведување, поради тоа што зачувувањето на природата и правата на жените се нераздвојни. На пример, деградацијата на животната средина го интензивира насилството против жените, па затоа примената на родово одговорен пристап кон РЗП може да придонесе и за биолошката разновидност и за надминување на кризата со инклузивноста. Во меѓувреме, голем број студии покажале дека со вклучувањето на жените всушност се искористува и нивното уникатно познавање на управувањето со природните ресурси. Поурамнотеженото родово водство и еднаквото вклучување на жените во РЗП резултира со поголеми придобивки за природата, а со тоа и за луѓето.

Заедно со зголемувањето на влијанието и видливоста на РЗП во последните неколку години, младите почнуваат да го кажуваат својот став и нивната улога во конзервациските активности стана повидлива. Децата и младите даваат материјален придонес во решавањето на суштинските општествени предизвици, нагласувајќи ја меѓугенерациската еднаквост, која претставува еден од условите. Интервенциите коишто имаат поголемо влијание врз краткорочните трошоци и придобивки, а коишто не ги земаат предвид долгорочните трошоци, придобивки и компромисни мерки, се помалку отпорни; вклучувањето на младите во дадена интервенција побудува почитување и разбирање на меѓугенерациското и, според тоа, и на долгорочното влијание, со што се гради отпорност. При разгледувањето решенија за климатските промени, особено се јавува недоволно внимание кон заштитата, вклучувањето и јакнењето на положбата на младите, при што само 8 од вкупно 160 Национално утврдени придонеси (НУП) вклучуваат директно споменување на меѓугенерациската неправда или идните генерации. Вклучувањето на младите во глобалното движење што ги поддржува РЗП ја поддржува одржливоста на ваквите интервенции, а истовремено се уважуваат и потенцијалните придобивки што едукацијата на младите ја има во однос на адаптацијата и ублажувањето на климатските промени. 


\section{2. Воведување на Глобалниот стандард на IUCN за РЗП}

\section{1 Потребата за глобален стандард}

Co cè поголемата популаризација на концептот на РЗП, се јави соодветна потреба за јасно разбирање, комуницирање и спроведување на стандардот на начин на којшто се операционализираат осумте основни начела на Р3П (IUCN, 2016 год.). Стандардите за практиката се вообичаен метод за постигнување на ваквите цели со развивањето на полињата на практика. Покрај тоа, важно е да се појасни дека иако РЗП делуваат како дополнување кон заштитата на природата, нивната главна цел е да се делува во поглед на еден или повеќе општествени предизвици, од што придобивка имаат и биолошката разновидност и човековата благосостојба. Оваа диференцијација е многу важна со цел да се осигури дека 1) заштитата и понатаму испорачува наменски активности за стопирање или намалување на загубата на биодиверзитетот, онаму каде што е потребно, и 2) заштитните активности се сенаменски и информативно дизајнирани како одговор на еден или повеќе општествени предизвици, притоа налагајќи иновативни партнерства и интеграција на повеќе пристапи (како што се комплементарностите со т.н. сива инфраструктура, односно хибридните решенија).

Следствено на тоа, со брзиот и сѐ поголем глобален интерес за РзП, се јавува потреба и за создавање релевантен и сеопфатен стандард според којшто ќе се врши дизајнирањето и спроведувањето на секое РзП, како и за утврдување дека таквиот стандард ќе го обезбеди следното:

- унифицирано разбирање и толкување на концептот за РЗП во рамките на различните сектори, корисници и географски локации;

координиран начин со другите засегнати сектори, корисници и географски локации;

- квалитетна контрола врз дизајнирањето и спроведувањето на интервенциите низ стандардизирани процеси што ќе овозможат отчетност;

- постојните релевантни алатки, пристапи и методи и нивното искористување се целосно земени предвидпри дизајнирањето и примената на дадено решение;

- минимизирање на ризиците поврзани со идното неодржливо искористување на природата и неможност за категоризирање како РЗП на дејства коишто може да се особено негативни за биодиверзитетот и општеството; и

- вклучување на повеќе сектори во спроведувањето и решавањето на општествените предизвици.

На тој начин, РЗП ќе придонесат кон трансформациска промена, со тоа што ќе станат составен дел од планирањето и спроведувањето на општствените одговори на таквите предизвици. 


\section{2 Опсег на Стандардот}

Глобалниот стандард на IUCN за РЗП претставува еден сеопфатен дефинитивен концепт што може да се спроведе преку постојните екосистемски пристапи и алатки, особено преку оние што се оперативни и партиципативни. Според тоа, толкувањето и спроведувањето на концептот за РЗП во голема мера зависи од контекстот, како и од големиот број различни фактори што влијаат врз општествените предизвици што се разгледуваат, вклучувајќи го и видот на екосистемот во дадениот копнен/приморски предел во којшто се применува даденото РЗП, социоекономскиот и културолошки систем и составот и односите во рамки на групите на заинтересирани страни. Поради тоа, може да се изврши стандардизација на процесите за дизајнирање и спроведување на РЗП, наместо да се очекува еден однапред пропишан исход од стандардот при секоја примена на дадено решение. Според тоа, Глобалниот стандард за РЗП е олеснувачки стандард што е наменет за обезбедување поширока застапеност и подобрување на дизајнот и на спроведувањето, но тој не ги регулира процесите што се применуваат за постигнување дадени конкретни резултати и исходи. Исто така, предвидено е процесот на спроведување на Стандардот за РЗП да обезбеди докази за тоа како се справуваме со еволутивните еколошки и општествени промени со текот на времето и придонес кон подобрувањето на развојот на потребните политики.

Стандардот на практичарите ќе им овозможи да го стандардизираат дизајнирањето и спроведувањето на Р3П преку: 1) поставување заедничка основа за разбирање што претставуваат Р3П, а што не; 2) давање придонес за трансформациските промени преку подобрување на практиката на РЗП и поддржување на разјаснувањето и развојот на политиките поврзани со РЗП.

\section{3 Примена и целна публика}

Стандардот е наменет да се користи од сите кои работат во областа на верификацијата, дизајнирањето и сразмерното зголемување на РЗП. Корисниците може да ги вклучуваат и раководителите на проекти во јавниот и во приватниот сектор, планерите на предели, развојните практичари и конзервационистите, владините тела или претставниците од финансискиот сектор (донатори и инвеститори), органите надлежни за креирање на политиките и планерите. Во оваа фаза, Стандардот има две функции - дава упатства за дизајнирањето на РЗП и овозможува начини за проверка дали дадениот дизајн ги исполнува барањата на Стандардот за РЗП.
- Дизајнирање - Критериумот ориентиран кон осум процеси одговара на најважните аспекти на дизајнирањето (и идното спроведување) за дадена интервенција да може да се квалификува како РзП. Како таков, критериумот соодветствува на циклус на проектното управување, притоа истакнувајќи ги најважните аспекти на размислувањето надвор од географскиот простор и временските ограничувања на даден проект и потребата за примена на приспособливо управување, поради тоа што дизајнот на РЗП се заснова врз теорија на промена што неизбежно ќе содржи претпоставки коишто ќе треба да се тестираат во текот на примената. 
- Верификација - при дизајнирањето на дадено решение, Стандардот може да се искористи за потврдување дали тоа се квалификува како РЗП. Оваа функција на Стандардот е важна за корисниците, како што се основачите и инвеститорите кои објавуваат повик за поднесување решенија. Исто така, минатите и тековните РЗП што датираат од пред развојот на овој стандард може да се проценат во однос на критериумите на стандардот, доколку намерата е дадената интервенција да може да се признае како РЗП.

- Сразмерно зголемување - одредени примери за РЗП се во согласност со добар дел од осумте критериуми на Стандардот, при што недостигаат само неколку. Голем дел од нив се пилот-проекти или интервенции кои моментално имаат ограничено време или претставуваат независен пристап.
Стандардот може да се користи за идентификување на силните кандидати за сразмерно зголемување и идентификување на јазовите со цел трансформирање на дадена интервенција во силно РЗП.

Покрај тоа, Стандардот е моментално дизајниран за да се користи како самооценување или верификациски процес на првата страна. Усогласен со пристапот на Стандардот за олеснување на поширокото навлегување на концептотнаРЗП, моменталносамооценувањето дава робустен, а истовремено флексибилен пристап кон дизајнирањето и спроведувањето на таквите решенија. Стандардот дава простор за повторливо учење и размислување, а не претставува ригиден нормативен процес на сертифицирање, поради тоа што светот сѐ уште ги разбира и ги толкува РЗП за различни потреби и во различни контексти. 


\section{3. Процес на заеднички развој на Глобалниот стандард}

\section{1 Основи во дефинициската рамка на IUCN за Р3П}

Главната цел на Р3П е да се поддржи постигнувањето на развојните цели на општеството и да се заштити човековата благосостојба на начини на коишто ќе се отсликаат културните и општествените вредности и ќе се подобри отпорноста на екосистемите, нивниот капацитет за обнова и обезбедување услуги (IUCN, 2016 год.). Заедно со рамката за дефиниција на РЗП на IUCN од 2016 година, во која РЗП беа дефинирани како „дејства за заштита, одржливо управување и обнова на природните или изменетите екосистеми, со кои делотворно и приспособливо се решаваат општествените предизвици, истовремено обезбедувајќ придобивки за човековата благосостојба и биодиверзитетот" (IUCN, 2016 година), членовите на IUCN усвоија и осум начела (IUCN, 2016 год.), што е прикажано на Слика 5. Оттогаш се изгради опсежна база на објавената литература, што уште повеќе ја потврдува оваа улога на РЗП во однос на заштитата.

Во една неодамнешна студија за начелата на РЗП (видете погоре) беше утврдено дека рамката на РЗП се протега и надвор од останатите слични методи (на пример, методот на обнова на

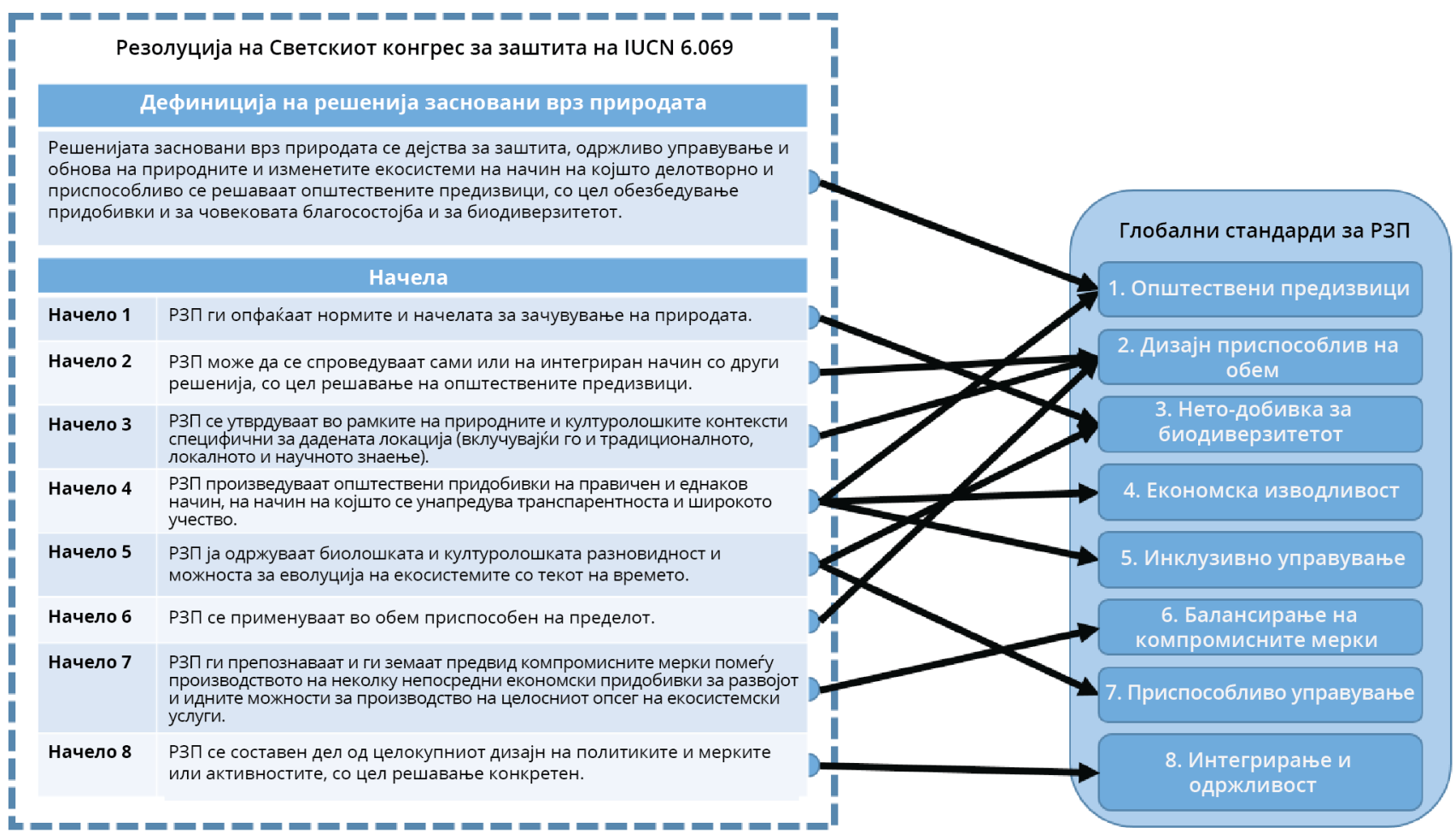

слика 5: Врска помеѓу начелата за РЗП и критериумите од Стандардот за РЗП (ㄷ IUCN) 
шумски предели (ОШП), адаптацијата заснована врз екосистеми (АЗЕ), пристапот на еколошка обнова, екосистемскиот пристап) преку три негови принципи (2, 6 и 8, односно на синергиите на РЗП со другите видови на решенија, примена при сразмер за копнен/приморски предел и за интеграција на политиките). Според тоа, РЗП може да се сметаат за главна рамка на серија добро воспоставени пристапи засновани врз екосистеми и поврзани со екосистеми (CohenShacham et al., 2019).

\section{2 Преглед на процесот на заеднички развој}

IUCN го олесни кодизајнирањето на стандардите за РЗП преку акумулирање на знаењето, вештините и искуствата на стручните лица од голем број заинтересирани страни. Таквото здружено развивање на Стандардот е важно, со оглед на тоа што РЗП претставуваат меѓусекторска тема и според тоа, има потреба од интеграција на неколку дисциплинарни полиња (на пример, екологија, општествени науки, политички науки, математика и економија) и различни форми на знаење (на пример, експериментално знаење, научно знаење и традиционално знаење), со цел определување информирани добри практики. Имаше два круга јавни консултации со повеќе од 800 заинтересирани (од јавниот и од приватниот сектор, како и невладини организации) од 100 земји.

До членовите на IUCN, неговите партнери, вклучувајќи и мултинационални компании, коалициски мрежи и донатори, беа доставени консултативни анкети. Исто така, Комисијата за управување со екосистеми (КУЕ) придонесе со својата научна ревизија на главните концепти, критериумите и показателите на четири состаноци на управниот комитет и организираше две работилници во Вашингтон, на коишто учествуваа неколку членови на лидерскиот тим. Сите мислења беа примени на писмено и во рамките на дискусии во живо со фокусните групи. Сите мислења потекнуваа од широките консултации, коишто во голема мера влијаеја и го оформија опсегот и содржината на Стандардот. Оваа конечна фаза на Стандардот беше усвоена на 98. состанок на Советот на IUCN. Стандардот беше објавен од страна на IUCN во 2020 година.

Во поглед на техничкиот метод на развивање на Стандардот, првиот преземен чекор беше да се мапираат осумте начела на РЗП, усвоени преку Резолуцијата на Светскиот конгрес за зачувување на природата на IUCN Resolution WCC-2016-Res-069-EN (IUCN, 2016) од страна на членките на IUCN, до тринаесетте постојни релевантни Стандарди, пристапи и насоки за рамки за управување со екосистемите. Заедничките начела и јазови меѓу рамките беа мапирани со цел да се воспостават заеднички основи на РЗП и елементите единствени за РЗП, со цел да се овозможи развој на стандард на IUCN. Користејќи го овој метод, првично беа развиени седум критериуми за внатрешна консултација, искористувајќи ги стручноста и искуството на IUCN. Врз основа на понатамошните разгледувања и консултации, беа одобрени осум критериуми за РЗП. 


\section{3 Меѓународен кодекс за стандарди за одржливост}

Од почетокот на развојниот процес на Стандардот, IUCN се заложи да го усогласи развојот на Глобалниот стандард на IUCN за Р3П, онолку колку што е можно, со Кодексот за добра практика на Меѓународниот сојуз за општествена и еколошка акредитација и означување (ISEAL): поставување општествени и еколошки стандарди. Оваа верзија на Глобалниот стандард на IUCN за РЗП е резултат од научените лекции во текот на јавните консултации спроведени во 2018 и во 2019 година.
Во Глобалниот стандард на IUCN за Р3П се наведени критериумите и показателите усвоени на 98. состанок на Советот на IUCN во 2020 година. Овој документ, Упатството за користење на Глобалниот стандард на IUCN за Р3П, е даден во прилог на оваа брошура со цел да се даде научна основа и упатства за корисниците. Еден друг документ, Делот III, подоцна ќе служи како упатство за корисниците, надградувајќи се од лекциите од пилот-проектите и ќе биде поврзан со алатката за самооценување, заедно со предлози за средства за проверка и дизајн, како и алатки за спроведување. 


\section{4. Упатства за критериумите}

\section{1 Резиме}

Стандардот се состои од осум критериуми, при што секој од нив има збир на показатели. Критериумите се цврсто засновани врз начелата на РЗП, како и врз повратните мислења добиени при консултациите.

Во Критериумот 1 сеисцртувапроцесот заутврдување на општествените предизвици со коишто се соочуваат заинтересираните страни и носителите на правата, како и за разбирање на поврзаните можности и предизвици. Дизајнот на решенијата мора да има за цел решавање на предизвиците, земајки ги предвид пошироките општествени, економски и еколошки контексти во чии рамки постојат и проблемот и решението, во согласност со Критериумот 2. Со вториот критериум се разгледува фактот дека иако спроведувањето на решението е

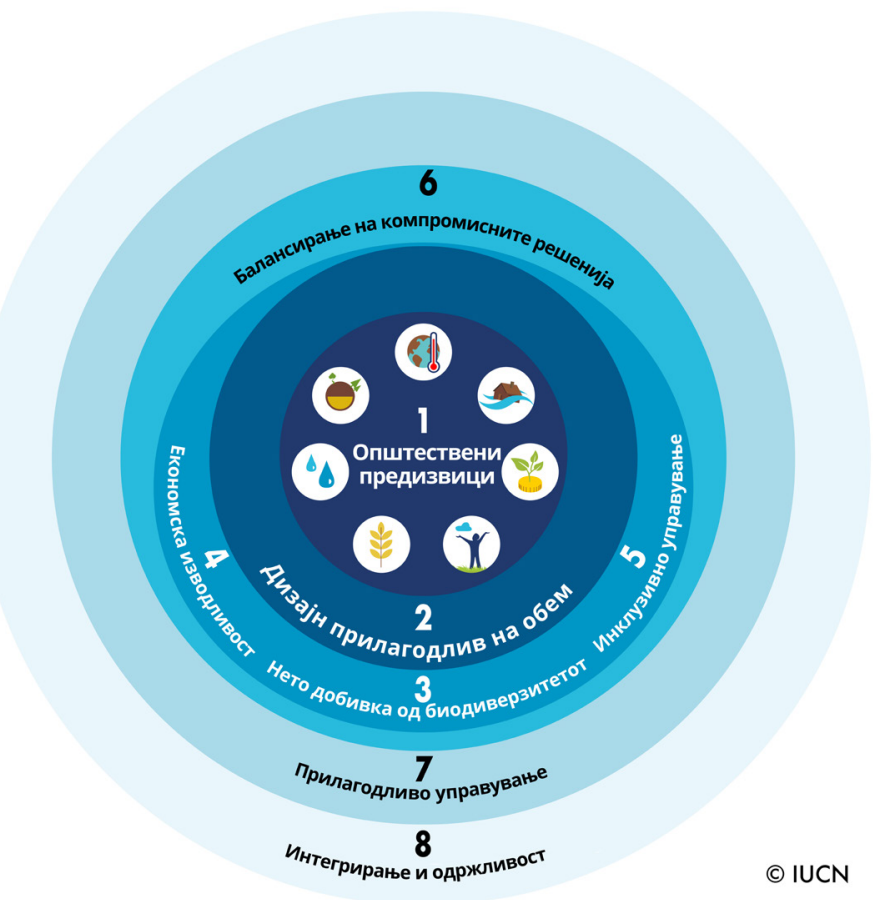

Слика 6: Сите осум критериуми што го сочинуваат Глобалниот стандард на IUCN за Р3П се меѓусебно поврзани. (৫ IUCN) на ниво на конкретна локација или со помал обем, согледувањата на поголем сразмер и обем може во голема мера да влијаат врз робусноста и трајноста на решението, дури и по неговото спроведување.

Со критериумите 3, 4 и 5 сеутврдуваат процесите што може да ги подобрат шансите за позитивен исход за биодиверзитетот, општеството и економијата. Меѓтта, со цел да се постигнат овие три критериуми во однос на непосредните, краткорочните и долгорочните исходи, треба да се утврдат и да се подготват компромисни решенија, коишто директно се разгледуваат во шестиот критериум, со цел на ова прашање да му се овозможи поголема видливост и важност. Процесите за донесување одлуки за какви било компромисни мерки мора да бидат транспарентни и правични и би можеле да бидат во рамките на контекстот на еден или повеќе критериуми од критериумите 3, 4 и 5. Покрај тоа, начелата на приспособливо управување поддржани од теоријата на промена и процесите на повторливо учење, во согласност со Критериумот 7, исто така може да го подобрат успехот на РЗП. Критериумот 8 се фокусира врз процесите за интегрирање на РЗП во просторен и временски сразмер, каде што активностите и влијанијата може да се одржат и надвор од самостојните проекти, со цел целосно искористување на потенцијалот на природата како алатка за изнаоѓање решенија за општествените предизвици.

Подолу се дадени упатства за осумте критериуми на Стандардот за РЗП и нивните основни показатели. Во упатствата се опишани елементите на она што претставува издржано РЗП и исто така се утврдува каде различните критериуми и показатели се меѓусебно поврзани. 


\section{Критериум 1: Со РЗП ефективно се решаваат општествените предизвици}

РЗП треба да бидат дизајнирани на начин на којшто ефективно и ефикасно ќе се решат конкретните општествени предизвици. Тука се вклучува приспособувањето и ублажувањето кон климатските промени, намалувањето на ризиците од катастрофи, деградацијата на екосистемите и загубата на биодиверзитетот, човековото здравје, социоекономскиот развој, достапноста на храната и водата. Трите главни видови на делотворни активности за зачувување на природата може да се користат (поединечно или во комбинација) со цел решавање на општествените предизвици зачувување преку заштита, обнова и активности на обновата, како и одржливо искористување. Дизајнот има за цел постигнување конкретни резултати, коишто директно и експлицитно се насочени кон општествените предизвици и придонесуваат за исполнување на општествените потреби, притоа одржувајќи ги функциите на екосистемите.

Пред почетокот на секоја интервенција, прво треба да се разгледаат превладувачките економски и еколошки услови. Тоа е важно со цел да може соодветно да се процени и целосно да се разбере видот на предизвикот којшто се решава и соодветноста на предложеното РЗП, како и да се измерат подобрувањата по извесен период. Основните параметри може да се состојат од анализа на ситуацијата, поддржано со објавена и/или т.н. сива литература. Исто така, основните параметри треба да се развијат во консултација со релевантните заинтересирани страни, идните корисници и останатите чинители, како што се владините тела, компаниите од приватниот сектор, локалните академици и научници со експертиза во областа на климата и екологијата на дадената локација, како и поднационалните власти со конкретна надлежност за дадената целна локација.

Иако РЗП се фокусираат врз решавање на општествените предизвици, дефинираните активности треба исто така да имаат за цел одржување и подобрување на екосистемските услуги, притоа одржувајќи ја структурата на екосистемите, нивната функција и состав (видете го Критериум3). Натојначинсезачувуваинтегритетоти стабилноста на еколошките системи и се подобрува долгорочната делотворност на РЗП во однос на решавањето на општествените предизвици. Едно РЗП што ја поедноставува структурата, функцијата и составот на еден екосистем ја намалува отпорноста и иако има одредени краткотрајни резултати, најпосле ќе колабира. Холистичките пристапи кон повеќегодишно траење имаат најдобра шанса за успех.

\section{K-1.1 Се врши приоритизирање на најнеодложните општествени предизвици за имателите на права и корисниците}

Иако РЗП може да генерираат повеќекратни придобивки за голем број општествени предизвици, интервенциите на РзП треба да соодветствуваат на најмалку еден (или повеќе) конкретни општествени предизвици.

При утврдувањето на општествените предизвици мора да се применува транспарентен и инклузивен процес (Критериум 5). Тоа се должи на фактот дека она што може да се смета за приоритетен предизвик од страна на надворешните заинтересирани страни може да не се смета за таков од страна на локалното население и обратно. Според тоа, процесите опишани во критериумите 5 и 7 треба да служат како основа за носење на одлуките. Исто така, важно е да се разбере и да се признае дека, поради останатите меѓусебно поврзани влијанија на општествените предизвици врз локалните заинтересирани страни, решавањето на даден општествен предизвик може да наложи решавање на друг предизвик. 
На пример, во некои заедници, невозможно е да се работи врз долгорочното влијание на климатските промени доколку заедниците немаат капацитет да се справат со сезонските катастрофи или да обезбедат безбедно место за живеење. Од друга страна, пак, доколку општествените и културолошките предизвици не се решат соодветно, како што се проблемите со вработувањето или поседувањето земјиште, ќе биде тешко да се постигнат пресвртните точки. Потребен е пристап на теоријата на промената со цел да се овозможи трансформациска промена што ќе трае и за наредните генерации. Упатувањата и алатките за тоа како да се развие теоријата на промената ќе бидат достапни како дополнителна информација кон овој Стандард.

\section{К-1.2 Разгледаните општествени предизвици се јасно разбрани и документирани}

Со интервенциите на Р3П треба да се решат општествените прашања коишто директно влијаат врз конкретна група луѓе (на пример, РзП за контрола на крајбрежната ерозија која загрозува одредена конкретна општина) или индиректно влијаат врз општеството како целина (на пример, РЗП дизајнирано за врзување јаглерод како опција за ублажување на климатските промени). Меѓутоа, дадена интервенција на едно РЗП во однос на еден конкретен општествен предизвик честопати има повеќекратни економски придобивки и, онаму каде што е соодветно, општествените предизвици што се решаваат со овие дополнителни придобивки треба да се опишат и да се документираат.

Исто така, не сите интервенции за зачувување или обновување на природата може автоматски да се сметаат за РЗП. Иако конзервациските интервенции може (директно или индиректно) да генерираат дополнителни општествени придобивки, голем дел од нив не се изречно дизајнирани или управувани за продуцирање такви придобивки. За една постојна конзервациска интервенција да биде проширена или претворена во РзП, потребно е менување на планот за надлежност и управување со цел да одговара на критериумите и целите на РЗП со воспоставување на потребните основни параметри со цел да се измерат и да се докажат испорачаните резултати. Особено, трансформацијата на конзервациското дејство би требало да се води врз основа на Критериумот 7 (Приспособливо управување) за да може да се смета за интервенција со Р3П.

\section{К-1.3 Утврдени се исходите за човековата благосостојба што произлегуваат од РЗП и за нив се определени споредбени критериуми со коишто периодично се оценуваат}

Потребно е да се развијат цели со цел дадената интервенција да даде придобивки за човековата благосостојба (во Поимникот е дадена дефиницијата за човековата благосостојба). Тоа е релевантно при диференцијацијата помеѓу конзервациските активности и РзП (Показател 1.1). Идеално, треба да се развијат целите и за спроведувањето, и за влијанието на интервенцијата. Додека целосното влијание на РЗП може да се реализира и надвор од временската рамка на интервенцијата, може да се развијат индикативни цели или клучни фази. Таквите цели или клучни фази би можеле да претставуваат стимулации за долгорочни вложувања во одржувањето на РзП и би биле корисни за долгорочен мониторинг на интервенцијата. 


\section{Критериум 2: Дизајнирањето на РЗП зависи од обемот}

Добриот дизајн на РЗП е свесен и ги зема предвид интеракциите што се случуваат во различните општествени и еколошки обеми во рамките на даден копнен предел или приморски предел - на пример, сезонското движење на сточарска заедница или сезонската надворешна миграција на млади мажи од рурални заедници за да работат во оддалечен град, или прилив на средства од членови од семејството што живеат подалеку. Доколку не се препознаат при дизајнирањето на проектите, интеракциите во рамките на различните обеми може да доведат до несоодветни или погрешно позиционирани активности, удвојување, конфликти и неуспех на проектите.

Важно е да се разбере како се поставени различните екосистеми во исто подрачје (предел) и како стапуваат во меѓусебна интеракција. Во секоја фаза од развојот и спроведувањето на РЗП, треба да се земе предвид поширокиот копнен/ приморски предел.

Р3П мора да се разгледуваат во даден обем на копнен/приморски предел поради тоа што екосистемите се засегнати и трпат дејства на пошироки копнени и приморски предели во коишто се вметнати и не може да се управуваат во изолација. Исто така, поради тоа што одредени добра и услуги на екосистемите се генерираат на ниво на копнените или приморските предели, активностите на РЗП мора стратегиски да се распоредат во рамките на поголеми копнени/ приморски предели.

Всушност, управувањето со еколошките процеси на ниво на предел - на пример, рециклирањето на хранливи материи - може да биде исто толку важно колку и управните одлуки донесени на ниво на локацијата на интервенција, особено доколку обезбедувањето екосистемски услуги е важна цел.
Споредтоа, долгорочното оценување, планирање, спроведување и мониторинг на активностите наменети да влијаат врз екосистемските добра и услуги од коишто има корист поширокото општество (вода, ублажување и приспособување кон климатските промени итн.) налагаат пристапи на ниво на копнениот/приморскиот предел и интегрирано спроведување и следење мерки специфични за локацијата. Поради таквите причини, во секоја фаза од развојот и спроведувањето на РЗП, мора да се земе предвид поголемиот копнен/приморски предел, како што е случај и со различните општествени и економски процеси коишто се одвиваат на таквите нивоа.

\section{К-2.1 Со дизајнот за РЗП се препознаваат и се обезбедува одговор на интеракциите меѓу економијата, општеството и екосистемите}

Сите интервенции, вклучувајќи ги и оние што се случуваат на поединечни локации или мали просторни обеми, треба да се развијат во контекст на големи копнени/приморски предели преку планирање на копнените/приморските предели, со цел активностите да се стратешки и да ги максимизираат придобивките за луѓето и екосистемите, притоа минимизирајќи ги негативните влијанија врз соседните екосистеми и човековата популација. Спроведувањето на иновативни РЗП во мал обем претставува основа за сразмерно зголемување, поради тоа што засегнатите страни во копнениот/приморскиот предел учат и применуваат нови практики иницирани од оние што се подготвени да се обидат со нешто ново. Контекстот на поголемите копнени/приморски предели вклучува еколошки, економски и социокултурни перспективи.

Наместо да се фокусира врз конкретен екосистем или збир на засегнати страни, со обемот на 
копнениот/приморскиот предел се разгледува како екосистемите и нивите функции се поврзани со вредностите, правата и придобивките на различните заинтересирани страни. Планирањето и носењето одлуки за РзП треба секогаш да се преземаат земајќи го предвид обемот на копнениот/приморскиот предел и со разбирање на импликациите на интервенциите на ниво на копнениот/приморскиот предел. Ваквите согледувања би можеле да им помогнат на практичарите што работат на РЗП да ги интегрираат различните потреби, различните секторски планови, програми и политики и да ја поддржат употребата на соодветни традиционални практики за спроведување во еден единствен просторен контекст којшто ги разгледува компромисните мерки, опциите и сценаријата. Таквите согледувања на ниво на копнениот/приморскиот предел не само што ќе вклучуваат мерки за дејства специфични за локацијата, туку исто така и за кумулативни влијанија меѓу локациите и различните засегнати страни.

Поради тоа што интеракциите помеѓу луѓето и природата се сложени и непредвидливи, дизајнирањето на РЗП може да се заснова врз едноставен квалитативен модел развиен во рамкинапартиципативенпроцес. Обично, тука би било вклучено идентификување на примарните интеракции меѓу засегнатите страни и начинот на којшто тие го користат земјиштето, интеракциите помеѓу ваквите групи на засегнати страни и самиот копнен или приморски предел, како и интеракциите помеѓу копнениот/приморскиот предел и надлежните политики и регулаторни аранжмани, вклучувајќи ги националните закони и политики. Овој едноставен модел на системи може да служи како основа за партиципативен развој на идните сценарија што го насочуваат процесот на донесување одлуки и овозможуваат соодветна интеграција на прашањата поврзани со критериумите 3, 4, 6 и 8.
Разбирањето на влијанието на интеракциите во рамките на хиерархиските обеми (и во рамките и помеѓу институциите кои учествуваат во РЗП) има важни импликации врз управувањето и разгледувањето на начинот на којшто постојните институции (формални и неформални) може да ги поддржат или да ги попречат алтернативните дизајни на РЗП.

\section{К-2.2 Дизајнот за РЗП е интегриран со другите комплементарни интервенции и бара синергии во рамките на секторите}

Р3П може да се спроведат поединечно, иако вообичаено тие се дел од еден интегриран пакет што вклучува други видови решенијапотребниза решавање на дадени општествени предизвици (на пр. технолошки и инженерски решенија, финансиски инструменти). Синергиите на РЗП со останатите видови решенија би можеле изречно да се испланираат. Важно е сите придонеси да имаат солидна научна основа и во нив да се инкорпорира интегративен пристап кон мониторингот како дел од дизајнот.

Врските помеѓу големиот број сектори со цел проширување на опсегот на решението на општествените предизвици може да се идентификува со цел да се поддржат синергиите меѓу различните решенија. Таквите заеднички пристапи ја подобруваат сопственоста на пристапот, го намалуваат ризикот од негативни несакани последици и го олеснуваат целокупното насочување на РЗП во политиките и секторите. При планирањето на РЗП, важно е активно да се бараат потенцијалните синергии со различните сектори (на пример, земјоделство, шумарство, водни ресурси, здравје итн.) што би можеле да придонесат за РЗП, за решавање на егзистенцијалните потребни и за подобрување на квалитетот на животната средина. Некои илустративни примери за таквите врски би 
можеле да вклучуваат инкорпорирање во РЗП на: а) секторите на земјоделско осигурување или осигурување на земјоделски култури, со цел подобро решавањенапроблемотсо достапноста на храна; б) здравствениот сектор, за подобро решавање на проблемите со човековото здравје во урбаните подрачја; в) инфраструктурата, со цел решавање на ризиците од катастрофи во случај на поплавување на крајбрежните области (преку комбинација од заштитни мангрови шуми и заштитни насипи).

\section{К-2.3 Во дизајнот за РЗП се вградува утврдување на ризиците и управувањето со ризиците надвор од местата на интервенција}

Кредибилните процеси на дизајнирање налагаат да се изврши проценка на влијанието на општествените и еколошките процеси, како и ризикот од несакани промени на системот поради настанувањето на надворешен настан (на пример, природна опасност) и како тоа може да влијае врз предвидениот исход од интервенцијата. Ова посебно важи за негативните влијанија што потекнуваат надвор од границите на интервенцијата.

Во оценката на ризиците исто така ќе се земе предвид и потенцијалот за поголема ранливост на одредени засегнати страни како непосакувана последица од дизајнот на интервенцијата. Ова е важно во случај на РЗП каде што повеќе извори би можеле да влијаат врз долгорочното здравје и интегритет на основните екосистемски услуги. Раното делување, како што е оценката на ризиците и влијанијата, како и проактивното управување со заканите, навистина може суштински да влијаат врз успешноста или неуспешноста на дадено РЗП. Основните клучни прашања може да се одговорат преку оценката на ранливоста и отпорноста, како на пример:

- Дали постојат конфликтни национални, регионални или локални политики коишто би можело негативно да влијаат врз управните цели на РЗП на предметниот социоеколошки систем?

- Дали постојат конфликтни тврдења во однос на социоеколошките системи и обезбедените услуги што би служеле како основа за РЗП?

- Дали во соседните подрачја или, пак, низводно се забележани практики на користење на земјиштето што би ја намалиле делотворноста на РЗП?

- Дали дизајнот на РЗП е доволно робустен за да може да ги апсорбира предвидените економски, демографски и климатски промени?

- Дали самото РЗП претставува потенцијален ризик или, пак, дополнителен притисок врз поддршката на екосистемите (на пример, ризик од внесување или ширење на инвазивни видови)? 


\section{Критериум 3: РЗП резултира во нето-добивка за биодиверзитетот и интегритетот на екосистемот}

Со тековнатакризасо биодиверзитетот, несамо што на ретките видови им се заканува изумирање, туку и сериозно се деградираат голем број екосистеми, при што се нарушува и здравјето на планетата и поширокото човеково здравје. Без оглед на тоа кои општествени предизвици се цел, сите РЗП мора да имаат нето позитивно влијание врз биодиверзитетот; со други зборови, биолошката разновидност и еколошкиот интегритет на местото на интервенција и неговата околина треба да се подобрат како резултат од РЗП.

Целта на Р3П треба да биде зачувување или обновување на интегритетот на екосистемот и избегнување на понатамошно поедноставување на екосистемот (како што е замена на природно мешаните шумски предели со плантажи со дрвја-монокултури). Иако биодиверзитетот (види целосна дефиниција во Поимникот) претставува клучна компонента за еколошкиот интегритет, другите еднакво важни компоненти ја вклучуваат структурата и функцијата на екосистемите и копнените/приморските предели, како и поврзаноста. Покрај тоа, РЗП зависи од еколошката состојба на придружните екосистеми; поради тоа, во интерес на практичарот на РЗП е да осигури дека мерките за спроведувањето, во најмала мерка, ќе го одржат еколошкиот интегритет на целната област во подолг рок. Важно е конзервациските цели да бидат утврдени од страна на предлагачите на РЗП и да бидат инкорпорирани во плановите за спроведување, како и дека напредокот е земен предвидво текот на следењето на спроведувањето, а притоа да не се занемарат општествените предизвици коишто РЗП има за цел да ги разреши.

Разумно е практичарите на РЗП периодично да ги оценуваат негативните влијанија во целните и соседните екосистеми. Во оперативниот план за РзП треба да има детален преглед заснован врз докази на потенцијалните ризици и на влијанијата на главните активности на РЗП во однос на областа на биодиверзитетот. Покрај тоа, првата фаза во планирањето на РЗП треба да го претставува разбирањето на основната состојба на целниот копнен/приморски предел во однос на биодиверзитетот, составот, структурата, функцијата, поврзаноста и надворешнитезакани. Оваа основна состојба обезбедува информации за степенот на деградација и може да се употреби за да се утврдат специфичните цели на РЗП, како и споредбениот критериум за утврдување на ефикасноста и влијанијата. Поради тоа што сите екосистеми и копнени/приморски предели - вклучително и оние без или со минимална деградација - се динамични, степенот на деградација не треба да се оценува врз основа на историскиот екосистем или копнениот/ приморскиот предел, туку врз основа на состојбата во која системот би се наоѓал денес ако немало деградација. Ова може да се карактеризира со креирање модели од постојните референтни места или копнени/приморски предели, теоретските информации или традиционалното знаење. Анализите и собирањето податоци може да бидат скапи. Сепак, има потреба од основни параметри за да се карактеризираат клучните компоненти на еколошкиот интегритет и да се утврдат тековните двигатели за деградацијата.

\section{К-3.1 Активностите на РЗП директно одговараат на оценката заснована врз докази на актуелната состојба на екосистемот и превладувачките двигатели на деградацијата и загубата}

Анализата и собирањето податоци се скапи, така што секогаш постои ризик дека практичарите на РЗП ќе ги ограничат основните оценки изречно на екосистемските услуги од интерес (на пример, со иницијативата за врзување јаглерод 
преку подобрено управување со тресетишта се оценува само потенцијалот за врзување јаглерод). Сепак, поради тоа што обезбедувањето на екосистемските услуги е нарушено од интегритетот и состојбата на самиот екосистем и имајќи предвид дека еден од клучните атрибути на РЗП се состои во тоа што РЗП придонесува и кон зачувување на биолошката разновидност, пожелно е основните параметри да бидат доволни за да се насочуваат овие видови раководни одлуки во текот на спроведувањето.

Основните информации за основните параметри треба да го вклучуваат следново како минимум:

1. Структурните информации, вклучително и трофичката динамика и вегетациските слоеви и нивнатапросторна распространетост во рамките наекосистемитеипросторнатараспространетост (и шемите на распространетост) на клучните видови екосистеми во рамките на копнените/ приморските предели, во согласност со потребниот обем во областа од интерес и нивниот тековен статус на заштита;

2. Составот на видовите, вклучително и бројноста на видовите од клучните таксономски групи (на пример, васкуларни растенија, цицачи, птици и почвени микроорганизми) и тековниот статус на заштита на видовите (ризик од изумирање);

3. Информациите за клучните екосистемски функции (на пример, стапки на продуктивност, проток на вода на хранливи материи и биотички интеракции);

4. Клучните аспекти на физичката средина (на пример, количество и квалитет на водата и информации за физичките и хемиските својства на почвата и другите супстрати);

5. Поврзаноста, вклучувајќи ги и коридорите со природна или полуприродна вегетација низ копнените/приморските предели со коишто се поврзуваат заштитените и полузаштитените области и другите засолништа (рефугии) за биодиверзитетот и коишто овозможуваат размена на пропагули, вода и материјали меѓу екосистемите;

6. Надворешните закани за екосистемот или копнените/приморските предели и ризикот од колабирање на екосистемите, кога е возможно според утврденото од страна на Црвената листа на IUCN на засегнати видови ${ }^{\top м}$ и Црвената листа на екосистеми;

7. Постојните или тековните интервенции за заштита за видовите и екосистемите во ризик во копнениот/приморскиот предел.

Основната оценка треба да се користи за утврдување на степенот на деградација и дизајнирање на проектните цели, како и за да се разберат промените што РЗП ги произведува со текот на времето, коишто потоа може да се употребат за целите за управување, вклучувајќи го и приспособувањето на интервенциите со РЗП за да се намалат негативните исходи. За ова е потребно проценетите променливи и единицата за анализа да бидат слични или идентични во однос на основната анализа. Потребно е редовно следење за да се оценат подобрувањата на интегритетот на екосистемот и капацитетот за обезбедување на посакуваните услуги.

\section{К-3.2 Јасните и мерливи конзервациски резултати за биодиверзитетот се утврдени, определени се споредбените критериуми и тие периодично се оценуваат}

Имајќи предвид дека РЗП зависат од здравјето и состојбата на придружните екосистеми, во интерес на практичарот е да осигури дека со мерките за спроведување барем се одржува, а иделно се подобрува, еколошкиот интегритет и разновидноста на видовите во целната област во подолг рок. Опфатот и опциите за таквите подобрувања се специфични во однос 
на контекстот, зависат од договорот со другите заинтересирани страни, од националните и поднационалните политики и достапните ресурси. Во некои ситуации, РЗП може да вклучат активности за еколошка обнова со коишто се отстранува деградацијата и се овозможува системот да се врати во состојбата во која би бил без деградацијата. Во други ситуации, целта на РЗП може да биде само да се диверзифицира составот на видовите на определени места или да се подобри обезбедувањето на само еден дел од клучните екосистемски функции. Важно е конзервациските цели да се утврдени и вградени во спроведувањето, како и дека ефикасноста и влијанијата (вклучително и непредвидените последици) се определени преку следење, при што нема да се занемари општествениот предизвик којшто е целта на РЗП.

Како минимум, РЗП треба да го вклучуваат следното, за секоја раководна цел поврзана со зачувувањето и обновувањето на биолошката разновидност и еколошкиот интегритет:

1. Посебни мерливи променливи поврзани со целта за управување (на пример, број на видови/ ha, \% покривка со крошни);:

2. Активност(например, зголемување, намалување, одржување);

3. Количество (на пример, 50 \%);

4. Временски период (на пример, 5 години).

\section{К-3.3 Следењето (мониторингот) вклучува периодични проценки на непосакуваните негативни последици врз природата што произлегуваат од РЗП}

Планот за спроведување на програмата за мониторинг за утврдување на ефикасноста и влијанијата (вклучувајќи ги и негативните влијанија) на РзП треба да се изготви во исто време со изготвувањето на планот за РЗП.
Екосистемите се сложени и динамични. Иако робусниот процес за планирање (Критериум 2) ќе помогне во предвидувањето и разрешувањето на негативните секундарни влијанија, секогаш има ризик од непредвидени исходи кога се работи со природни системи и процеси. Затоа е пожелно практичарите на РЗП периодично да вршат ревидирање во однос на негативните влијанија во целните и соседните екосистеми. За таа цел, во оперативниот план за РЗП треба детално да се наведе преглед заснован врз докази на потенцијалните ризици и влијанија од главните интервенции со РЗП. Ова треба да вклучи утврдена фреквенција на следење и рамка за одговор ако се забележат негативни секундарни влијанија.

Во планот за следење и евалуација мора да се вклучи следното:

1. Износ и извори на финансирање за секоја компонента од програмата за следење (детално прикажани подолу);

2. Дизајн за собирање податоци, вклучувајќи ги и променливите што треба да се оценат, методот за собирање податоци, потребната репликација за да се утврдат влијанијата од раководните интервенции, фреквенцијата и времетраењето на следењето;

3. Видовите анализа што ќе се користат за проценка на влијанијата од управувањето;

4. Локација и протоколи за управување и креирање постојана архива на податоци;

5. Начинот на којшто ќе се споделуваат научените лекции.

\section{К-3.4 Можностите за јакнење на интегритетот на екосистемот и неговата поврзаност се утврдени и вградени во стратегијата за РЗП}

Поврзаноста на екосистемот се однесува на двонасочниот проток на биотичките (т.е. живите) компоненти на екосистемите, кои инаку би биле одвоени во копнениот/приморскиот 
предел со физички бариери. Придонесувањето кон подобрената поврзаност на екосистемите може често да претставува цел за зачувување која релативно лесно може да се олесни со РЗП. Опсегот во којшто се разгледува поврзаноста во планирањето зависи од целите што се поставени за интервенцијата со РЗП.

Исто така, има силна социјална перспектива за поврзаноста на екосистемот, и од тој аспект, дел од најдобрите можности за интервенциите со Р3П се однесуваат на урбаната побарувачка за зелени простори, не само за рекреативни и надворешни образовни можности, туку и за јавното здравје и намалувањето на честичките и прашината. Поврзаноста меѓу урбаните екосистеми и внатрешноста е многу добар пример за развојот на зелени простори во урбаните области.

Други примери за начините на коишто РЗП може да ја подобрат поврзаноста вклучуваат планирани коридори кои поврзуваат мали засолништа (рефугии) на биодиверзитетот, како што се живата ограда, водните живеалишта и шумските парцели во инаку изменети екосистеми, за да се овозможи движењето на видовите во даден предел; или зачувување на поврзаноста меѓу изворишните предели и урбаните области со коишто се обезбедуваат одржливи залихи вода за жителите. РЗП мора да бидат дизајнирани, спроведени иследени, имајки ја притоа предвид поврзаноста и нејзиното влијание врз интегритетот на екосистемот. 


\section{Критериум 4: РЗП се економски одржливи}

Еден од предизвиците со коишто голем број практичари на РЗП денес се соочуваат е недостигот од економско или финансиско планирање и долгорочни ресурси. Голем број интервенции прават грешка и вложуваат рани значителни инвестиции без да ја земат предвид економската и финансиската одржливост надвор од рамката за интервенција. Не само што со ова се зголемува ризикот од неуспех на РЗП, туку и не се искористуваат можностите коишто РЗП ги нуди во однос на одржливиот економски развој. На пример, креирањето зелени работни места и одржливи основни средства за живот може да се интегрираат во рамките на опфатот на интервенцијата со РЗП, за да се обезбедат стимулации за понатамошно влијание.

За РЗП да бидат одржливи, потребно е да има силен економски аспект (покрај другите два столбови за одржлив развој - животна средина и социјални аспекти). Во спротивно, ќе се соочиме со ризикот од спроведување кое еограничено на рокот натраење на проектот (на пример, пет години), при што, по завршувањето, решението и повеќекратните придобивки што се обезбедени се намалуваат и, потенцијално, престануваат да постојат, па дури и може да ги остават копнениот/приморскиот предел во полоша состојба од претходно. Покрај тоа, РЗП не функционираат во вакуум во однос на финансиите, бидејќи мора да има определено ниво на кохезивност и интегрирање со финансиските институции и структурите за мотивација. Потребно е разбирање на тоа дали економската политика и финансиските структури се комплементарни за да се осигури дека РЗП го нудат својот широк опсег на придобивки за природата и луѓето.

Природата е во основата на нашата економија и општество преку производството на придобивки за луѓето, директно (на пример, храна, дрво и влакна) и индиректно (на пример, циклус на хранливи материи, создавање почва, опрашување).
Добрата и услугите што се обезбедуваат за луѓето од природниот капитал вклучуваат опсег на општествени придобивки и придобивки од животната средина вклучувајќи чист воздух и вода, ублажување на климатските промени и приспособување кон нив, храна, енергија, места за живеење, материјали за производи, рекреација и заштита од непогоди. Иако за дел од овие придобивки се вршат трансакции и се оценуваат преку пазарите, голем број придобивки од природата се непазарни добра и услуги, вклучувајќи и некои кои навидум се достапни бесплатно. Кога се евалуираат РЗП, клучен предизвик е да се инкорпорираат нивните повеќекратни придобивки од една заедничка економска евалуациска рамка.

Централните пристапи за инкорпорирање на економските аспекти вклучуваат ефективност во однос на трошоците и оценка на трошоците и придобивките. Кога се ефективни во однос на трошоците, РЗП го постигнуваат пакетот на посакувани резултати (на пример, врзување на CO2, заштита од поплави, филтрација на вода и зачувување на биодиверзитетот) по трошок којшто е понизок или споредлив со оној на другите можни решенија за истите општествени предизвици. За оценката на ефективноста на трошоците не е потребно да се користи заедничка валута, што помага во инкорпорирањето на немонетарните придобивки, а ги ограничува опциите што се достапни за споредба со различните исходи од придобивките. Оценката со повеќе критериуми може да ја надополни оценката на ефективноста на трошоците преку собирање на различните крајни точки за придобивките во една заедничка рамка за евалуација и одлуки.

Во анализата на трошоците и придобивките се интегрираат повеќекратни исходи од придобивки, приватни и општествени, со тоа што тие се споредливи преку употребата на заедничка валута. Кога сите придобивки може да се монетизираат, 
анализата на трошоците и придобивките ја надминува ефективноста на трошоците и се евалуираат не само трошоците за постигнување конкретен исход од придобивките (економичност) туку и се определува кое ниво на инвестиции во РЗП пред сѐ се гарантира (придобивките ги надминуваат трошоците)

\section{К-4.1 Директните и индиректните придобивки и трошоци поврзани со РЗП, кој плаќа и кој има придобивки, се утврдени и документирани}

Најосновното барање за да се разберат економските аспекти на РЗП вклучува идентификација и документирање на сите видови добиени придобивки (финансиски и нефинансиски; економски и неекономски), кој ги добива, колкави се трошоците за обезбедување и кој ги сноси тие трошоци. Придобивките и трошоците може да се оценат од неекономски или економски аспект (на пример, намалени здравствени трошоци), или двете. Земањето предвид на пазарните и непазарните аспекти на РЗП е клучно за да се обезбеди сеопфатна оценка, за да се утврди кој е плаќачот, кој ќе има придобивки и кој е извршителот. На овој начин се обезбедуваат информации за аспектот поврзан со компромисните решенија во рамките на шестиот критериум (Показател 6.1).

\section{К-4.2 Се обезбедува студија за економичност за да се поддржи избирањето на РЗП, вклучително и веројатното влијание од кои било релевантни прописи и субвенции}

Аналитичката рамка може да биде основна студија за економичност, оценка на трошоците и придобивките или анализа со повеќе критериуми. Има неколку методи и алатки што се корисни за студиите за економичност и, во најмал степен, обидот за тоа да се направи значително ќе помогне во обезбедувањето информации за Критериум 6 за компромисните решенија.

\section{K-4.3 Ефективноста на дизајнот за РЗП се оправдува во однос на достапните алтернативни решенија, притоа земајќи ги предвид кои било поврзани надворешни фактори}

Основната цел на РЗП е ефективно да се разреши најмалку еден општествен предизвик на начин којшто е економски одржлив. За да се утврди најефективното и најдостапното решение, мора да се земат предвид алтернативни решенија. Алтернативните решенија може да бидат чисто технолошки или инженерски, структурни решенија (сиви решенија). Со споредбата на различните решенија може да се обезбедат информации за најефективниот начин за идното разрешување на општествените предизвици. Овој показател е цврсто поврзан со претходниот Показател 4.2.

\section{К-4.4 Во дизајнот за РЗП се зема предвид портфолио на опции за ресурси како што се обврските засновани на пазарот, јавниот сектор, доброволните обврски и активностите за поддршка на регулаторната усогласеност}

За да се осигури одржливоста на РЗП, потребно е обезбедување соодветни ресурси. Ова е случајот без оглед на тоа дали интервенцијата е водена од добивка или не се заснова врз добивка. Кај вториот случај, обезбедувањето на ресурси може прво да се потпира на грант, но треба да се земат предвид и средства за идни ресурси надвор од временската рамка за интервенциската активност. Во моментов, со растот на барањето за РЗП се зголемуваат и опциите за обезбедување ресурси, а особено 
иновативното финансирање, како што е мешовитото финансирање. Мешовитото финансирање претставува „стратешка употреба на развојните финансии за обезбедување дополнителни финансиски средства за одржлив развој во земјите во развој" (ОЕЦД, 2020). За да се осигури дека РЗП го нуди најефективното решение за општествените предизвици во секој случај, потребно е да се земат предвид различни опции вклучувајќи ги, на пример, циркуларната економија, доброволните обврски, даночните шеми, зелените работни места и социјалното финансирање. Финансирањето на РЗП од страна на приватниот сектор преку корпоративната општествена одговорност (КОО) или добротворното финансирање нуди можности коишто исто така треба да се земат предвид.

\begin{abstract}
Долгорочниот деловен/финансиски план треба да се земе предвид заради решавање на економската/финансиската изводливост и пречките на РЗП. Во овој план се разгледува и надвор од рамките од фазата за планирање и првичното спроведување со поддршка од грант. Ако не се земат предвид долгорочните финансиски аспекти, краткорочните трошоци би можеле да ги надминат долгорочните придобивки. Можно е заклучокот од таа анализа да биде дека посакуваното решение тогаш не се смета за економски одржливо од временски аспект. Поради тоа, во планирањето треба да се земе предвид фазата на спроведување, а и да се вклучи степен на напредно размислување со горенаведениот критериум.
\end{abstract}




\section{Критериум 5: РЗП се засноваат врз инклузивни, транспарентни и зајакнувачки процеси на управување}

Соодветните процеси на управување се клучни за да се определат успешни резултати од РЗП за луѓето и за природата. Со еднакво учество, делење на овластувања, признавање и безбедност на правата и јасност на одговорностите, ќе се осигураат истовремени придобивки за луѓето и природата и на краткорочен и на долгорочен рок. Управувањето со интервенцијата со РЗП вклучува можности за вклученост во идентификацијата, одлучувањето, следењето и повратните информации и процесите за поднесување жалби од сите заинтересирани страни. Сите РзП треба да бидат со инклузивен пристап при утврдувањето и воспоставувањето на механизмите за управување и треба да ги признаваат и да ги почитуваат претходно постоечките културни практики и употребата на земјиштето онаму каде што е возможно во текот на животниот циклус на интервенцијата и по неговото завршување. Треба да се спроведе процес на ригорозно мапирање на заинтересираните страни за да се утврди опсегот на заинтересирани страни коишто ќе бидат засегнати од РЗП и на кој начин ќе бидат засегнати. Сите групи на заинтересирани страни треба да бидат застапени, а нивните удели во интервенцијата треба да се земат предвид при одлучувањето во врска со РзП. На тој начин може да се минимизира ризикот од маргинализирањето на определена група заинтересирани страни или, што е полошо, интервенцијата со РЗП негативно да влијае врз нив. Од друга страна, недостигот од таков инклузивен пристап ќе доведе до одлучување засновано врз ограничени, погрешни и тесни перспективи, што може да доведе до зголемени социјални и/или економски нееднаквости меѓу заинтересираните страни. Може да резултира во идни конфликти со незасегнатите заинтересирани страни коишто сметаат дека требало да бидат консултирани. Ова е можно особено поради инхерентните разлики во овластувањата или асиметријата меѓ заинтересираните страни коишто може да бидат вклучени или засегнати. Покрај тоа, поради недостигот од инклузивен пристап, може да се влошат ризиците истакнати во показателите
2.3 и 3.3 (непосакувана промена надвор од местото на интервенција и негативни последици) и да се ограничи степенот до којшто може да се практикува приспособливото управување.

Транспарентноста е, исто така, клучна за да се осигури дека ресурсите (финансиски, човечки и природни) се користат на објективен и ефикасен начин во корист на групата корисници коишто се збирно идентификувани и утврдени од страна на сите вклучени заинтересирани страни. Потребна е транспарентност во однос на надворешните чинители коишто може да ја предводат интервенцијата за локалните заинтересирани страни, а особено за локалните заедници да можат да ги разберат непосредните и долгорочните импликации од интервенциите со РЗП, без оглед дали се еколошки, економски или социјални (а особено кои било потенцијални негативни влијанија врз културните, локалните права и практики). Важно е сите заинтересирани страни да ги разберат и да имаат еднакви можности за да бидат дел од процесите за одлучување во однос на начинот на којшто може да бидат засегнати од таквите импликации, вклучително и кои било компромисни решенија што ќе треба да се донесат (Критериум 6) во спроведувањето на РЗП.

Исто така, Р3П треба да придонесат кон разрешувањето на структурните, емоционалните и управувачките нееднаквости коишто може да постојат, а особено оние коишто не им овозможуваат моќ на одлучување на најмаргинализираните. Ефективното управување помага да се избегнат конфликти и неуспешност на активноста за зачувување. Со употреба на алатките како што е Рамката за управување со природни ресурси (NRGF), може директно да се придонесе кон исполнувањето на Критериум 5, бидејќи тие се предвидени да го насочуваат дизајнирањето и спроведувањето на проектите со коишто се постигнува сеопфатно, конзистентно и систематско земање предвид на инклузијата, еднаквоста и правата. 
За да се постигне партиципативно, рамноправно, транспарентно и отчетно управување со интервенциите за РЗП, со пристапот треба да се зајакнат заинтересираните страни, а особено оние коишто можеби се сиромашни, помалку влијателни или маргинализирани, на почетокот од процесот, преку проактивно јакнење на капацитетите и споделување на знаењето.

Со јакнењето може да се обезбедат основите за подолгорочна сопственост, креирање на самодоволност и најпосле, одржливост, како и сразмерно зголемување на интервенцијата.

Комуникацијата и соработката се поефективни кога потребите и културите на публиката се признаени и разбрани. Онаму каде што е релевантно, би било особено важно да се осигури дека мултиетничките заедници ги планираат и ги распределуваат ресурсите за превод и толкување на придонесите така што сите присутни ќе бидат запознаени и ќе го разберат она што сите го зборуваат.

\section{К-5.1 Дефинираниот и целосно утврдениот механизам за решавање жалби и добивање повратни информации е достапен за сите заинтересирани страни пред да започне интервенцијата со РЗП}

Механизмот за поднесување жалби или решавање спорови треба да се усвои рано, идеално при планирањето на интервенцијата, без оглед дали е формален правен процес или неформален систем надвор од правното подрачје, и потребно е да има утврдени постапки, улоги и правила за примање и одлучување за таквите интервенции. Ревидирањето на постојните механизми за правна заштита во меѓународното право за активностите за зачувување ја покажа важноста од вклучување контекстуално соодветни методи за постапување и правна заштита. Механизмот за поднесување жалби треба да биде легитимен, пристапен, предвидлив, правичен, транспарентен, компатибилен во однос на правата, приспособливо управуван и заснован врз соработка и дијалог.

\section{К-5.2 Учеството се заснова врз заемно почитување и рамноправност, без оглед на полот, возраста или општествениот статус и го почитува правото на домородните народи на слободна, претходна и информирана согласност (FPIC)}

Учествототребадабиденасочено коносигурување дека разновидното знаење, вештини и идеи обезбедуваат информации за спроведувањето и еволуцијата на интервенцијата, каде што заинтересираните страни имаат сопственост на РЗП и можат и самите да обезбедуваат збирни и континуирани активности по интервенцијата. Целосното учество е важно за успехот на интервенцијата. Пасивното учество, при кое определени групи заинтересирани страни може едноставно да бидат информирани за тоа што ќe се случи или што се случило, ќе ја намали робусноста на процесот. Слично на ова, учеството не може да претставува активност во која се извлекуваат информации од страна на една или повеќе групи заинтересирани страни, ниту пак може да се заснова врз принуда или стимулација со материјални добивки. Онаму каде што се засегнати домородните народи, мора особено да се следи начелото на слободна, претходна и информирана согласност (FPIC) во рамките на дизајнот и спроведувањето на РЗП, а другите групи заинтересирани страни може, исто така, да имаат придобивки од пристапите на FPIC.

\section{К-5.3 Заинтересираните страни што се под директно и индиректно влијание од РЗП се идентификувани и вклучени во сите процеси од интервенцијата на РЗП}

РЗП треба да овозможи активно учество на сите лица коишто може да бидат директно или индиректно засегнати од почетокот до крајот на интервенцијата. Со примена на робусната алатка за мапирање на заинтересираните страни, анализата на заинтересирани страни треба дасе 
спроведе со цел идентификување и вклучување на цел опсег на лица кои може да бидат засегнати од РЗП. Во процесот, исто така, треба да се идентификуваат заинтересираните страни кои може да бидат под негативно влијание и да се обезбедат можности за нивно јакнење, заедно со обезбедувањето правна заштита, за да се спречи нивната понатамошна маргинализација поради РЗП. Со механизмите за одлучување и спроведување на интервенцијата со РЗП, мора да се претстави и различноста и придонесот на засегнатите групи заинтересирани страни.

\section{К-5.4 Со процесите за одлучување се документираат и се одговара на правата и интересите на сите заинтересирани страни што учествуваат и што се засегнати}

Онаму каде што заинтересираните страни подлежат на нееднаквост, неправедност и маргинализација од аспект на нивните овластувања, социјална положба, култура или финансиска состојба, основните причини треба да се разберат и треба да се вложат сите напори за да се намалат или да се избегнат таквите нееднаквости колку што е можно повеќе. На тој начин се намалува веројатноста од конфликти. Во случај на потенцијални конфликти, тие се решаваат со преговори, при што се признаваат правата на заинтересираните страни во согласност со културните и општествените контексти и потребата од договор за намалување на ризикот од неуспех. На тој начин ќе се обезбедат информации за приспособливото управување со интервенцијата со РЗП бидејќи е невозможно да се предвидат и да се намалат сите влијанија и импликации од интервенцијата само преку процесот за планирање. Покрај тоа, ако конфликтите не може да се решат меѓу заинтересираните страни, потребно е да се користи механизам за поднесување жалби и правни лекови.

\section{K-5.5 Онаму каде што опсегот на РЗП излегува од правосудните граници, воспоставени се механизми за да се овозможи заедничко одлучување на заинтересираните страни во засегнатите надлежности}

Екосистемитечесто гинадминуваат политичкитеили административните граници. Поради тоа, важно е да се осигурат холистички пристапи што вклучуваат заинтересирани страни и институции надвор од границите на географскиот опсег на РЗП што се спроведуваат. Воспоставувањето колаборативни организации и правила, или надградување на постојните, е важно за интервенциите коишто вклучуваат интервенции што надминуваат граници како што се реки и миграторни видови. Таквите тела може да избегнат конфликтни управувачки цели во соседни надлежности кои се дел од истиот еколошки систем. Со несовпаѓањето на општествените и еколошките обеми се зголемува ризикот од неуспех, поради што во партиципативниот пристап кон управувањето треба изречно да се потврдат овие поврзувања (види и Критериум 2 за еколошкиот обем).

Онаму каде што е соодветно, за ефективните РЗП понекогаш може да биде потребна координација на прекуграничната или регионалната соработка. Во такви случаи ќе биде потребно да се обезбедат договориза соработка одрелевантните национални власти со коишто се обликува заедничката визија и конзистентниот пристап кон планирањето на РЗП, следењето, заедничкото одлучување и спроведување. Договорот треба да биде придружен со правен преглед за да се осигури усогласеност со релевантните меѓународни договори за соработка (т.е. дека националните власти коишто го спроведуваат го имаатпотребниотмандат и дека има воспоставена постапка за користење правни лекови која може да се користи во случај на спорови или непредвидени последици) и законите и прописите на различните вклучени надлежности. Често може да се побара од меѓувладина организација (MBO) да помогне за процесот. 


\section{Критериум 6: NРЗП рамноправно ги балансира компромисните решенија меѓу постигнувањето на нивните основни цели и континуираното обезбедување на повеќекратни придобивки}

Иако се очекува дека со поединечното РзП исклучиво ќе се приоритизира еден или повеќе општествени предизвици (Критериум 1), екосистемите коишто се поддржуваат ќе продолжат да обезбедуваат опсег на придобивки што се важни за општеството како целина (Критериум 3). Навистина, способноста истовремено да се обезбедат повеќекратни придобивки претставува главен атрибут на РЗП. Во определени случаи, „наслојувањето" на клучните придобивки (на пример, заштита на водата, врзување на јаглеродот и јавно здравје преку рекреација) претставува важен определувачки фактор за тоа дали РзП се економски одржливи (Критериум 4).

Сепак, овој основен атрибут на екосистемите може, исто така, да обезбеди предизвик за практичарот на РЗП. Со максимизирањето на РЗП се ризикува сразмерно намалување на клучните придобивки од екосистемите коишто се клучни за решавање на предметниот општествен предизвик. Спротивно, со максимизирањето на клучните придобивки од екосистемите речиси сигурно ќе се постигне намалувањенаквалитетотиколичеството надругите екосистемски придобивки. Таквите компромисни решенија често претставуваат инхерентна карактеристика на управувањето со природните ресурси и настануваат кога се фаворизира определена екосистемска услуга или преференции на заинтересираните страни (на пример, чиста вода за пиење) на сметка на други (на пример, земјоделско производство). Исто така, сите заинтересирани страни не се еднакво засегнати и РЗП треба да бидат исклучиви за тоа кои придобивки и чии трошоци ќе бидат разгледани. Некои компромисни решенија се резултат од намерни одлуки, додека другите настануваат без планирање или свесност за влијанијата. Компромисните решенија стануваат голем проблем кога истиот избор повеќепати се реплицира, така што исчезнуваат придобивките од важните екосистеми или настануваат на подоптимални нивоа во целиот копнен/приморски предел.

Сепак, со компромисните решенија може успешно да се управува ако соодветно се оценат веројатните последици, ако тие целосно се обелоденат и се утврдат од страна на најзасегнатите заинтересирани страни (види студија на случај за Критериум 6 во Дел І). Со објективното и транспарентно преговарање за компромисните решенија и компензацијата меѓ потенцијално засегнатите страни за каква било загуба како резултат од РЗП, вклучително и основните средства за живот, се обезбедува основата за успешни долгорочни резултати од РЗП. Клучно е да се потврди дека компромисните решенија имаат ограничувања, што значи дека ќе има потреба од заштитни мерки за да се осигури дека долгорочните стабилизирачки својства на услугите за регулација и поддршка на екосистемот не се надминати, како што е случајот со практиките за интензивно индустриско користење на земјиште. Од неодамна се достапни и алатки како што е алатката Вреднување на екосистемските услуги и компромисни решенија - inVEST (Sharp et al., 2020) и студии на случаи за лекции од управувањето со компромисните решенија. Ќе има достапна збирка од корисни студии на случаи и предложени алатки што го надополнуваат ова упатство.

\section{К-6.1 Потенцијалните трошоци и придобивки од поврзаните компромисни решенија за интервенцијата со РЗП се изречно потврдени и обезбедуваат информации за заштитните мерки и кои било соодветни корективни активности}

Практичарите на РЗП ги идентификуваат и ги документираат придобивките и трошоците за РЗП 
и кој ги добива и кој плаќа за нив (Критериум 4), и тие резултати се користат за активностите, како и за рамноправното делење на придобивките и трошоците меѓ заинтересираните страни. Таа анализа не треба да биде ограничена на фазата на планирање, тукутребада севградиво целиот животен циклус на РЗП, вклучително и во започнувањето, планирањето, извршувањето и завршувањето, притоа потврдувајќи дека интервенциите со РЗП може непрекинато да се спроведуваат.

Компромисните решенија имаат просторна, временска и реверзибилна димензија. Просторната димензија се однесува на тоа дали влијанијата од компромисните решенија се чувствуваат локално или на пооддалечена локација. Временската димензија се однесува на тоа дали влијанијата се случуваат брзо или бавно. Реверзибилноста ја изразува веројатноста дека нарушените екосистемски услуги може да се вратат во својата првична состојба ако престане настанот на нарушување. Покрај тоа, мора да се воспостават аранжмани за споделување на придобивките што се заеднички договорени за да се осигури еднакво балансирање на придобивките и компромисните решенија од политиките и инвестициите.

\section{К-6.2 Правата, користењето и пристапот до земјиштето и ресурсите, заедно со одговорностите на различните заинтересирани страни, се потврдени и се почитуваат}

Законските и употребните права на ранливите и маргинализираните групи треба да се почитуваат. Правата, употребата, одговорностите и отчетноста на групите заинтересирани страни мора да се анализираат и да се оценат со примена на соодветни алатки, со надградување на исходите од анализата или со мапирање на заинтересираните страни.

Особено, кога станува збор за домородни народи и локални заедници, мора да се користи слободна претходна и информирана согласност (FPIC) (усогласена со Критериум 5). Дополнително, сите заинтересирани страни не се еднакво засегнати, а РзП треба да имаат механизми за балансирање на компромисните решенија меѓу групите преку употреба на пристапи како што се транспарентноста, стимулациите и одржливите алтернативи.

\section{К-6.3 Воспоставените заштитни мерки периодично се ревидираат за да се осигури дека заеднички договорените ограничувања за компромисните решенија се почитуваат и не ги дестабилизираат сите РЗП}

Голем број релевантни политики во областа на зачувување имаат изречни заштитни политики (види, на пример, УНФЦЦЦ Договор од Канкун Додаток 1). Доброволните јаглеродни проекти често ги следат Стандардите за клима, заедница и биодиверзитет. Утврдени се и други заштитни мерки за инвестициите од Светската банка. Овие системи за заштитни мерки се воспоставени за да се очекуваат и да се избегнуваат негативните последици од интервенциите и може да се користат како основа за заштитна мерка за РЗП соодветна на локалниот контекст. 


\section{Критериум 7: Со РЗП се управува на приспособлив начин, врз основа на докази}

Овој критериум е цврсто поврзан со показателите 2.3 и 3.3.

РЗП ги користат услугите на екосистемите, кои се сложени, динамични и самоорганизирани системи. Екосистемите може да одговорат на интервенциите на РЗП напосакуваниот начин. Но интервенциите може да предизвикаат и несакани, непредвидени и ненамерни последици. Токму затоа, Р3П претставуваат обиди да се влијае врз екосистемите со цел нивна промена на начин на којшто тие ќе ги исполнат општествените потреби на долг рок и не може да се сметаат за интервенции што можат целосно да го предвидат исходот во апсолутна смисла на решавање проблеми. Како резултат, РЗП треба да се засноваат врз теоријата на промената, која е тестирана и приспособена врз основа на докази. Теоријата на промената треба да ги препознае својствата за самоорганизирање на екосистемите и треба да се заснова врз проценката на процесите и функциите, поради тоа што тие се однесуваат и се поврзани со општествените предизвици. Во теоријата на промената мора јасно да се наведат клучните претпоставки во однос на ризикот од систематски неуспех и да се тестираат во однос на доказите или преку експериментирање. Исто така, во теоријата на промената треба да се идентификуваат и позитивните услови за РзП.

Според тоа, приспособливото управување треба да се вметне во процесот на спроведување на РЗП. Приспособливото управување се дефинира како „структуриран, повторлив процес на... носење одлуки во пресрет на несигурноста, со цел постепено намалување на таквата несигурност". Исто така, во одговор на таквиот управувачки пристап, континуираното учење за процесите што се случуваат во рамките на системот и приспособувањето на РзП во согласност со системските промени е нешто што е потребно од страна на сите вклучени засегнати страни. Тука исто така може да се вклучат и согледувањата на долгорочните влијанија врз одржливоста на непосредната средина на РЗП, промените што може да бидат поттикнати во околните и низводните копнени/ приморски предели и влијанијата што би можеле да настанат во поголем размер и, со текот на времето, и во географскиот простор.

Од друга страна, несаканите влијанија врз околните, низводните копнени/приморски предели и системите од поголем обем може да се надвор од контролата на засегнатите страни. Сето ова ја истакнува потребата за приспособливо управување, флексибилност и повторливо учење при спроведувањето на РЗП. Поддржувањето на таквите пристапи кон учењето и управувањето би било признавање на интеракциите помеѓу општествените и еколошките компоненти на целокупниот систем во рамките на даден копнен предел/приморски предел, како и интеракциите што се случуваат во рамките на различни нивоа на општествено и еколошко ниво. Овој успех во голема мера зависи од Критериумот 5 и од инклузивното, транспарентно и зајакнувачко владееее. Приспособливото управување исто така може да придонесе за мерење на количината на јаглерод во почвата, вегетацијата и неговата перманентност со текот на времето, како и промените во составот на биодиверзитетот.

\section{К-7.1 Стратегијата за РЗП е утврдена и се користи како основа за редовно следење и евалуација на интервенцијата}

Во едно РЗП, теоријата на промената не е статична; таа е динамична и ја зема предвид несигурноста на биоекономските системи и променливите услови. Претпоставките и овозможувачките фактори идентификувани во теоријата на промената мора редовно да се разгледуваат во однос на воспоставените основни параметри. Останатите релевантни и нови општествени, економски и еколошки докази коишто би можеле да го подобрат влијанието на РЗП, како и да ги намалат ризиците од негативните непосакувани исходи, треба исто така да се разгледаат заедно со основните параметри. 
Составувањето план за мониторинг и евалуација исто така ќе овозможи систематско ревидирање на интервенцијата на РЗП наспроти основните параметри и останатите нови докази.

\section{К-7.2 Планот за следење и евалуација е изготвен и се спроведува во текот на животниот циклус на интервенцијата}

Планот за мониторинг и евалуација (МиЕ), по можност партиципативен план за МиЕ, којшто во верификацијата на резултатите и учењето ги вклучува засегнатите страни, ќе овозможи интервенцијата на РЗП да е на пат за имплементација и реализација и ќе помогне во управувањето со позитивните и негативните долгорочни влијанија. Иако понекогаш може да се перципира како административно оптоварување, тоа е моќен пристап кон разбирање на тоа дали дадената интервенција на РЗП ефективно ги решава општествените предизвици. Со цел да се обезбеди согледувањата за мониторингот да не се компромитираат поради мерките за намалување на трошоците, сите планови за мониторинг треба да се изготват пред имплементацијата. Онаму каде што е потребно, можно е МиЕ да треба да бидат независни и спроведени од трета страна. Во случај на самоверификација или верификација од втора страна, особено се препорачува да се спроведе надворешна ревизија или евалуација на иницијативата, во идеални услови на средината и на крајот.

Кога се правилно спроведени, МиЕ може да помогнат во проценката на промените во текот на интервенцијата, но исто така и да се детектираат непосредните и краткорочните влијанија врз природата и животите на луѓето. На тој начин ќе се поддржат интервенциите на РЗП, притоа одржувајќи соодветно ниво на отчетност и усогласеност со барањата.

Таквиот план за МиЕ е исто така важен при утврдувањето на активностите во рамките на променливи услови опишани во Показателот 7.1 и при управување со резултантните отстапувања. Ваквите активности ќе служат како дејства на приспособливо управување што треба да се преземат од страна на заедницата на заинтересирани страни. Дејствата мора да бидат развиени и спроведени на инклузивен и партиципативен начин, почитувајки ги барањата на Критериумот 5. Информациите за процесите за идентификување на активностите, како и нивното спроведување, мора да бидат достапни за инспекција, со соодветни атрибути, притоа почитувајќк ги приватноста и безбедноста на информаторите. Во рамки на МиЕ треба да бидат отсликани и соодветните еколошки и општествени обеми, поради тоа што РЗП може да има свое влијание во рамки на повеќе различни обеми и активностите може да налагаат ангажирање во рамки на обеми различни од оригиналното РЗП. Без таков приспособлив пристап, активностите може да останат на ниво на маргинални влијанија или воопшто да немаат никакво влијание.

\section{К-7.3 Рамката за итеративно учење која овозможува приспособливо управување се применува во текот на целиот животен циклус на интервенцијата}

Учењето е процес на развивање на разбирање засновано врз докази, а адаптацијата претставува приспособување на управувањето во согласност со новите информации. Учењето засновано врз докази треба да е главен двигател на управувањето со РЗП. Исто така, повторливиот процес учење-применаучење е од суштинска важност во обликувањето на дејствата на приспособливо управување со цел да се одговори на факторите што влијаат врз интервенциите на РЗП. За овој Критериум, показателите 7.1 и 7.2 даваат континуирано повратно мислење со цел учење и приспособување на интервенциите на РЗП. Таквиот процес на давање повратна информација може да се вметне како дел од планот за мониторинг и евалуација на интервенцијата, овозможувајќ́ конзистентна временска рамка за повторна анализа. Дополнителните докази, добиени од традиционални извори и од научното знаење, може исто така да се внесат во процесот на повторливо учење. Ова е особено важно имајќ́ го предвид влијанието на климатските промени со коешто се соочуваат екосистемите. Во идеални услови, повторливото учење е институционализирано, со цел да продолжи дури и по завршувањето на интервенцијата на РЗП. 


\section{Критериум 8: РЗП се одржливи и интегрирани во рамките на контекст на соодветна надлежност}

Со оглед на тоа што РЗП е релативно нов концепт во подем, информациите за РЗП мора слободно и отворено да циркулираат, со цел да се зголеми потребата и побарувачката за РЗП. На тој начин на луѓето им се овозможува да ги екстрахираат научените лекции за да утврдат дали и како треба да се приспособат процесите за РЗП. Откако добро ќе се разбере, треба да постои можност за сразмерно зголемување и/или реплицирање на поединечното РЗП. И сразмерното зголемување и реплицирањето ќе додадат докази за пристапот на РЗП и негово разбирање, со што дополнително ќе се олесни дизајнирањето на уште поделотворно, пристапно и одржливо РЗП.

РЗП се дизајнирани и управувани со цел да бидат комплементарни кон институционалните структури, политики, планови, закони, прописи и слични интервенции (видете го делот Дизајн приспособлив на обем - Критериум 2 и Критериум 7 - Приспособливо управување). Меѓутоа, додека дадената интервенција на РЗП може да биде временски ограничена (на пример, онаму каде што конкретните активности, како што е садење на мангрови дрвја, се ограничени на времетраење од пет години), РЗП генерално, вклучувајќи ги и резултантната рамка и влијание, продолжува да функционира и надвор од ваквите граници. Целта на овој критериум е РЗП да го овозможат своето сопствено интегрирање со цел решенијата да може да опстојат со текот на времето.

При поддржувањето на прифаќањето и сразмерното димензионирање на РЗП во рамките на времето и надвор од временските граници на дадената интервенција, практичарите што работат во областа наРЗПтребадасепогрижатРЗПдаимаат долгорочна траекторија што опфаќа неколку децении. Постојат разновидни пристапи кон интегрирање на РЗП, но сите се потпираат врз стратегиски комуникации и информирањето. Публиката што треба да се земе предвид се состои од поединци (јавност, научници), институции (национални влади, стартап компании, невладини организации) и глобални мрежи (Цели за одржлив развој, Договорот од Париз).

\section{К-8.1 Дизајнот на РЗП, спроведувањето и научените лекции се споделуваат за да се поттикне трансформативна промена}

За еден пристап на РЗП да биде сразмерно зголемен (интегриран), сразмерно проширен (проширен во географски, секторски или целни пропорции) или реплициран, важно е процесите на дизјнирање и спроведување, заедно со научените лекции, да им бидат достапни и пристапни на релевантните поединци или, пак, на барање на која било засегната страна што е директно опфатена или која има особен интерес за реплицирање на процесот. Публиката за оваа комуникација вклучува поединци, како што се носителите на одлуки во секторите каде што РЗП може да бидат решенија, инвеститори, корисници на РЗП од јавниот и од приватниот сектор и пошироката јавност. Примерите вклучуваат брошури за научените лекции, известувања за печат за склучените партнерства, обука за капацитети за дизајнирање или спроведување, известувања за политики и лобирање. Во лекциите мора да бидат вклучени и позитивните и негативните (вклучувајќи ги и неочекуваните) последици и можните начини за нивно надминување во иднина.

За ваквата комуникација да биде широко достапна, мора да се земат предвид оние категории кои би можеле да се соочат со бариери во однос на технологијата, културата или социоекономското потекло. Практичарите што работат во областа на РЗП треба да размислат дали би било соодветно резултатите да ги објават на издавачки софтвер со отворен пристап. Исто така, треба да се земе предвид и видливоста и зголемувањето на свесноста на самата локација, како, на пример, со помош на билборди и знаци. 


\section{К-8.2 Со РЗП се обезбедуваат информации и се јакне олеснувањето на политичките и на регулаторните рамки за поддршка на нивната употреба и интегрирање}

Р3П се веќе предмет на голем број претходно донесени политики, планови, закони и регулативи, кои во одредени случаи се ограничувачки, а во други поддржувачки. Со помош на РЗП, потребно е да се решат и да се постигне компатибилност со контекстот даден во рамки на тековните политики, планови, закони и прописи, со цел да можат целосно да ги исполнат посакуваните резултати (Дизајн приспособлив на обем, Критериум 2) или да се предложат нови политики и прописи за да се гарантира нивното успешно спроведување. Во спротивно, може да се загрози трајноста и изводливоста на РЗП на долг рок доколку, на пример, се потребни дејства или интервенции што се во спротивност или, пак, на друг начин се некомпатибилни со воспоставените стратешки политики и практики за користење на земјиштето. Исто така, може да се јават ситуации во кои постојните политики за употреба на земјиштето се меѓусебно конфликтни и според тоа, претставуваат дополнителни предизвици за спроведувањето на РЗП. Во вакви околности, РЗП може да дадат можност за истакнување на ваквите спротивставености пред креаторите на политиките и да делуваат како поттикнувач за промена и дополнување на прописите со цел да се обезбеди одржливост и трајност.

Во дадени пригоди може да се сретнат контрадикторности помеѓу целите или барањата на различните политики за користење на земјиштето или секторски политики, што потенцијално ја намалуваат ефективноста и/или ефикасноста на спроведувањето на РЗП. Тие треба целосно да се документираат заедно со можностите за решавање или заобиколување на ваквите пречки за цели на мониторингот и за разгледување од страна на креаторите на политики. Со цел да се подобри дизајнот и да се олесни делотворното усогласување на политиките за идните Р3П, резултатите од мониторингот и проценката, како и другите облици на научени лекции треба да се чуваат и да бидат лесно достапни во рамки на јавниот домен.
К-8.3 Онаму каде што е релевантно, РЗП придонесува кон националните и глобалните цели за човечката благосостојба, климатските промени, биодиверзитетот и човековите права, вклучувајќи ја и Декларацијата на Обединетите нации за правата на домородните народи (УНДРИП)

Целта на РЗП е решавање на глобалните општествени предизвици. Поединечните РЗП се надградуваат врз ваквата определба, бележејки го нивниот напредок кон сѐ поголема човекова благосостојба (вклучувајќи ги здравјето, изобилието итн.) и справување со кризата со климата и биодиверзитетот. Онаму каде што влијанијата на РЗП придонесуваат за релевантните национални и глобални цели (мапирани во Дизајн приспособлив на обем - Критериум 2), треба да се информираат телата одговорни за ваквите цели за да може да се документира ваквото влијание. Целите што треба да се земат предвид се следните:

- Националните и поднационалните политики, прописи и закони;

• Ц Целите за одржлив развој на ОН (ЦОР);

- Декадата на ОН за обнова на екосистемите;

- Целите на Конвенцијата на ОН за борба против опустинувањето (UNCCD), како што е неутрализација на деградацијата на земјиштето;

- Конкретно поврзаните со даден општествен предизвик (Договорот од Париз, Светската здравствена организација (СЗО), Глобалните цели за исхрана, Рамката за намалување на ризиците од катастрофи од Сендаи - (РНPK);

- Оние специфични за кризата со биодиверзитетот (Целите од Аичи и нивниот наследник, Протоколот од Нагоја за пристап и споделување на придобивките или неговиот наследник, Националните стратегии и акциски планови за биодиверзитет - НСАПБ)

Информирањето на одговорните во однос на целите може да се постигне преку пренос на знаења, известувања за политиките, одржување состаноци со креаторите на политиките или изготвување извештаи за различните механизми применети во политиките. 


\section{5. Како се користи Стандардот}

Стандардот е составен за да се користи при дизајнирањето, сразмерното зголемување и верификацијата како едноставна, но сепак робусна и практична алатка со која се зајакнуваат најдобрите практики, решавајќи и коригирајќи ги недостатоците и овозможувајќи интервенциите да се усогласат со меѓународноприфатенитеначелазаРЗП (WCC-2016Res-069). Корисниците можат да го применуваат Стандардот за тековни и предложени интервенции, користејќи ја алатката за самооценување која е замислена да се користи заедно со постојните алатки за проектно управување и со техничките пристапи. Показателите, нивните упатства и скалите за оценување може лесно да се усогласат со постојните известувачки и оперативни системи за управување, со цел дополнителната потребна работа да се сведе на минимум.

Во првичната фаза на примена на Стандардот заРЗП, развиена е алатка за самооценување (што може да се преземе овде), со цел корисниците на Стандардот да можат да го пресметаат процентуалниот удел на нивната интервенција во споредба со осумте критериуми и да утврдат дали нивната интервенција е во согласност со Глобалниот стандард на IUCN за РЗП. Документот за самооценување, во форма на табела во Ексел, на корисниците им овозможува да го утврдат степенот до којшто нивната интервенција е во согласност со поединечните Показатели: „многу“, „соодветно“, „делумно“ или „недоволно“. Корисниците исто така имаат на располагање т.н. систем на светлосна сигнализација за секој критериум, што им овозможува да ги утврдат областите во кои е потребно подобрување и целокупно совпагање со цел да дефинираат дали дадената интервенција е во согласност со Глобалниот стандард на IUCN за Р3П.

За секој показател се евидентира еден резултат од четири, во зависност од тоа дали показателот за интервенцијата е на ниво на "многу", "соодветно“, "Делумно“ или „недоволно“. Резултатот се користи за пресметка на нивото на усогласеност со секој поединечен критериум, при што исто така се добива резултат „многу“, „соодветно“, „делумно“ и „недоволно“ за резултати повисоки од 75, помеѓу 50 и 75, помеѓу 25 и 50 и пониски од 25 проценти (Табела 1). Ваквите резултати за показателите потоа се нормализираат, со цел секој критериум за да има еднаква тежина. По нормализацијата, резултативе за критериумите се комбинираат со цел да се добие целокупно процентуално совпаѓање. Без оглед на целокупното процентуално совпаѓае, доколку резултатот за дадена интервенција е оценет со „недоволно“ при споредбата со кој било критериум, тогаш не е во согласност со Глобалниот стандард на IUCN за РЗП. Процентуалното совпаѓање потоа може да се користи за да се опише дали даденото придржување е со ранг „многу“, „соодветно“ или "делумно".

табела 1: Резултати од листот за самооценување.

\begin{tabular}{|c|c|c|}
\hline \multicolumn{2}{|c|}{ Легенда (\%) } & \multirow[t]{2}{*}{ Резултат } \\
\hline$\geq 75$ & Многу & \\
\hline$\geq 50 \&<75$ & Соодветно & \multirow[t]{2}{*}{$\begin{array}{l}\text { Интервенцијата е во согласност со Глобалниот стандард на } \\
\text { IUCN за РЗП. }\end{array}$} \\
\hline$\geq 25 \&<50$ & Делумно & \\
\hline$<25$ & Недоволно & Интервенцијата не е во согласност со Глобалниот стандард на IUCN за Р3П. \\
\hline
\end{tabular}


Додека со Стандардот се проценува дали дизајнот за дадена интервенција е во согласност со квалификациските барањата на РЗП, неговото насоките за интегрирано управување со водните ресурси заради операционализација на РЗП, само доколку е тоа дизајнирано во согласност со осумте

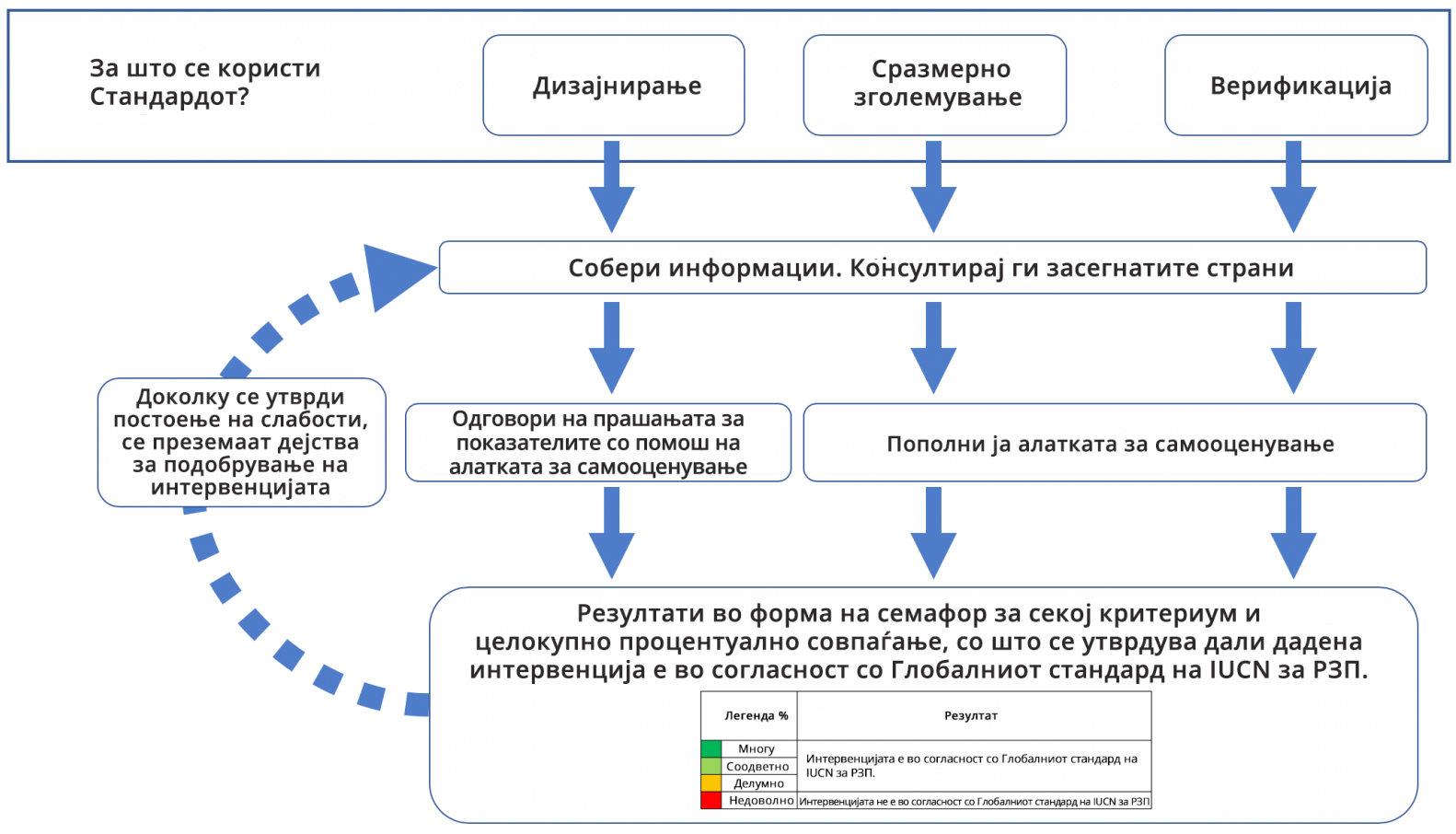

слика 7: Како да се користи Стандардот и на кој начин е поврзан со самооценувањето (ㅇ IUCN)

спроведување наложува други оперативни стандарди, алатки и пристапи. На пример, доколку постои потреба да се управува со дадена вододелница со цел намалување на ризиците од поплава, би биле потребни алатки како што се критериуми (Слика 7). Во таа смисла, Глобалниот стандард на IUCN за РЗП повеќе служи како дополнување, а не како замена за другите стандарди.

\section{1 Како се врши самооценување}

Самооценувањето во однос на Стандардот за РзП треба да се изведува во различни фази на проектниот циклус, со цел да се помогне во идентификацијата на неочекуваните исходи, слабости и силни страни за тие да се подобрат или да се ублажат. Според тоа, кон самооценувањето не треба да се гледа како кон донесување суд за дадениот проект за РЗП. Поточно, целта е да се обезбеди постигнување на предвидените општествени предизвици, без притоа да се компромитира природата и обратно. При самооценувањето се користи систем на семафор за да се наведе статусот на различните наведени Показатели, каде што зеленото светло укажува на тоа дека дадениот Показател е целосно исполнет, портокаловото дека има делумно исполнување, а црвеното дека Показателот воопшто не е исполнет. 
Самооценувањето треба да се спроведе на следниот начин:

- Разгледајте ги показателите, упатствата и примерите дадени во Дел II и размислете околу предложените мерки за верификација;

- Идентификувајтеги средстватаза верификација што се најсоодветни за да се докаже до кој степен вашето РЗП го исполнува соодветниот показател, користејќи ја скалата со степени „многу", „соодветно“, „делумно“ и „недоволно“ дадена во алатката за самооценување;

- Опишете на кој начин и до колкав степен вашето РЗП ги исполнува барањата на показателот во полињата дадени во алатката за самооценување;

- Приложете линкови до средствата за верификација што сте ги користеле (доколку се достапни на интернет) или прикачете ги на вашето самооценување со цел да ги поддржите вашите наоди;
- Проверете го листот со резултатите во облик на семафор, целокупното процентуално совпаѓање и тоа дали интервенцијата е во согласност со Глобалниот стандард на IUCN за РЗП;

- Споделете, составете извештај и дискутирајте околу наодите потребни за подобрување или за спроведување на решенијата;

· Бидете флексибилни и повторете го процесот во согласност со потребното во случај на промена на некои аспекти.

Деловите | и || од Стандардот подоцна ќе бидат дополнети со корисничко упатство (Дел III) и пристапи и алатки за споделување на платформи. Во меѓувреме, корисниците на Стандардот може да се придружат на глобалната заедница на практичари, каде што може да добијат помош и одговор на најчесто поставуваните прашања. Вашите прашања исто така може да се испратат до Групата за Р3П во IUCN на NbSStandard@iucn.org. 


\section{Поимник на дефиниции}

Термин

Активност

Дефиниција

Активностите не се сметаат за реактивно однесување или промена на начинот на живеење, туку за активна примена на демократското учество во општеството. Активноста треба да се преземе на свесен, намерен и доброволен начин

\section{Извор}

Врска (линк)

Поимник од пакетот https://www.cbd.int/cepal алатки за КБР toolkit/2008/doc/CBD-ToolkitGlossaries.pdf

\begin{tabular}{|c|c|c|c|}
\hline Акциски план & $\begin{array}{l}\text { Пишан план за спроведување во којшто често се } \\
\text { детално наведени временскиот распоред, фазите, } \\
\text { улогите и/или одговорностите на проектите во врска } \\
\text { со целите од стратегијата. }\end{array}$ & CBD Toolkit Glossary & $\begin{array}{l}\frac{\text { https://www.cbd.int/cepa/ }}{\text { toolkit/2008/doc/CBD-Toolkit- }} \\
\text { Glossaries.pdf }\end{array}$ \\
\hline $\begin{array}{l}\text { Прилагоду- } \\
\text { вање }\end{array}$ & $\begin{array}{l}\text { Иницијативи и мерки за намалување на ранливоста } \\
\text { на природните и човечките системи во однос } \\
\text { на реалните или очекуваните влијанија од } \\
\text { климатските промени. Постојат различни видови } \\
\text { на приспособување, на пример, со предвидувања } \\
\text { и реактивни, приватни и јавни и самостојни и } \\
\text { планирани. }\end{array}$ & Поимник на IUCN & $\frac{\text { https://www.iucn.org/sites/ }}{\text { dev/files/iucn-glossary-of- }}$ \\
\hline $\begin{array}{l}\text { Приспо- } \\
\text { собливо } \\
\text { управување }\end{array}$ & $\begin{array}{l}\text { Систематски процес на континуирано подобрување } \\
\text { на политиките за управување и на практиките преку } \\
\text { учење од резултатите од постојните програми }\end{array}$ & Поимник на IUCN & $\begin{array}{l}\frac{\text { https://www.iucn.org/sites/ }}{\text { dev/files/iucn-glossary-of- }} \\
\underline{\text { definitions en.pdf }}\end{array}$ \\
\hline Оценка & $\begin{array}{l}\text { Анализа и ревидирање на информациите што } \\
\text { произлегуваат од истражувањето со цел да се } \\
\text { помогне на некој на позиција на одговорност да ги } \\
\text { евалуира можните активности или да размислува за } \\
\text { проблем. Оценката значи собирање, резимирање, } \\
\text { организирање, толкување и можно усогласување } \\
\text { на деловите од постојното знаење и нивно } \\
\text { соопштување за да бидат релевантни и корисни за } \\
\text { интелигентниот, но неекспертски носител на одлуки. }\end{array}$ & $\begin{array}{l}\text { Поимник за } \\
\text { мапирање на } \\
\text { екосистемски услуги } \\
\text { и терминологија за } \\
\text { оценка }\end{array}$ & $\frac{\text { https://oneecosystem.pensoft. }}{\underline{\text { net/articles.php?id=27110 }}}$ \\
\hline $\begin{array}{l}\text { Основни } \\
\text { параметри }\end{array}$ & $\begin{array}{l}\text { Референци за мерливи количества од коишто } \\
\text { може да се измери алтернативен резултат, на } \\
\text { пример, сценарио без интервенции што се користи } \\
\text { како референца во анализата на сценаријата со } \\
\text { интервенции. }\end{array}$ & ИПЦЦ & $\begin{array}{l}\frac{\text { https://www.ipcc.ch/pdf/ }}{\text { assessment-report/ar4/syr/ }} \\
\underline{\text { ar4 syr appendix.pdf }}\end{array}$ \\
\hline $\begin{array}{l}\text { Корисници } \\
\text { на екосистем- } \\
\text { ските услуги }\end{array}$ & $\begin{array}{l}\text { Кое било лице, група лица или субјект што користи } \\
\text { или веројатно ке ги користи придобивките од } \\
\text { природата што ги обезбедува раководната единица. } \\
\text { Примерите вклучуваат, но не се ограничени на } \\
\text { лица, група лица или субјекти кои се лоцирани } \\
\text { во соседството на единицата за управување. } \\
\text { Крајните корисници, како што се потрошувачите } \\
\text { или индиректните корисници на намалувањето на } \\
\text { јаглеродот, не се сметаат за корисници. }\end{array}$ & $\begin{array}{l}\text { Постапка за } \\
\text { екосистемски } \\
\text { услуги: Алатки за } \\
\text { пазар и приказ на } \\
\text { влијанија }\end{array}$ & $\frac{\underline{\text { https://ic.fsc.org/file- }}}{\text { download.ecosystem-services- }}$ \\
\hline $\begin{array}{l}\text { Придобивки/ } \\
\text { влијание }\end{array}$ & $\begin{array}{l}\text { Придобивки: Позитивна промена на } \\
\text { „благосостојбата“ поради исполнување на потребите. } \\
\text { Во однос на влијанието: Позитивно влијание врз } \\
\text { поединците, општеството и еколошките ресурси, што } \\
\text { е резултат од промената во животната средина }\end{array}$ & $\begin{array}{l}\text { Поимник за } \\
\text { мапирање на } \\
\text { екосистемски услуги } \\
\text { и терминологија за } \\
\text { оценка }\end{array}$ & $\begin{array}{l}\text { https://oneecosystem.pensoft. } \\
\text { net/articles.php?id=27110 }\end{array}$ \\
\hline $\begin{array}{l}\text { Биодиверзи- } \\
\text { тет }\end{array}$ & $\begin{array}{l}\text { Биодиверзитет - скратено од биолошка } \\
\text { разновидност - значи разновидност на животот } \\
\text { во сите негови форми - разновидност на видови, } \\
\text { генетички варијации кај еден вид и разновидност } \\
\text { на екосистемите. Важноста на биолошката } \\
\text { разновидност за човечкото општество е тешко } \\
\text { да се оцени. Околу } 40 \text { \% од глобалната економија } \\
\text { се заснова врз биолошки производи и процеси. } \\
\text { сиромашните луѓе, а особено оние кои живеат } \\
\text { во области со ниска земјоделска продуктивност, } \\
\text { значително зависат од генетичката разновидност на } \\
\text { животната средина. }\end{array}$ & $\begin{array}{l}\text { Поимник од пакетот } \\
\text { алатки за КБР }\end{array}$ & $\frac{\text { https://www.cbd.int/cepa/ }}{\text { toolkit/2008/doc/CBD-Toolkit- }}$ \\
\hline
\end{tabular}


Термин Дефиниција

Уште од времето кога луѓето првпат се појавиле на Земјата и почнале да ловат животни, да собираат храна и да сечат дрвја, тие имале влијание врз биодиверзитетот. Во текот на последните два века, растот на популацијата на човекот, преголемото искористување на природните ресурси и

Загуба на биодиверзитетот деградацијата на животната средина резултираа во забрзано намалување на глобалниот биодиверзитет. Видовите се намалуваат по број и исчезнуваат, а екосистемите се оштетуваат и исчезнуваат. Околу 80 \% од првичните шуми кои ја покривале Земјата пред 8000 години се веќе исечени, оштетени или фрагментирани. Според некои експерти, стапката по која видовите изумираат е од 1000 до 10000 пати повисока од природната стапка.
Поимник од пакетот алатки за КБР

https://www.cbd.int/cepa/ toolkit/2008/doc/CBD-ToolkitGlossaries.pdf
Слив

Област во која тече река или тело на вода. Терминот често се користи наизменично со „вододелница“. Види ја дефиницијата за „вододелница“.

\section{Услуги за \\ климатско \\ приспосо- \\ бување}

Придобивки за луѓето од зголемената општествена приспособливост на промената, обезбедени од капацитетот на екосистемите да се приспособат кон климатските промени и варијабилност.
Поимник на IUCN

https://www.iucn.org/sites/ dev/files/iucn-glossary-ofdefinitions en.pdf

Публикација на

IUCN од 2016

за Решенија

засновани врз

природата (Лаворел

https://portals.iucn.org/ library/sites/library/files/ и др., 2015)
Климатски промени. Климатските промени се однесуваат на која било промена која настанува со текот на времето, без оглед дали е поради природната варијабилност или е резултат од активноста на човекот. Оваа употреба се разликува од онаа во Рамковната конвенција на Обединетите

Климатски промени нации за климатски промени, каде што „климатските промени“ се дефинираат како: „Промена на климата што директно или индиректно се припишува на активноста на човекот со која се менува составот на глобалната атмосфера и која е дополнување на варијабилноста на природната клима што се забележува во споредлив временски период".

\section{Поимник на IUCN $\frac{\text { https://www.Iucn.org/sites/ }}{\text { dev/files/iucn-glossary-of- }}$ definitions en.pdf}

Завршувањето на проектот има за цел да обезбеди лекции од проектот што ќе се користат во иднина.
IUCN PAAS

\section{Меѓународни}

стандарди за

праксата на

еколошка обнова

- вклучувајќи

ги и начелата и

клучните концепти https://www.iucn.org/

resources/project-

management-tools/projectguidelines ично се наведува ви или родот (за растенија и фауна на рбетници) или барем редот (за безрбетници и микроорганизми).

\section{Поимник на}

Единица на знаење која се креира со единствена комбинација од карактеристики. Концептите се апстрактни резимеа, општи концепти, знаење, итн. на цел збир однесувања, ставови или

Концепт карактеристики за коишто се смета дека имаат нешто заедничко. Концептите се користат за да помогнат во презентирањето/пренесувањето на точното значење, категоризација, толкување, структурирање и разбирање на појавата.

тите нации

за класификација

на термини,

изготвен од

Експертската група

за меѓународна

економска

и социјална

класификација
http://data.un.org/Glossary. aspx?q=scientific +knowledge http://seraustralasia. $\mathrm{com} /$ wheel/image/SER International Standards.pdf 
термин Дефиниција

Извор

Врска (линк)

Некомпатибилност меѓу опции, начела, итн. Конфликтот не е секогаш несоодветен, абнормален или дисфункционален, туку е наследен елемент од човековите интеракции. Кога се размислува за насоките кои општеството ги презема, она што е

Конфликт насоките кои општеството ги презема, она што е
најважно се процесите за управување со кои се справуваме со конфликтот. Кога има конфликт, страните може помалку да сакаат или да можат целосно или конструктивно да учествуваат во преговорите сѐ до соодветно признавање на конфликтот.

\begin{tabular}{ll}
\hline & Надворешни размени - двонасочни протоци што \\
& настануваат меѓ еколошките единици во пределот \\
поврзаност & или водната средина, вклучително и протокот на \\
& енергија, вода, оган, генетски материјал, животни \\
& и семиња. Размената е олеснета со поврзаноста на \\
& живеалиштата.
\end{tabular}

Меѓународни стандарди за праксата на еколошка обнова - вклучувајќи ги и начелата $и$ клучните концепти за правото на glossary\#PStext https://www.iucn.org/

theme/environmental-law/ our-work/water/water-law-

Поимник на IUCN животната средина platform/learning-resources/

Заштита, грижа, управување и одржување екосистеми, живеалишта, диви видови и популации, во или надвор од нивните природни средини за да се заштитат природните услови за нивно долгорочно опстојување. Зачувување ех situ. Зачувување на компонентите од биолошката разновидност надвор

Зачувување од нивните природни живеалишта. Зачувување in situ. Зачувување на екосистемите и природните живеалишта и одржување и обновување одржливи популации на видови во нивните природни средини и, во случај на припитомени и одгледувани видови, во средините во коишто имаат развиено специфични карактеристики. https://www.iucn.org/sites/ dev/files/iucn-glossary-ofdefinitions en.pdf http://seraustralasia. com/wheel/image/SER International Standards.pdf Консултациите се двонасочен процес на дијалог меѓу проектната компанија и нејзините заинтересирани страни. Консултацијата со заинтересирани страни се однесува на започнување и одржување конструктивни надворешни односи со текот на времето. Компаниите кои рано го почнуваат процесот и имаат долгорочен, стратешки поглед, во суштина, ја развиваат нивната „општествена лиценца за работа".

Консултации Проектните трошоци ги содржат сите трошоци што настануваат во текот на проектот. Тие може

Трошок да се пресметаат за поединечни работни пакети, за поединечни предмети кои се разгледуваат, за интерни задачи и за целиот проект.

Меѓународна
финансиска
корпорација

https://www.ifc.org/wps/wcm/ connect/5a4e740048855591 b724f76a6515bb18/PartOne StakeholderConsultation. pdf?MOD=AJPERES
Gareis, R.,Huemann,

M., \&Martinuzzi, A.,

2010.Поврзување

на одржлив развој

и управување

со проект:

концептуален https://www.pmi.org/learning/ library/relating-sustainabledevelopment-projectmanagement-6497

\begin{tabular}{|c|c|c|c|}
\hline $\begin{array}{l}\text { Анализа на } \\
\text { трошоци и } \\
\text { придобивки }\end{array}$ & $\begin{array}{l}\text { Алатка за одлучување со која се оценува } \\
\text { посакуваноста на проектите преку споредба на } \\
\text { нивните трошоци и придобивки. }\end{array}$ & Поимник на IUCN & $\begin{array}{l}\text { https://www.iucn.org/sites/ } \\
\text { dev/files/iucn-glossary-of- } \\
\underline{\text { definitions en.pdf }}\end{array}$ \\
\hline Културно & $\begin{array}{l}\text { „Културно“ се однесува на духовните, материјалните, } \\
\text { интелектуралните и емоционалните карактеристики } \\
\text { на општеството или на општествената група } \\
\text { покрај уметноста и литературата, начинот на } \\
\text { живеење, системите за вреднување, традицијата и } \\
\text { убедувањата. }\end{array}$ & УHECKO & $\begin{array}{l}\text { https://unesdoc.unesco.org/ } \\
\underline{\text { ark:/48223/pf0000127162 }}\end{array}$ \\
\hline $\begin{array}{l}\text { Културна } \\
\text { разновидност }\end{array}$ & $\begin{array}{l}\text { Разновидност или мултиформност на човечките } \\
\text { општествени структури, системи за убедување } \\
\text { и стратегии за приспособување кон ситуации } \\
\text { во различни делови од светот. Јазикот е добар } \\
\text { показател за културната разновидност, а во } \\
\text { моментов се зборуваат повеќе од } 6000 \text { јазици. }\end{array}$ & $\begin{array}{l}\text { Поимник од пакетот } \\
\text { алатки за КБР }\end{array}$ & $\begin{array}{l}\text { https://www.cbd.int/cepa/ } \\
\text { toolkit/2008/doc/CBD-Toolkit- } \\
\underline{\text { Glossaries.pdf }}\end{array}$ \\
\hline
\end{tabular}




\begin{tabular}{|c|c|c|c|}
\hline Термин & Дефиниција & Извор & Врска (линк) \\
\hline $\begin{array}{l}\text { Културни } \\
\text { екосистемски } \\
\text { услуги }\end{array}$ & $\begin{array}{l}\text { Нематеријални придобивки кои луѓето ги добиваат } \\
\text { од екосистемите преку духовно збогатување, } \\
\text { когнитивен развој, рефлексија, рекреирање и } \\
\text { естетско искуство, вклучувајќи ги, на пример, } \\
\text { системите на знаење, општествените односи и } \\
\text { естетските вредности. }\end{array}$ & $\begin{array}{l}\text { Милениумски } \\
\text { екосистемски услуги } \\
\text { - МЕА }\end{array}$ & $\begin{array}{l}\frac{\text { https://www. }}{\text { millenniumassessment.org/ }} \\
\text { documents/document.776. } \\
\underline{\text { aspx.pdf }}\end{array}$ \\
\hline $\begin{array}{l}\text { Носител на } \\
\text { одлуки }\end{array}$ & $\begin{array}{l}\text { Лице чии одлуки и активностите што произлегуваат } \\
\text { од нив може да влијаат врз состојбата, процесот или } \\
\text { предметното прашање. }\end{array}$ & $\begin{array}{l}\text { Милениумски } \\
\text { екосистемски услуги } \\
\text { - МЕA }\end{array}$ & $\begin{array}{l}\text { https://www. } \\
\text { millenniumassessment.org/ } \\
\text { documents/document.776. } \\
\text { aspx.pdf }\end{array}$ \\
\hline
\end{tabular}

Сериозно нарушување на функционирањето на заедницата или општеството што предизвикува широко распространети човечки, материјални, економски или еколошки загуби кои ја надминуваат способноста на засегнатата заедница или општество да се справат со употреба на сопствени ресурси (ISDR 2004). Намалување на ризик од катастрофи. Луѓето и институциите кои се вклучени во подготвеноста,

Катастрофа намалувањето (на пр., јакнење на градежните структури, подобрување на јавната свест за ризиците од катастрофи) и активностите за спречување (на пр., садење дрвја за да се стабилизираат речните брегови) во врска со екстремни настани. Тие вклучуваат прогнози за опасности и директна помош за големи катастрофи што се резултат од поплави, циклони и, во некои случаи, загадување (приспособување од IISD/IUCN/SEI 2003).

Потенцијална загуба на живот, повреда, уништени или оштетени ресурси кои може да настанат кај

Ризик од катастрофи еден систем, општество или заедница во определен временски период, којшто се определува како функција на непогоди, изложеност, ранливост и капацитет.
Monty, F., Murti, R., Miththapala, S. and

Buyck, C., 2017.

Инфраструктура

која заштитува

екосистеми и

заедници: научени

лекции и насоки за

спроведување. https://portals.iucn.org/

library/sites/library/files/

documents/2017-045.pdf
Управување со системи на човечко и еколошко самодизајнирање или лесно управување кое го придружува човековиот дизајн и еколошкото

Еколошки инженеринг придружува човековиот дизајн и еколошкото
самодизајнирање за да бидат заемно симбиотски Дизајнот на одржливите екосистеми со кои се интегрира општеството на човекот со неговата природна средина за обострана корист.
Публикација

Ha IUCN 2016

за решенија

засновани врз

природата

(Odum,1996) \&

(Mitsch,2012) https://portals.iucn.org/

library/sites/library/files/ documents/2016-036.pdf

Ресурс контролиран од донатор (плен, отпадоци, хранливи материи) од едно живеалиште до реципиент (растение или потрошувач) од второ

Еколошки живеалиште, со што се зголемува продуктивноста живеалиште, со што се зголемува продуктивноста
на популацијата на реципиентот и потенцијално се менува динамиката потрошувач - ресурс во системот org/doi/pdf/10.1146/annurev. на реципиентот.

Екосистем. Во согласност со Спогодбата за биолошка разновидност, екосистемот се разбира како динамичен сложен збир од растителни, животински заедници и заедници на микроорганизми и нивната

Екосистем неживотна средина кои се во интеракција како функционална единица. Екосистемите може да бидат мали и едноставни, како што е изолирана бара, или големи и сложени, како што е некоја тропска прашума или корален гребен во тропските мориња.

Поимник на IUCN https://www.iucn.org/sites/ dev/files/iucn-glossary-ofdefinitions en.pdf 
Екосистемскиот пристап е стратегија за интегрирано управување со земјиштето, водата и живите ресурси со која се промовира зачувувањето и одржливата употреба на рамноправен начин. Со екосистемскиот пристап, потребите на човекот се ставаат во центарот

Екосистемски науправувањето со биодиверзитетот. Целта е да се пристап управува со екосистемот врз основа на повеќекратните функции што ги извршува екосистемот и повеќекратните употреби што произлегуваат од овие функции. Екосистемскиот пристап нема за цел да обезбеди краткорочни економски придобивки, туку целта е да се оптимизира употребата на екосистемот без да се оштети.
Поимник од пакетот алатки за КБР https://www.cbd.int/cepa/ toolkit/2008/doc/CBD-ToolkitGlossaries.pdf

Екосистемот се карактеризира со големината, биодиверзитет, стабилност, степен на организација, внатрешна размена на материјали, енергија и информации меѓу различни групи и други приоритети. Вклучува екосистемски функции и процеси.

Функција на екосистемот

\section{Милениумски https://www. \\ екосистемски услуги millenniumassessment.org/ \\ documents/document.776. aspx.pdf}

Состојба на екосистемот: капацитетот на екосистемот за обезбедување услуги во однос на неговиот потенцијален капацитет. Состојба на екосистемски услуги: капацитетот на екосистемската услуга да обезбеди придобивки за луѓето во однос на неговиот потенцијален капацитет.

Милениумски
екосистемски услуги
- MEA $\quad \begin{aligned} & \frac{\text { https://www. }}{\text { millenniumassessment.org/ }} \\ & \underline{\text { documents/document.776. }} \\ & \underline{\text { aspx.pdf }}\end{aligned}$

Меѓународни

стандарди за

праксата на http://seraustralasia.

Управување (со екосистем) - широка категоризација што може да вклучи одржување и поправка на екосистеми (вклучувајќи обновување/реставрација).

екосистемот

еколошка обнова

- вклучувајќи

ги и начелата и

com/wheel/image/SER

International Standards.pdf

клучните концепти

\begin{tabular}{|c|c|c|c|}
\hline $\begin{array}{l}\text { Процес во } \\
\text { екосистемот }\end{array}$ & $\begin{array}{l}\text { Секоја промена или реакција кои настануваат во } \\
\text { рамките на екосистемите, физички, хемиски или } \\
\text { биолошки. Процесите во екосистемите вклучуваат } \\
\text { распаѓање, производство, циклус на хранливи } \\
\text { материи и текови на хранливи материи и енергија. }\end{array}$ & $\begin{array}{l}\text { Поимник за } \\
\text { мапирање на } \\
\text { екосистемски } \\
\text { услуги и } \\
\text { терминологија за } \\
\text { оценка }\end{array}$ & $\begin{array}{l}\text { https://oneecosystem.pensoft. } \\
\text { net/articles.php?id=27110 }\end{array}$ \\
\hline $\begin{array}{l}\text { Својства на } \\
\text { екосистемот }\end{array}$ & $\begin{array}{l}\text { Атрибути што го карактеризираат екосистемот, } \\
\text { како што е големината, стабилноста, степенот на } \\
\text { организација, како и неговите функции и процеси } \\
\text { (т.е. внатрешната размена на материјали, енергија и } \\
\text { информации меѓу различните групи) }\end{array}$ & $\begin{array}{l}\text { Поимник за } \\
\text { мапирање на } \\
\text { екосистемски услуги } \\
\text { и терминологија за } \\
\text { оценка }\end{array}$ & $\begin{array}{l}\text { https://oneecosystem.pensoft. } \\
\underline{\text { net/articles.php?id=27110 }}\end{array}$ \\
\hline $\begin{array}{l}\text { Екосистемски } \\
\text { услуги }\end{array}$ & $\begin{array}{l}\text { Придобивки за луѓето од екосистемите. Тие } \\
\text { вклучуваат услуги за обезбедување, на пример на } \\
\text { храна и вода; услуги за регулирање, како што е } \\
\text { контрола на поплави и болести; културни услуги, како } \\
\text { што се духовни, рекреативни и културни придобивки; } \\
\text { и услуги за поддршка, како што е циклусот на } \\
\text { хранливи материи со коишто се одржуваат условите } \\
\text { за живот на Земјата. Концептот „екосистемски добра } \\
\text { и услуги“ е синоним за екосистемски услуги. }\end{array}$ & $\begin{array}{l}\text { Милениумски } \\
\text { екосистемски услуги } \\
\text { - МЕА }\end{array}$ & $\begin{array}{l}\frac{\text { https://www. }}{\text { millenniumassessment.org/ }} \\
\text { documents/document.776. } \\
\text { aspx.pdf }\end{array}$ \\
\hline
\end{tabular}

Одговорното управување со екосистеми е рамка ориентирана кон активности предвидена да промовира социјално-еколошка одржливост за планетата која многу брзо се менува. Клучната цел е да се одржи капацитетот за обезбедување екосистемски услуги со коишто се поддржува благосостојбата Одговорно на човекот во услови на несигурност и промена. управување со Во одговорното управување со екосистемите се екосистеми интегрираат три широки пристапи за одржливост коишто се преклопуваат: (i) намалување на ранливоста на очекуваните промени; (ii) промовирање на отпорност за одржување на посакувани услови при соочување со претурбации и несигурност; и (iii) трансформирање од непосакувани траектории кога настануваат можности (за промена).

Одговорно

управување

со екосистеми:

стратегии за

планетата која брзо

се менува http://dx:doi.org/10.1016/j tree.2009.10.008 


\begin{tabular}{|c|c|c|c|}
\hline Термин & Дефиниција & Извор & Врска (линк) \\
\hline $\begin{array}{l}\text { Структура на } \\
\text { екосистемот }\end{array}$ & $\begin{array}{l}\text { Статична карактеристика на „екосистем“ која се мери } \\
\text { како залиха или обем на материјал или енергија, или } \\
\text { состав и дистрибуција на биофизички елементи. }\end{array}$ & $\begin{array}{l}\text { Поимник за } \\
\text { мапирање на } \\
\text { екосистемски услуги } \\
\text { и терминологија за } \\
\text { оценка }\end{array}$ & $\begin{array}{l}\text { https://oneecosystem.pensoft. } \\
\underline{\text { net/articles.php?id }=27110}\end{array}$ \\
\hline $\begin{array}{l}\text { Приспосо- } \\
\text { бување } \\
\text { засновано врз } \\
\text { екосистем }\end{array}$ & $\begin{array}{l}\text { Употребата на биодиверзитетот и екосистемските } \\
\text { услуги како дел од севкупната стратегија за } \\
\text { приспособување за да им се помогне на луѓето } \\
\text { да се приспособат кон негативните влијанија од } \\
\text { климатските промени. }\end{array}$ & $\begin{array}{l}\text { Публикација на } \\
\text { IUCN од } 2016 \\
\text { за Решенија } \\
\text { засновани врз } \\
\text { природата - (КБР, } \\
\text { 2009) }\end{array}$ & $\begin{array}{l}\frac{\text { https://portals.iucn.org/ }}{\text { library/sites/library/files/ }} \\
\underline{\text { documents/2016-036.pdf }}\end{array}$ \\
\hline $\begin{array}{l}\text { Намалување } \\
\text { на ризик од } \\
\text { катастрофи } \\
\text { засновано врз } \\
\text { екосистем }\end{array}$ & $\begin{array}{l}\text { Одржливо управување, заштита и обновување на } \\
\text { екосистемите за да се обезбедат услуги со кои се } \\
\text { намалува ризикот од катастрофи преку ублажување } \\
\text { на опасностите и преку зголемување на отпорноста } \\
\text { на живеалиштата. }\end{array}$ & $\begin{array}{l}\text { Публикација на } \\
\text { IUCN од } 2016 \\
\text { за Решенија } \\
\text { засновани врз } \\
\text { природата - } \\
\text { (ПЕДРР, 2010) }\end{array}$ & $\begin{array}{l}\frac{\text { https://portals.iucn.org/ }}{\text { library/sites/library/files/ }} \\
\text { documents/2016-036.pdf }\end{array}$ \\
\hline $\begin{array}{l}\text { Управување } \\
\text { засновано врз } \\
\text { екосистем }\end{array}$ & $\begin{array}{l}\text { Интегриран, научно заснован пристап кон } \\
\text { управувањето со природните ресурси чија цел е да } \\
\text { се одржи здравјето, отпорноста и разновидноста } \\
\text { на екосистемите, при што се овозможува одржливо } \\
\text { користење од страна на луѓето на добрата и услугите } \\
\text { кои ги обезбедуваат. }\end{array}$ & $\begin{array}{l}\text { Публикација на } \\
\text { IUCN од } 2016 \\
\text { за Решенија } \\
\text { засновани врз } \\
\text { природата - (Kappel } \\
\text { et al., 2006) \& (Garcia } \\
\text { et al., 2003) }\end{array}$ & $\frac{\frac{\text { https://portals.iucn.org/ }}{\text { library/sites/library/files/ }}}{\underline{\text { documents/2016-036.pdf }}}$ \\
\hline
\end{tabular}

\begin{tabular}{|c|c|c|c|}
\hline $\begin{array}{l}\text { Ублажување } \\
\text { засновано врз } \\
\text { екосистем }\end{array}$ & $\begin{array}{l}\text { Јакнење на придобивките и избегнување } \\
\text { негативни влијанија врз биодиверзитетот од } \\
\text { намалените емисии, земајки ја предвид потребата } \\
\text { од осигурување на целосно и ефективно учество } \\
\text { на домородните и локалните заедници во } \\
\text { релевантното креирање политики и процеси } \\
\text { на спроведување, онаму каде што е соодветно. } \\
\text { Јакнење на зачувувањето, одржливото користење } \\
\text { и обновувањето на поморските и на крајбрежните } \\
\text { живеалишта кои се ранливи на влијанијата од } \\
\text { климатските промени или кои придонесуваат кон } \\
\text { ублажувањето на климатските промени. }\end{array}$ & $\begin{array}{l}\text { Публикација на } \\
\text { IUCN од } 2016 \\
\text { за Решенија } \\
\text { засновани врз } \\
\text { природата - (КБР, } \\
\text { 2010) }\end{array}$ & $\begin{array}{l}\frac{\text { https://portals.iucn.org/ }}{\text { library/sites/library/files/ }} \\
\underline{\text { documents/2016-036.pdf }}\end{array}$ \\
\hline Соработка & $\begin{array}{l}\text { Привлекување или вклучување нечиј интерес или } \\
\text { внимание. Соработка во/со: учество или вклученост. }\end{array}$ & $\begin{array}{l}\text { Поимник на IUCN } \\
\text { за правото на } \\
\text { животната средина }\end{array}$ & $\begin{array}{l}\text { https://www.iucn.org/ } \\
\text { theme/environmental-law/ } \\
\text { our-work/water/water-law- } \\
\text { and-governance-support- } \\
\text { platform/learning-resources/ } \\
\text { glossary\#PStext }\end{array}$ \\
\hline
\end{tabular}

\begin{tabular}{|c|c|c|c|}
\hline $\begin{array}{l}\text { Животна } \\
\text { средина }\end{array}$ & $\begin{array}{l}\text { Се однесува на сите живи и неживи компоненти и сите } \\
\text { фактори, како климата, кои се околу еден организам. } \\
\text { Често се меша со зборот „екологија“, што е всушност } \\
\text { наука која ги проучува односите на живите суштества } \\
\text { меѓу себе и со сите неживи делови од средината. } \\
\text { Животната средина може да се смета како ред од } \\
\text { плочки за домино. Од овој аспект, екологијата би била } \\
\text { проучување на меѓусебното влијание на сите плочки за } \\
\text { домино при нивно пагање. }\end{array}$ & Поимник на IUCN & $\frac{\text { https://www.iucn.org/sites/ }}{\text { dev/files/iucn-glossary-of- }}$ \\
\hline $\begin{array}{l}\text { Еднакви } \\
\text { придобивки }\end{array}$ & $\begin{array}{l}\text { Се однесува на крајното влијание на напорите за } \\
\text { развој на двата пола. Имплицира дека резултатите } \\
\text { треба да бидат еднакво проценети и искористени } \\
\text { од страна на мажите и жените. Еднаквоста на } \\
\text { можностите нужно не имплицира дека двата пола ги } \\
\text { уживаат истите придобивки. }\end{array}$ & Поимник на IUCN & $\frac{\frac{\text { https://www.iucn.org/sites/ }}{\text { dev/files/iucn-glossary-of- }}}{\underline{\text { definitions en.pdf }}}$ \\
\hline
\end{tabular}


Се бара пристап на луѓето до еднакви можности и разво на основни капацитети; тоа значи дека бариерите со коишто се попречуваат економските и политичките можности, како и пристапот до образование и основните услуги, треба да се отстранат, така што луѓето (жени и мажи од сите возрасти, услови и позиции) ќе може да уживаат во таквите можности и да имаат придобивки од нив. Тоа значи правда; поточно секој да го добие она што му припаѓ со признавање на посебните услови или карактеристики на секое лице или група луѓе (пол, род, класа, религија, возраст); значи потврдување на разновидноста без да има причина за дискриминација.
Поимник на IUCN

ttps://wwwiucn org/sites/ dev/files/iucn-glossary-ofdefinitions en.pdf
РамноправHOCT

Квалитет да се биде објективен и непристрасен. Начело според кое сите поединци кои се во иста ситуација мора да ги почитуваат истите закони, без каков било вид на разлика или дискриминација

Серија настани со коишто се создаваат промени во

Процес на еволуција генетските фреквенции во рамките на популацијата. Такви промени може да резултираат во појава на нови видови (специјација) или нови интраспециски таксони

Тек

(екосистемски Број на екосистемски услуги што се мобилизираат во услуги) конкретна област и време.
Достапност на храна - достапност на храна која е Достапност на пристапна за сите, безбедна и локално соодветна и храна сигурна од аспект на време и простор - еден од главните проблеми со коишто светот се соочува денес. за правото на животната средина
Поимник на IUCN

https://www.iucn.org/

theme/environmental-law/ our-work/water/water-lawand-governance-supportplatform/learning-resources/ glossary\#PStext

Поимникза

мапирање на екосистемски услуги

и терминологија за

https://oneecosystem.pensoft. net/articles.php?id=27110 оценка

Поимник за

мапирање на екосистемски услуги и терминологија за оценка

Публикација на IUCN од 2016 за Решенија засновани врз природата

https://oneecosystem.pensoft. net/articles.php?id=27110

https://portals.iucn.org/

library/sites/library/files/ documents/2016-036.pdf

Публикација на

IUCN од 2016

за Решенија

засновани врз

природата

(Mansourian et al.

https://portals.iucn.org/ library/sites/library/files/ или деградирани шумски предели. Обновата на шумскиот предел е долготраен процес при кој се враќa еколошката функционалност и се јакне човековата благосостојба во соголените или 2005) \& (Maginnis et деградираните шумски предели.

\section{documents/2016-036 pdf}

\begin{tabular}{llll}
\hline Рамка & Рамка. Структура на високо ниво со која се утврдува \\
заедничката цел и насока за плановите и програмите. & Поимник на IUCN & $\begin{array}{l}\frac{\text { https://www.iucn.org/sites/ }}{\text { dev/files/iucn-glossary-of- }} \\
\text { definitions en.pdf }\end{array}$ \\
\hline
\end{tabular}

Родовите се био-социјално-културни групи, историски изградени од идентификацијата на сексуалните карактеристики со кои луѓето се класифицираат. Откако ќе се класифицираат, им се доделуваат различни групи на функции, активности, општествени односи, форми збир на економски, општествени, правни, политички и психолошки определби и карактеристики, односно dev/files/iucn-glossary-ofdefinitions en.pdf културни, со што се креира она што во секој период на време, општество или култура ќе ги сочинува специфичните содржини на мажот или жената.

Проценето зголемување на GMST (глобалната средна температура) во период од околу 30 години или 30-годишен период центриран на определена година

Глобално или деценија, изразено во однос на прединдустриските затоплување нивоа, освен ако не е поинаку утврдено. За 30-годишните периоди кои се протегаат во минати и идни години, се претпоставува дека продолжува постојниот повеќедецениски тренд на затоплување.

https://www.ipcc.ch/ site/assets/uploads/ sites/2/2019/05/SR15 SPM version report LR.pdf 


\begin{tabular}{|c|c|c|c|}
\hline Термин & Дефиниција & Извор & Врска (линк) \\
\hline Управување & $\begin{array}{l}\text { Активност или начин на управување; систем } \\
\text { за контрола, насочување или регулирање на } \\
\text { влијанието. Вклучува четири аспекти: општествен, } \\
\text { политички, економски и правен. Управувањето, } \\
\text { повеќе од владата, се однесува на збирот на процеси } \\
\text { и институции со кои општеството оспорува, носи и } \\
\text { управува со одлуки. }\end{array}$ & $\begin{array}{l}\text { Поимник на IUCN } \\
\text { за правото на } \\
\text { животната средина }\end{array}$ & $\begin{array}{l}\text { https://www.iucn.org/ } \\
\text { theme/environmental-law/ } \\
\text { our-work/water/water-law- } \\
\text { and-governance-support- } \\
\text { platform/learning-resources/ } \\
\text { glossary\#PStext }\end{array}$ \\
\hline $\begin{array}{l}\text { Тело за } \\
\text { управување }\end{array}$ & $\begin{array}{l}\text { Комитет или одбор кои се одговорни за стратешко } \\
\text { водење на организацијата, ефективно следење на } \\
\text { управувањето и отчетноста на раководството кон } \\
\text { пошироката организација и нејзините засегнати } \\
\text { страни. }\end{array}$ & $\begin{array}{l}\text { Поимник од } \\
\text { Глобалниот } \\
\text { институт за } \\
\text { известување }\end{array}$ & $\frac{\text { https://www.globalreporting. }}{\frac{\text { org/standards/media/1913/ }}{\text { gri-standards-glossary.pdf }}}$ \\
\hline
\end{tabular}

Зелената инфраструктура (ЗИ) се состои од сите природни, полуприродни и вештачки мрежи на мултифункционални еколошки системи во, околу и меѓу урбаните области, на сите просторни нивоа. Концептот за зелена инфраструктура го истакнува квалитетот и квантитетот на урбаните и приградските Публикација на зелени простори, нивната мултифункционална I IUCN од 2016 улога и важноста на меѓусебните поврзувања Зелена м меѓу живеалиштата. ЗИ е стратешки испланирана инфраструк- мрежа на природни и полуприродни области со тура други карактеристики на животната средина кои се дизајнирани и управувани за да обезбедат широк опсег екосистемски услуги. Се инкорпорираат зелените простори (или сини, ако се однесува на водни екосистеми) и други физички карактеристики во копнените (вклучително и крајбрежните) и поморските области. На копно, ЗИ е присутна во рурални и урбани средини.

за Решенија

засновани врз

природата -

(Tzoulas et al.,

https://portals.iucn.org/

library/sites/library/files/ documents/2016-036.pdf
2007) \& (European

Commission, 2013)
Системот за поднесување жалби се состои од постапки, улоги и правила за прием на жалби и обезбедување правни лекови. Забелешка: Од ефективните механизми за жалби се очекува да бидат

Механизам за поднесување жалби легитимни, пристапни, предвидливи, правични, транспарентни, компатибилни со правата и избор на континуирано учење. За механизмите на оперативно ниво да бидат ефективни, се очекува дека ќе бидат засновани врз соработка и дијалог. За опис на секо од овие критериуми, види Водечко начело 31 на Обединетите нации $(\mathrm{OH})$
Поимник од Глобалниот институт за известување https://www.globalreporting org/standards/media/1913/ gri-standards-glossary.pdf

Состојба на целосна физичка, ментална и општествена благосостојба, а не само отсуство на болест или слабост. Здравјето на целата заедница или население се гледа во мерењата на инциденцата и преваленцата на болестите, стапките на смртност поврзани со возраста и очекуваниот животен век.

Човеково здравје Составни делови на благосостојбата: искуствени аспекти на благосостојбата, како што е здравјето, среќата и слободата да се биде и да се прави и, пошироко, основните слободи. Определувачки фактори на благосостојбата: инпут во производство на благосостојба, како што е храна, облека, вода за пиење и пристап до знаење и информации.

\section{Милениумски екосистемски услуги - MEA \\ https://www. millenniumassessment.org/ documents/document.776. aspx.pdf}

„Човековата благосостојба се претпоставува дека има повеќекратни составни делови, вклучително и основен материјал за добар живот, како што се безбедни и соодветни основни средства за живот, доволно храна во секое време, засолниште, облека и пристап до добра; здравје, вклучително и добро да се чувствуваат и да имаат здрава физичка средина, како што е чист воздух и пристап до чиста вода; добри социјални

Човекова односи, вклучително и социјална кохезија, заемна почит и способност да им се помогне на другите и да се обезбедува за децата; безбедност и безбеден пристап до природни и други ресурси, лична безбедност и безбедност од природни катастрофи и катастрофи предизвикани од човекот; и слобода на избор и активност, вклучувајки ја и можноста да се постигне она што поединецот сака да биде и да го прави. 

Дефиниција

Негативни или позитивни влијанија врз поединците,

Влијание општеството и ресурсите од животната средина коишто се резултат од промените во животната средина.
Извор

Поимник за

мапирање на

екосистемски услуги

и терминологија за

оценка
Врска (линк)

https://oneecosystem.pensoft net/articles.php?id=27110

\begin{tabular}{|c|c|c|c|}
\hline $\begin{array}{l}\text { Влијание } \\
\text { (врз животна } \\
\text { средина) }\end{array}$ & $\begin{array}{l}\text { Мерливо влијание на активноста на човекот врз } \\
\text { определен екосистем. Инструментот за мерење е } \\
\text { манифестирањето на влијанието врз животната } \\
\text { средина преку чие документирање се открива } \\
\text { значајното и потенцијалното влијание врз животната } \\
\text { средина кое се генерира од активност или работа, } \\
\text { како и начинот на којшто може да се избегне или да се } \\
\text { намали во случај на негативно влијание. }\end{array}$ & Поимник на IUCN & $\begin{array}{l}\frac{\text { https://www.iucn.org/sites/ }}{\text { dev/files/iucn-glossary-of- }} \\
\underline{\text { definitions en.pdf }}\end{array}$ \\
\hline Спроведување & $\begin{array}{l}\text { Со спроведувањето се опишуваат активностите } \\
\text { кои се преземаат за да се исполнат обврските } \\
\text { во рамки на договорот и се опфаќат правните } \\
\text { и ефективните фази. Правното спроведување се } \\
\text { однесува на законска регулатива, прописи, судски } \\
\text { уредби, вклучително и други активности како што се } \\
\text { напорите за управување со напредокот на владите } \\
\text { во насока на пренесување на меѓународните } \\
\text { договори во националното право и политика. За } \\
\text { ефективното спроведување се потребни политики } \\
\text { и програми со коишто се воведуваат промени во } \\
\text { однесувањето и одлуките на целните групи. Потоа } \\
\text { целните групи ги преземаат ефективните мерки на } \\
\text { ублажување и приспособување. Види и Усогласеност. }\end{array}$ & IPCC & $\begin{array}{l}\text { https://www.ipcc.ch/pdf/ } \\
\text { assessment-report/ar4/syr/ } \\
\underline{\text { ar4 syr appendix.pdf }}\end{array}$ \\
\hline Показател & $\begin{array}{l}\text { Квантитативен или квалитативен фактор } \\
\text { или променлива со коишто се обезбедуваат } \\
\text { едноставни и веродостојни средства за мерење на } \\
\text { постигнувањето на резултатите, за одразување на } \\
\text { промените поврзани со системот на стандарди или } \\
\text { за да се помогне во проценката на успешноста на } \\
\text { организацијата. }\end{array}$ & $\begin{array}{l}\text { Поимник на } \\
\text { термини на ISEAL } \\
\text { - приспособено } \\
\text { од Поимникот на } \\
\text { ОЕЦД, } 2002 .\end{array}$ & $\begin{array}{l}\text { https://www. } \\
\text { sustainabilityxchange. } \\
\frac{\text { info/filesagri//SEAL } \% 20}{\text { Glossary\%20of\%20Terms\%20 }} \\
\underline{\text { v1\%20-02016\%20Jan\%20 }}\end{array}$ \\
\hline $\begin{array}{l}\text { Автохтоно } \\
\text { знаење }\end{array}$ & $\begin{array}{l}\text { Знаење кое е единствено за определена култура или } \\
\text { општество. Види традиционално знаење. }\end{array}$ & $\begin{array}{l}\text { Милениумски } \\
\text { екосистемски услуги } \\
\text { - МЕA }\end{array}$ & $\begin{array}{l}\frac{\text { https://www. }}{\text { millenniumassessment.org/ }} \\
\text { documents/document.776. } \\
\text { aspx.pdf }\end{array}$ \\
\hline
\end{tabular}

\begin{tabular}{|c|c|c|c|}
\hline $\begin{array}{l}\text { Домородни } \\
\text { народи }\end{array}$ & $\begin{array}{l}\text { Постојните наследници на луѓето кои ја населувале } \\
\text { постојната територија на земја, целосно или делумно, } \\
\text { во времето кога лицата од друга култура или етничко } \\
\text { потекло пристигнале таму од други делови од светот, } \\
\text { ги совладале и, со освојување, населување или други } \\
\text { средства ги намалиле на недоминатна или колонијална } \\
\text { ситуација; кои денес живеат повеке во согласност со } \\
\text { своите општествени, економски и културни обичаи } \\
\text { и традиции отколку со институциите на земјата од } \\
\text { која сега се дел, во рамките на државна структура која } \\
\text { главно ги инкорпорира националните, општествените } \\
\text { и културните карактеристики на другите сегменти од } \\
\text { населението кое е доминантно. (Работна дефиниција } \\
\text { усвоена од Работната група на ОН за домородни } \\
\text { народи). }\end{array}$ & Поимник на IUCN & $\begin{array}{l}\frac{\text { https://www.iucn.org/sites/ }}{\text { dev/files/iucn-glossary-of- }} \\
\text { definitions en.pdf }\end{array}$ \\
\hline $\begin{array}{l}\text { Инфраструк- } \\
\text { тура }\end{array}$ & $\begin{array}{l}\text { Основна опрема, комуналии, производствени } \\
\text { претпријатија, инсталации и услуги коишто се } \\
\text { основни за развојот, работењето и растот на една } \\
\text { организација, град или нација. }\end{array}$ & IPCC & $\begin{array}{l}\text { https://www.ipcc.ch/pdf/ } \\
\text { assessment-report/ar4/syr/ } \\
\underline{\text { ar4 syr appendix.pdf }}\end{array}$ \\
\hline Институции & $\begin{array}{l}\text { Институциите се трајни, предвидливи аранжмани, } \\
\text { закони, процеси или обичаи коишто служат да } \\
\text { се структурираат политичките, општествените, } \\
\text { културните или економските трансакции и односи } \\
\text { во општеството. Тие може да бидат неформални } \\
\text { или формални и овозможуваат организирани, } \\
\text { колективни напори за општи прашања. Иако се } \\
\text { трајни, институциите постојано се развиваат. }\end{array}$ & $\begin{array}{l}\text { Поимник на IUCN } \\
\text { за правото на } \\
\text { животната средина }\end{array}$ & $\begin{array}{l}\text { https://www.iucn.org/ } \\
\text { theme/environmental-law/ } \\
\text { our-work/water/water-law- } \\
\text { and-governance-support- } \\
\text { platform/learning-resources/ } \\
\text { glossary\#PStext }\end{array}$ \\
\hline
\end{tabular}


Метод на анализа со којшто се комбинираат

резултатите и моделите од физичките, биолошките, економските и општествените науки и интеракциите Интегрирана меѓу овие компоненти во една конзистентна рамка оценка за да се оцени статусот и последиците од промените во животната средина и политичките одговори на истото. Моделите што се користат за да се спроведе таква анализа се нарекуваат Модели за интегрирана оценка.

IPCC $\frac{\text { https://www.ipcc.ch/pdf/ }}{\text { assessment-report/ar4/syr/ }}$
ar4 syr appendix.pdf

\section{Поимник за}

мапирање на

екосистемски услуги

и терминологија за

оценка

https://oneecosystem.pensoft. net/articles.php?id=27110 i) комбинирање, іi) толкување и іiі) соопштување на знаењето од различни дисциплини.
Внесени видови се оние кои се јавуваат надвор од нивниот природен ареал (минат или сегашен) и потенцијал за ширење (т.е. надвор од ареалот што природно го населуваат или не може да го населуваат без директно или индиректно внесување или грижа од страна на луѓето).

\section{RLTS Поимник $\quad$ org/initiatives/mammals/ description/glossary}

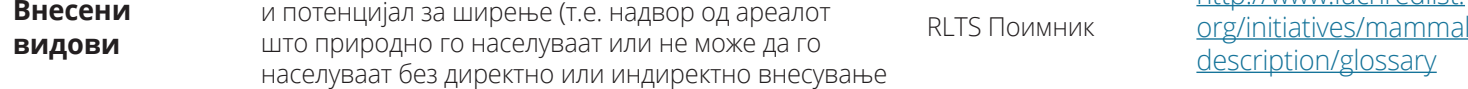

Туѓи видови се видови кои се внесени од луѓето намерно или случајно - надвор од нивното природно минато или сегашно распространување; сепак, сите туѓи видови немаат негативно влијание и се проценува дека од 5 \% до 20 \% од сите туѓи видови стануваат проблематични. Токму тие видови се нарекуваат

Инвазивни видови инвазивни туѓи видови (ИТВ). „Инвазивни туѓи видови (ИТВ) се видови кои се јавуваат надвор од своето природно минато или сегашно распространување чие воведување и/или ширење й се заканува на биолошката разновидност" Конвенција за биолошка разновидност.
RLTS Поимник

http://www.iucnredlist. org/initiatives/mammals/ description/glossary
Употребата на земјиште се однесува на начинот на

Употреба на земјиште употреба на конкретно парче земја: целта, потребата или употребата (на пр., земјоделство, индустрија, станбена или природна).
Поимник од пакетот алатки за КБР

\section{https://www.cbd.int/cepa/ toolkit/2008/doc/CBD-Toolkit-} Glossaries.pdf

Поимник за

мапирање на

екосистемски услуги

и терминологија за

Предел ултурни имоти што ја претставуваат комбинираната

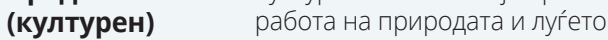

https://oneecosystem.pensoft. net/articles.php?id=27110
Област, гледано од перспектива на луѓето, чија природа е резултат од активноста и интеракцијата на природните и/или човечките фактори. Следствено, терминот „предел“ се дефинира како зона или област гледано од перспектива на локалното население или посетителите, чии визуелни карактеристики и

Предел (географски) или културните фактори. Се потврдува фактот дека пределите се развиваат со текот на времето и се резултат од природните и човечките активности. Пределот треба да се смета за целина - природните и културните компоненти се земаат заедно, а не одвоено.

/

\section{Поимник за}

мапирање на

екосистемски услуги

и терминологија за

оценка https://oneecosystem.pensoft. net/articles.php?id=27110

\section{Пристапот на предел се заснова врз нов пакет} начела со кои се истакнува приспособливото

Пристап на предел управување, вклученоста на заинтересираните страни и повеќекратните цели за решавање на општествените прашања во врска со животната средина и развојните компромисни решенија.

Поврзаност на предел на организмите и нивните гени и се соочув со клучни закани од фрагментација и загуба на живеалишта.
Rudnick et al., 2012

https://www.fs.fed.us/rm/ pubs other/rmrs 2012 rudnick d001.pdf 


\begin{tabular}{|c|c|c|c|}
\hline Термин & Дефиниција & Извор & Врска (линк) \\
\hline Тек на предел & $\begin{array}{l}\text { Тек на пределот - размени што настануваат на ниво } \\
\text { кое е поголемо од местото (вклучително и водните } \\
\text { средини) и вклучително текот на енергија, вода, оган и } \\
\text { генетски материјал. Поврзувањата на живеалиштата ја } \\
\text { олеснуваат размената. (Wiens 1992) }\end{array}$ & $\begin{array}{l}\text { Меѓународни } \\
\text { стандарди за } \\
\text { праксата на } \\
\text { еколошка обнова } \\
\text { - вклучувајќи } \\
\text { ги и начелата и } \\
\text { клучните концепти }\end{array}$ & $\begin{array}{l}\text { http://seraustralasia. } \\
\text { com/wheel/image/SER } \\
\underline{\text { International Standards.pdf }}\end{array}$ \\
\hline
\end{tabular}

Нема една прифатена дефиниција за „обем на предел"; туку тоа е термин што обично се користи за активност со која се опфаќа голем просторен обем и обично се разгледува опсег на екосистемски процеси, цели за зачувување и употреби на земјиште. Во „вистинскиот обем" може да треба да се земат предвид конкретните интереси за оние коишто се вклучени локално, естетски или културни карактеристики, природни карактеристики како што се речните сливови или конкретни живеалишта или потврдени области, како што се 159те Области од национален карактер. Зачувувањето на обемот на пределот се карактеризира со следење на обем на повеќекратните придобивки во рамките на утврдена предел област (на пример, квалитет на водата, биодиверзитет и пристап). Кај најдобрите примери има и поврзаност со пошироките економски и општествени приоритети, каде што со јакнењето на природата може да се обезбедат придобивки за локалната економија и квалитетот на живеење. Има силна поврзаност меѓу пристапот на обем на предел и „пристапот на екосистем“, со којшто се поттикнува интегриран пристап кон управувањето со земјиштето, земајки ги предвид трошоците и придобивките од одлуките за употреба на земјиште и следење на оние со кои се минимизираат ризиците и се максимизираат можностите за луѓето, за природата и за економијата.

Обем на предел - кон интегриран пристап; Природен извор, Бела книга за природна животна средина, 2011 https://www.banc.org.uk/wpcontent/uploads/2015/05/ ECOS-33-3-4-6-Landscapescale-integrated-approach.pdf
Последователни и поврзани фази на производ (добра или услуги), од употребата на природните ресурси до конечното одложување.
Поимник на УНДП - приспособен од ИСО 14040:2006 https://www.unenvironment. org/explore-topics/resourceefficiency/why-does-resourceefficiency-matter/glossary

\section{циклус}

Лобирање или јавни работи се специјализирана форма на односи со јавноста. Се однесува на активностите кои се насочени кон градење и одржување неформални односи со формални носители на одлуки. Неформалните односи се користат за да се влијае врз процесите за алатки за КБР

https://www.cbd.int/cepa/

Лобирање одлучување во интерес на организацијата, нејзината програма и/или цели.

\begin{tabular}{|c|c|c|c|}
\hline $\begin{array}{l}\text { Локално } \\
\text { знаење }\end{array}$ & Види автохтоно или традиционално знаење. & - & - \\
\hline Интегрирање & $\begin{array}{l}\text { Вградување конкретно прашање, на пример } \\
\text { одржливо користење на екосистеми, во политики и } \\
\text { активности }\end{array}$ & $\begin{array}{l}\text { Милениумски } \\
\text { екосистемски услуги } \\
\text { - МЕA }\end{array}$ & $\begin{array}{l}\frac{\text { https://www. }}{\text { millenniumassessment.org/ }} \\
\text { documents/document.776. } \\
\underline{\text { aspx.pdf }}\end{array}$ \\
\hline Одржување & $\begin{array}{l}\text { Одржување екосистеми - тековни активности - } \\
\text { кои се применуваат по целосното обновување } \\
\text { - предвидено за спречување на процесите на } \\
\text { еколошка деградација за да се одржат атрибутите на } \\
\text { екосистемот. Веројатно ке биде потребно повисоко } \\
\text { тековно одржување на обновените места каде } \\
\text { што и понатаму има повисоки нивоа на закани, } \\
\text { во споредба со местата каде што заканите се } \\
\text { контролирани (McDonald et al. 2016). }\end{array}$ & $\begin{array}{l}\text { Меѓународни } \\
\text { стандарди за } \\
\text { праксата на } \\
\text { еколошка обнова } \\
\text { - вклучувајќи } \\
\text { ги и начелата и } \\
\text { клучните концепти }\end{array}$ & $\begin{array}{l}\frac{\text { http://seraustralasia. }}{\text { com/wheel/image/SER }} \\
\underline{\text { International Standards.pdf }}\end{array}$ \\
\hline
\end{tabular}


Мерки што овозможуваат активност со негативно влијание врз биодиверзитетот, но го намалуваат влијанието врз местата со земање предвид на промените на обемот, дизајнот, локацијата, процесот, редоследот, управувањето и/или следењето на предложената активност. Бара заеднички напори на

Ублажување планерите, инженерите, еколозите, други експерти и често на локалните заинтересирани страни за да се изнајде најдоброто решение за животната средина. Пример е неприфатливото влијание врз биодиверзитетот од изградбата на определен пат, што се ублажува преку изградба на природен вијадукт.
Поимник од пакетот алатки за КБР https://www.cbd.int/cepa/ toolkit/2008/doc/CBD-ToolkitGlossaries.pdf

\begin{tabular}{|c|c|c|c|}
\hline $\begin{array}{l}\text { Следење } \\
\text { (мониторинг) }\end{array}$ & $\begin{array}{l}\text { Редовно, статистички дизајнирано броење на } \\
\text { популацијата за да се следи нејзиниот број, состав и } \\
\text { распространување }\end{array}$ & Поимник на IUCN & $\frac{\text { https://www.iucn.org/sites/ }}{\text { dev/files/iucn-glossary-of- }}$ \\
\hline $\begin{array}{l}\text { Следење и } \\
\text { евалуација }\end{array}$ & $\begin{array}{l}\text { Тековен процес преку којшто организацијата } \\
\text { извлекува заклучоци за неговиот придонес кон } \\
\text { предвидените резултати и влијанија. Системот } \\
\text { за следење и евалуација содржи пакет мегусебно } \\
\text { поврзани функции, процеси и активности, } \\
\text { вклучително и систематско собирање на податоците } \\
\text { од следењето на наведените показатели и } \\
\text { спроведувањето на евалуациите на резултатот и } \\
\text { влијанието. }\end{array}$ & Поимник на ISEAL & $\begin{array}{l}\text { https://www. } \\
\text { sustainabilityxchange. } \\
\frac{\text { info/filesagri/ISEAL } \% 20}{\text { Glossary\%20of\%20Terms\%20 }} \\
\underline{\text { v1\%20-02016\%20Jan\%20 }}\end{array}$ \\
\hline
\end{tabular}

\begin{tabular}{|c|c|c|c|}
\hline $\begin{array}{l}\text { Национални } \\
\text { обврски }\end{array}$ & $\begin{array}{l}\text { Национална стратегија за биодиверзитет и акциски } \\
\text { план. Со Конвенцијата за биолошка разновидност } \\
\text { од сите страни кон истата се бара да се изготви } \\
\text { Национална стратегија за биодиверзитет и акциски план } \\
\text { (Член ба), со која се утврдуваат конкретни активности и } \\
\text { цели за постигнување на целите од Конвенцијата. Овие } \\
\text { планови најчесто се спроведуваат со партнерство на } \\
\text { организации за зачувување на природата. Видовите } \\
\text { или живеалиштата што се предмет на НСБАП се } \\
\text { владини наведени приоритети за активност и затоа } \\
\text { има зголемена загриженост кога се под закана. НСБАП } \\
\text { немаат правен статус, а видовите од листата и видовите } \\
\text { живеалишта не секогаш се заштитени (иако дел од нив } \\
\text { се покриени со друга законска регулатива). }\end{array}$ & $\begin{array}{l}\text { Поимник од пакетот } \\
\text { алатки за КБР }\end{array}$ & $\begin{array}{l}\frac{\text { https://www.cbd.int/cepa/ }}{\text { toolkit/2008/doc/CBD-Toolkit- }} \\
\underline{\text { Glossaries.pdf }}\end{array}$ \\
\hline
\end{tabular}

Локални автохтони екосистеми - екосистем што се состои од видови или подвидови (вклучуваіќи инвазивни неавтохтони видови) за кои е познато дека локално се развиле или кои неодамна мигрирале од соседните локалитети поради менувањето на климата. Онаму каде што недостасуваат локални докази, регионалните и историските информации може да помогнат за утврдувањето на најверојатните локални автохтони екосистеми. Тие се разликуваат од „културните екосистеми" (на пр., агроекосистеми) ако екосистемите се значително модифицирани до степен и конфигурација кои се надвор од природната аналогија или се надвор од ареалот на природна варијација за тој екосистем.

\author{
Меѓународни \\ стандарди за \\ праксата на \\ еколошка обнова \\ - вклучувајќ́ \\ ги и начелата и \\ клучните концепти
}

http://seraustralasia.

com/wheel/image/SER

International Standards.pdf

Природната животна средина се состои од сите живи и неживи работи кои природно се јавуваат на Земјата. Во најчиста смисла, тоа е животна средина која не е резултат од интервенција или активност на човекот. Природната средина може да се стави наспроти „изградената средина“ и е во контраст со концептот за културен предел.

Природно

Природната инфраструктура (ПИ) се дефинира како „стратешки испланирана и управувана

Природна
инфраструк-
тура
мрежа на природно земјиште, како што се шуми и водни живеалишта, работни предели и други отворени простори со кои се зачувуваат или јакнат екосистемските вредности и функции и се обезбедуваат придружните придобивки за човечката популација".
Поимник од пакетот алатки за КБР

https://www.cbd.int/cepa/ toolkit/2008/doc/CBD-ToolkitGlossaries.pdf

$\begin{array}{ll}\text { Публикација на } & \\ \text { IUCN од 2016 } & \\ \text { за решенија } & \underline{\text { https://portals.iucn.org/ }} \\ \text { засновани врз } & \underline{\text { library/sites/library/files/ }} \\ \text { природната - } & \underline{\text { documents/2016-036.pdf }} \\ \text { Benedict \& cMahon, } \\ \text { 2006) }\end{array}$




\begin{tabular}{|c|c|c|c|}
\hline Термин & Дефиниција & Извор & Врска (линк) \\
\hline $\begin{array}{l}\text { Животен } \\
\text { циклус на РЗП }\end{array}$ & $\begin{array}{l}\text { Концепт } \\
\text { Развој } \\
\text { Спроведување и следење } \\
\text { Евалуација } \\
\text { Завршување }\end{array}$ & IUCN PAAS & $\begin{array}{l}\text { https://www.iucn.org/ } \\
\text { resources/project- } \\
\text { management-tools/project- } \\
\text { guidelines }\end{array}$ \\
\hline Можности & $\begin{array}{l}\text { Тоа се можности за развој на интелектуалните, } \\
\text { физичките и емоционалните способности за да се } \\
\text { следат и да се постигнат утврдените животни цели. }\end{array}$ & Поимник на IUCN & $\begin{array}{l}\frac{\text { https://www.iucn.org/sites/ }}{\text { dev/files/iucn-glossary-of- }} \\
\text { definitions en.pdf }\end{array}$ \\
\hline Исходи & $\begin{array}{l}\text { Еколошки или општествени услови на терен } \\
\text { кои се директна последица од резултатите и кои } \\
\text { придонесуваат кон предложеното влијание. На } \\
\text { пример, водно тело заштитено од стока, промена на } \\
\text { површината на шума со која одржливо се управува } \\
\text { (што е резултат од подобреното знаење преку обука), } \\
\text { намалување на седиментацијата и ерозијата (што е } \\
\text { резултат од садење на падините). }\end{array}$ & $\begin{array}{l}\text { Постапка за } \\
\text { екосистемски } \\
\text { услуги: Приказ на } \\
\text { влијанија и пазарни } \\
\text { алатки }\end{array}$ & $\begin{array}{l}\text { https://ic.fsc.org/file- } \\
\text { download.ecosystem-services- } \\
\text { procedure.a-7433.pdf }\end{array}$ \\
\hline Резултати & $\begin{array}{l}\text { Непосредни и директни последици од активностите } \\
\text { за управување кои се спроведуваат на ниво на } \\
\text { единицата за управување. На пример, метри } \\
\text { изградена ограда, број на обучени лица и број } \\
\text { на насадени хектари на падини, сооднос на } \\
\text { единицата за управување од каде што се отстранети } \\
\text { егзотичните видови. }\end{array}$ & $\begin{array}{l}\text { Постапка за } \\
\text { екосистемски } \\
\text { услуги: Приказ на } \\
\text { влијанија и пазарни } \\
\text { алатки }\end{array}$ & $\begin{array}{l}\text { https://ic.fsc.org/file- } \\
\text { download.ecosystem-services- } \\
\text { procedure.a-7433.pdf }\end{array}$ \\
\hline $\begin{array}{l}\text { Партиципа- } \\
\text { тивно } \\
\text { истражување } \\
\text { на активност }\end{array}$ & $\begin{array}{l}\text { Партиципативното истражување на активноста } \\
\text { (ПИА) е пристап на истражување кој се користи } \\
\text { од 1940-те. Вклучува истражувачи и учесници кои } \\
\text { заедно работат за да разберат некоја проблематична } \\
\text { ситуација и да ја променат на подобро. Има многу } \\
\text { дефиниции за пристапот што имаат заеднички } \\
\text { елементи. ПИА се фокусира врз општествена } \\
\text { промена со која се промовира демократијата и се } \\
\text { оспорува нееднаквоста; специфична е за контекстот, } \\
\text { често ги има за цел потребите на определена група; } \\
\text { претставува повторлив циклус на истражување, } \\
\text { активност и рефлексија; и често бара „ослободувањее } \\
\text { на учесниците за да имаат поголема свесност за } \\
\text { својата ситуација со цел да преземат активност. ПиА } \\
\text { користи опсег на различни методи, квалитативни и } \\
\text { квантитативни. }\end{array}$ & $\begin{array}{l}\text { Институт за } \\
\text { развојни студии }\end{array}$ & $\begin{array}{l}\text { https://www. } \\
\text { participatorymethods.org/ } \\
\text { glossary-terms }\end{array}$ \\
\hline $\begin{array}{l}\text { Партиципа- } \\
\text { тивно учење и } \\
\text { активност }\end{array}$ & $\begin{array}{l}\text { Партиципативното учење и активност претставува } \\
\text { семејство од пристапи, методи, ставови, однесувања } \\
\text { и односи, кои овозможуваат и ги јакнат луѓето да } \\
\text { го споделат, да го анализираат и да го зајакнат } \\
\text { своето познавање за својот живот и услови и } \\
\text { за да планираат, делуваат, следат, евалуираат и } \\
\text { рефлектираат. }\end{array}$ & $\begin{array}{l}\text { Институт за } \\
\text { развојни студии }\end{array}$ & $\begin{array}{l}\text { https://www. } \\
\text { participatorymethods.org/ } \\
\text { glossary-terms }\end{array}$ \\
\hline Политика & $\begin{array}{l}\text { Општи начела со коишто се води владата во своето } \\
\text { управување со јавните работи. Тек или начело на } \\
\text { активност кое е усвоено или предложено од страна } \\
\text { на организација или поединец. }\end{array}$ & $\begin{array}{l}\text { Поимник на IUCN } \\
\text { за правото на } \\
\text { животната средина }\end{array}$ & $\begin{array}{l}\text { https://www.iucn.org/ } \\
\text { theme/environmental-law/ } \\
\text { our-work/water/water-law- } \\
\text { and-governance-support- } \\
\text { platform/learning-resources/ } \\
\text { glossary\#PStext }\end{array}$ \\
\hline $\begin{array}{l}\text { Прединдус- } \\
\text { триски }\end{array}$ & $\begin{array}{l}\text { Повеќевековен период пред појавата на големата } \\
\text { индустриска активност околу } 1750 \text { година. } \\
\text { Референтниот период 1850-1900 се користи за } \\
\text { определување на прединдустриските GMST. }\end{array}$ & Извештај на ИПЦЦ & $\begin{array}{l}\frac{\text { https://www.ipcc.ch/ }}{\text { site/assets/uploads/ }} \\
\text { sites/2/2019/05/SR15 SPM } \\
\text { version_report_LR.pdf }\end{array}$ \\
\hline Проект & $\begin{array}{l}\text { Проект е временски определен пакет активности } \\
\text { дизајнирани за постигнување резултати и } \\
\text { обезбедување влијанија. }\end{array}$ & IUCN PAAS & $\begin{array}{l}\text { https://www.iucn.org/ } \\
\text { resources/project- } \\
\text { management-tools/project- } \\
\text { guidelines }\end{array}$ \\
\hline
\end{tabular}


Дизајнирањето на соодветна проектна организација за определен проект може да се смета за клучен фактор за успех на проектот. За проектите се потребни соодветни организациски дизајни вклучително и улоги како што е сопственик на

Дизајн на проект проектот; проектен раководител, членови на проектен тим, проектни тимови и под-тимови. Понатаму, проектната организација мора да биде поврзана со проектната извршна компанија или компании. Централните методи за проектно управување се проектниот органограм и описот на проектните улоги.
Поврзување на одржливиот развој и проектното управување: концептуален модел - (Gareis, 2005) https://www.pmi.org/learning/ library/relating-sustainabledevelopment-projectmanagement-6497

Потенцијална идна еволуција на квантитет или збир од количества, кои се често пресметувани со помош на модел. Проекциите се разликуваат од

Проекција предвидувањата за да се истакне дека проекциите вклучуваат предвидувања поврзани со, на пример, идниот социоекономски и технолошки развој што

https://www.ipcc.ch/pdf/ assessment-report/ar4/syr/ ar4 syr appendix.pdf значителна несигурност.

IUCN ја дефинира заштитената област како: „асно дефиниран географски простор, признаен, наменет и управуван преку правни или други ефективни средства за да се постигне долгорочно зачувување

Заштитена област на природата со поврзаните екосистемски услуги и културни вредности" (Dudley, 2008). Ефективната заштита може, исто така, да се случува на друго место, а IUCN води процес за дефинирање на „другите ефективни механизми за зачувување засновани на областа" како потврда на истото (Jonas et al., 2014)

\begin{tabular}{|c|c|c|c|}
\hline $\begin{array}{l}\text { Услуги за } \\
\text { обезбедување }\end{array}$ & $\begin{array}{l}\text { Производ што се добива од екосистемите } \\
\text { вклучувајќ, на пример, генетски извори, храна и } \\
\text { влакна и вода за пиење. }\end{array}$ & $\begin{array}{l}\text { Милениумски } \\
\text { екосистемски услуги } \\
\text { - МЕА }\end{array}$ & $\begin{array}{l}\text { https://www. } \\
\frac{\text { millenniumassessment.org/ }}{\text { documents/document.776. }} \\
\text { aspx.pdf }\end{array}$ \\
\hline $\begin{array}{l}\text { Услуги за } \\
\text { регулирање }\end{array}$ & $\begin{array}{l}\text { Придобивките што се добиени од регулацијата на } \\
\text { екосистемските процеси вклучувајки, на пример, } \\
\text { регулирање на климата, на водата и на определени } \\
\text { болести на човекот. }\end{array}$ & $\begin{array}{l}\text { Милениумски } \\
\text { екосистемски услуги } \\
\text { - МЕA }\end{array}$ & $\begin{array}{l}\frac{\text { https://www. }}{\text { millenniumassessment.org/ }} \\
\text { documents/document.776. } \\
\text { aspx.pdf }\end{array}$ \\
\hline $\begin{array}{l}\text { Отпорност } \\
\text { (екосистем) }\end{array}$ & $\begin{array}{l}\text { Отпорност на екосистем - капацитет на системот да } \\
\text { го апсорбира нарушувањето и да се реорганизира } \\
\text { притоа задржувајќ ја сличната функција, структура } \\
\text { и повратни информации. Кај растителните и } \\
\text { животинските заедници ова својство значително } \\
\text { зависи од приспособувањата на поединечните } \\
\text { видови кон нарушувањата или стресовите со кои се } \\
\text { соочиле во текот на еволуцијата на видовите. }\end{array}$ & $\begin{array}{l}\text { Меѓународни } \\
\text { стандарди за } \\
\text { праксата на } \\
\text { еколошка обнова } \\
\text { - вклучувајќи } \\
\text { ги и начелата и } \\
\text { клучните концепти }\end{array}$ & $\begin{array}{l}\text { http://seraustralasia. } \\
\text { com/wheel/image/SER } \\
\text { International Standards.pdf }\end{array}$ \\
\hline $\begin{array}{l}\text { Отпорност } \\
\text { (општо) }\end{array}$ & $\begin{array}{l}\text { Способност на општествениот или на еколошкиот } \\
\text { систем да ги апсорбира нарушувањата притоа } \\
\text { задржувајќ ја истата основна структура и } \\
\text { начините на функционирање, капацитетот } \\
\text { за самоорганизирање и капацитетот за } \\
\text { приспособување кон стресот и промената. }\end{array}$ & IPCC & $\begin{array}{l}\text { https://www.ipcc.ch/pdf/ } \\
\text { assessment-report/ar4/syr/ } \\
\text { ar4 syr appendix.pdf }\end{array}$ \\
\hline $\begin{array}{l}\text { Ресурси } \\
\text { (биолошки) }\end{array}$ & $\begin{array}{l}\text { Биолошки ресурси. Генетски ресурси, организми } \\
\text { или делови од нив, популации или која било друга } \\
\text { биотичка компонента на екосистемите со реална или } \\
\text { потенцијална вредност или употреба за човековите } \\
\text { суштества. Пристап: се дефинира како можност за } \\
\text { учество, искористување и придобивка. }\end{array}$ & Поимник на IUCN & $\begin{array}{l}\text { https://www.iucn.org/sites/ } \\
\text { dev/files/iucn-glossary-of- } \\
\text { definitions en.pdf }\end{array}$ \\
\hline
\end{tabular}

Заштитени области според IUCN

https://www.iucn.org/theme/ protected-areas/about 
Природни ресурси. Природните ресурси често се класифицираат на обновливи и необновливи ресурси. Обновливите ресурси се генерално живите ресурси (на пример, риба, кафе и шуми), кои може самите да се обноват ако не се искористуваат прекумерно. Обновливите ресурси можат самите да се обновуваат и може бесконечно да се користат ако е користењето одржливо. Кога обновливите ресурси се користат по стапка која е повисока од нивната природна стапка на замена, залихите ќe ce намалат и може да се исцрпат. Стапката на одржливо користење на обновлив извор се определува со стапката на замена и количеството залихи на конкретниот ресурс. Неживите обновливи природни ресурси вклучуваат почва, како и вода,

Ресурси ветер, плима и осека и соларно зрачење - споредено (природни) со обновливата енергија. Ресурсите може да се класифицираат и врз основа на нивното потекло како биотички и абиотички. Биотичките ресурси се добиваат од животните и растенијата (т.е. живиот свет). Абиотичките ресурси се добиваат од неживиот свет, на пример од земјата, водата и воздухот. Минералните и енергетските ресурси се исто така абиотички ресурси, од кои некои се добиваат од природата. Извлекувањето на основниот ресурс и неговата обработка во почиста, директно употреблива форма (на пример, метали, рафинирани масла) генерално се сметаат за активности со природни ресурси иако вторите не секогаш се јавуваат блиску до првите. Природните ресурси се природен капитал претворен во производни инпути за инфраструктурните капитални процеси.
Поимник од пакетот алатки за КБР

https://www.cbd.int/cepa/ toolkit/2008/doc/CBD-ToolkitGlossaries.pdf

\section{Обновување Обнова на структурата, функцијата и процесите на} (реставрација) првичниот екосистем.

Исходи, резултати и влијанија што се резултат од спроведувањето на системот стандарди (приспособено од Поимникот на ОЕЦД, 2002).
Поимник на IUCN

https://www.iucn.org/sites/ dev/files/iucn-glossary-ofdefinitions en.pdf

https://www. sustainabilityxchange. info/filesagri/ISEAL \%20

Поимник на ISEAL Glossary\%20of\%20Terms\%20 v1\%20-\%2016\%20Jan\%20 2015.pdf
Проектниот ризик може да се опише како „можност за негативно или позитивно отстапување од проектната цел“. Поради тоа, ризиците може да влијаат врз успехот на проектот и со нив треба соодветно да се управува.
Поврзување на одржливиот развој и проектното управување: концептуален модел (Gareis, 2005) https://www.pmi.org/learning/ library/relating-sustainabledevelopment-projectmanagement-6497

\section{Концепт на}

скалабилност: зголемување на степенот и потенцијално усвојување на интервенциите

https://www.ncbi.nlm.nih.gov/ овој процес, скалабилноста се дефинира способност на интервенцијата која се покажала како ефикасна на понизок степен и/или во контролирани услови да се прошири во реални услови за да допре до поголем сооднос од соодветната популација, притоа задржувајќи ја ефективноста.

со коишто се

промовира

здравјето во

политиката и

практиката.

\section{pubmed/22241853}

Мерливи димензии на појави или опсервации. Се изразува во физички единици, како што се метри, години, големина на популација или количества што се преместуваат или се разменуваат. При опсервација, со степенот се утврдува релативната финост и грубост на различните детали и селективноста меѓу шемите коишто овие податоци може да ги формираат.

Милениумски екосистемски услуги - MEA https://www.

millenniumassessment.org/ documents/document.776. aspx.pdf 
Сразмерното зголемување се дефинира како "проширување, реплицирање, приспособување и одржување на успешните политики, програми или проекти во географски простор и во временски период за да се допре до поголем број луѓе. „Важно е однапред да се утврди крајниот степен до којшто интервенцијата треба или може да се доведе, имајќи

Сразмерно зголемување ги предвид потребите на целната популација и природата на интервенцијата. Исто така, важно е реалистично да се земе предвид временскиот хоризонт во рамките на којшто процесот на сразмерно зголемување треба да се прошири за да се постигне посакуваниот краен степен. Хартман и Лин утврдија дека за успешното зголемување на програмите на национално ниво може да бидат потребни од десет до петнаесет години, или подолго.
Иновации според default/files/documents/1865/ степен: Методи, v5web R4D MSI-

примени и лекции BrookingsSynthPaper0914-3. $\underline{\mathrm{pdf}}$
Сразмерното зголемување се постигнува со: учество во процесите за одлучување и активности; осознавање кои промени се потребни и изводливи; односи и мрежи со коишто се шират идеи и се

Сразмерно зголемување инспирираат активности. Со учеството, учењето $и$ односите се генерираат работни интервенции што ги исполнуваат локалните потреби и сопственоста на заинтересираните страни. Ова води кон одржливост и зголемување на резултатите.
Burns, D., and

Worsley, S., 2015

Навигација во

сложеноста во меѓународниот развој, Рагби ОК, (Rugby, UK): Practical http:// dx.doi.org/ 10.3362/ Action Publishing
9781780448510

Програмата за меѓународно оценување на учениците (PISA) ја дефинира научната писменост како капацитет за употреба на научното знаење,

Научно знаење идентификување прашања и извлекување заклучоци засновани врз докази за да се разберат и да се донесат одлуки за природниот свет и за неговите промени преку активноста на човекот.

ОЕцД $\quad \frac{\text { https://stats.oecd.org/ }}{\text { glossary/search.asp }}$

Под-оддел од економијата, општеството или сферата Поимник на на активност, дефинирано врз основа на некои општи карактеристики.

Глобалниот институт за известување

https://www.globalreporting org/standards/media/1913/ gri-standards-glossary.pdf

\section{Меѓународни}

стандарди за

праксата на hattp://seraustralasia.

Одвоено место или локација. Може да се јават на различни степени, но генерално на исечок или степен на имот (т.е. помало од предел).
com/wheel/image/SER International Standardspdf еколошка обнова

- вклучувајќи

ги и начелата и

клучните концепти

Општествен капитал. Се состои, во тесна смисла на зборот, од општествени мрежи и поврзани норми коишто имаат влијание врз продуктивноста на заедницата. Вкоренет е во довербата и е она со кое

Општествени се олеснува соработката и координацијата за заемна услови корист на членовите на групата. Во поширока смисла, терминот опфаќа вертикални и хоризонтални

Поимник на IUCN https://www.iucn.org/sites/ здруженија, меѓу заедници и други групи како што се шумарските агенции, групите за сертифицирање шуми, општински совети, итн.

Група единки кои имаат заеднички карактеристики и меѓусебно се размножуваат и создаваат плодно (способно за размножување) потомство и кои не

Видови може да се размножуваат со други такви групи, поточно со популација која е репродуктивно изолирана од другите; поврзаните видови се

Поимникна IUCN https://www.iucn.org/sites/ групирани во родови, со буква или бројна ознака по генеричкото име, на пример, Squatina sp. dev/files/iucn-glossary-ofdefinitions en.pdf 


\begin{tabular}{|c|c|c|c|}
\hline $\begin{array}{l}\text { Заинтереси- } \\
\text { рани страни }\end{array}$ & $\begin{array}{l}\text { Заинтересираните страни се лица или групи коишто } \\
\text { се директно или индиректно засегнати од проектот, } \\
\text { како и оние кои можеби имаат интерес за проектот } \\
\text { и/ или способност да влијаат врз неговиот резултат, } \\
\text { позитивно или негативно. Заинтересираните страни } \\
\text { може да вклучат локално засегнати заедници или } \\
\text { поединци и нивните формални и неформални } \\
\text { претставници, национални или локални власти, } \\
\text { политичари, верски лидери, грагански организации } \\
\text { и групи со посебен интерес, академска заедница } \\
\text { или други дејности. Варира „уделот“ на секој од овие } \\
\text { различни поединци или групи во проектот или } \\
\text { инвестицијата. }\end{array}$ & MФK (IFC) & $\begin{array}{l}\frac{\text { https://www.ifc.org/wps/wcm/ }}{\text { connect/938f1a0048855805b }} \\
\text { eacfe6a6515bb18//FC } \\
\text { StakeholderEngagement. } \\
\text { pdf?MOD=AJPERES }\end{array}$ \\
\hline $\begin{array}{l}\text { Вклучување } \\
\text { на заинтере- } \\
\text { сираните } \\
\text { страни }\end{array}$ & $\begin{array}{l}\text { Вклучување на заинтересираните страни е } \\
\text { генерички термин што опфаќа опсег на активности и } \\
\text { интеракции во текот на циклусот на проектот. }\end{array}$ & MФK (IFC) & $\begin{array}{l}\frac{\text { https://www.ifc.org/wps/wcm/ }}{\text { connect/938f1a0048855805b }} \\
\text { eacfe6a6515bb18//FC } \\
\text { StakeholderEngagement. } \\
\text { pdf?MOD=AJPERES }\end{array}$ \\
\hline Стратегија & $\begin{array}{l}\text { Стратегијата е долгорочен план со утврден опсег } \\
\text { со којшто се утврдуваат: мерливите цели; клучните } \\
\text { чинители и целните групи заради постигнување на } \\
\text { резултатите во согласност со истакнатата визија. }\end{array}$ & $\begin{array}{l}\text { Поимник од пакетот } \\
\text { алатки за КБР }\end{array}$ & $\begin{array}{l}\frac{\text { https://www.cbd.int/cepa/ }}{\text { toolkit/2008/doc/CBD-Toolkit- }} \\
\text { Glossaries.pdf }\end{array}$ \\
\hline $\begin{array}{l}\text { Услуги за } \\
\text { поддршка }\end{array}$ & $\begin{array}{l}\text { Екосистемски услуги што се потребни за } \\
\text { производство на сите други екосистемски услуги. } \\
\text { Некои примери вклучуваат производство на биомаса, } \\
\text { производство на атмосферски кислород, формирање } \\
\text { и задржување на почва, циклус на хранливи материи, } \\
\text { кружење на водата и обезбедување на живеалишта. }\end{array}$ & MEA & $\begin{array}{l}\frac{\text { https://www. }}{\text { millenniumassessment.org/ }} \\
\underline{\text { documents/document.776. }} \\
\underline{\text { aspx.pdf }}\end{array}$ \\
\hline Одржливост & $\begin{array}{l}\text { Се однесува на соодветен пристап, користење } \\
\text { и управување со природните ресурси, за да се } \\
\text { осигури дека мажите и жените од сегашните и } \\
\text { идните генерации можат да ги исполнуваат своите } \\
\text { основни потреби на непречена основа. Модел на } \\
\text { однесување со којшто се гарантира за секоја идна } \\
\text { генерација, можност за уживање, најмалку на истото } \\
\text { ниво на благосостојба во која уживала претходната } \\
\text { генерација. Акцентот се става врз меѓугенерациската } \\
\text { еднаквост на развојот. }\end{array}$ & Поимник на IUCN & $\begin{array}{l}\frac{\text { https://www.iucn.org/sites/ }}{\text { dev/files/iucn-glossary-of- }} \\
\text { definitions en.pdf }\end{array}$ \\
\hline Одржливо & $\begin{array}{l}\text { Во врска со дизајнирање форми на економска } \\
\text { активност и култура кои не водат кон деградација на } \\
\text { животната средина, а особено со избегнување на } \\
\text { долгорочното исцрпување на природните ресурси. }\end{array}$ & $\begin{array}{l}\text { Поимник на IUCN } \\
\text { за правото на } \\
\text { животната средина }\end{array}$ & $\begin{array}{l}\frac{\text { https://www.iucn.org/ }}{\text { theme/environmental-law/ }} \\
\text { our-work/water/water-law- } \\
\text { and-governance-support- } \\
\text { platform/learning-resources/ } \\
\text { glossary\#PStext }\end{array}$ \\
\hline $\begin{array}{l}\text { Одржливо } \\
\text { управување }\end{array}$ & $\begin{array}{l}\text { Управување преку кое постојниот потенцијал на } \\
\text { ресурсите се користи на најдобар можен начин и со } \\
\text { кое не се намалува достапноста на ресурсите. }\end{array}$ & Поимник на IUCN & $\begin{array}{l}\text { https://www.iucn.org/sites/ } \\
\text { dev/files/iucn-glossary-of- } \\
\text { definitions en.pdf }\end{array}$ \\
\hline $\begin{array}{l}\text { Одржливо } \\
\text { користење }\end{array}$ & $\begin{array}{l}\text { Употреба на компонентите од биолошката } \\
\text { разновидност на начин и по стапка со која не } \\
\text { се предизвикува долгорочно намалување на } \\
\text { биолошката разновидност, при што се одржува } \\
\text { потенцијалот за исполнување на потребите и } \\
\text { аспирациите на постојните и идните генерации. }\end{array}$ & Поимник на IUCN & $\begin{array}{l}\frac{\text { https://www.iucn.org/sites/ }}{\text { dev/files/iucn-glossary-of- }} \\
\underline{\text { definitions en.pdf }}\end{array}$ \\
\hline Синергии & $\begin{array}{l}\text { Резултат од заеднички активности што го } \\
\text { надминуваат збирот на поединечни активности и } \\
\text { напорите ги прават поефективни и поефикасни. }\end{array}$ & $\begin{array}{l}\text { Поимник на УНЕП } \\
\text { на термини за } \\
\text { преговарачи на } \\
\text { мултилатерални } \\
\text { договори за } \\
\text { животна средина } \\
\text { (2007) }\end{array}$ & $\begin{array}{l}\text { http://wedocs.unep.org/ } \\
\text { handle/20.500.11822/7569 }\end{array}$ \\
\hline
\end{tabular}


Постапка за

екосистемски

Теорија на промена

Сеопфатен опис и приказ на начинот и причините за очекувањето на посакуваната промена во определен контекст. постапки: Приказ

на влијанија и

пазарни алатки

приспособено од

Центар за теорија

на промена 2016 https://ic.fsc.org/file-

download.ecosystem-services procedure.a-7433.pdf dev/files/iucn-glossary-ofdefinitions en.pdf

\section{Компромисни решенија}

Избор што вклучува загуба на еден квалитет или услуга (на екосистем) за сметка на добивање друг квалитет или услуга. Голем број одлуки што влијаат врз екосистемите вклучуваат компромисни решенија, понекогаш главно и долгорочно.
Поимник на IUCN

Традиционалното еколошко знаење (TEK) се вербално меѓугенерациски пренесени знаења, практики и убедувања (Berkes, 2008), со што се опфаќа силна културна еколошка меморија и чувствителност на промена и што зависи од опстанокот на живите култури во нивните домодорни места. Традиционалното еколошко знаење (TEK) е комплементарно на западната наука и управување со ресурси во заштитените подрачіа, особено во оваа ера на брзи промени во животната средина. Ова е потврдено од еколозите на Еколошкото друштво на Америка (ЕСА) во журналот Граници во екологијата: „Просторно изричитото

Традиционално знаење локално знаење е особено важно за идентификација на праговите или критичните точки... домородните народи имаат интимно знаење за просторните и временските варијабилности како забележливи показатели кои, кога ќе се комбинираат со научното разбирање... може да се употребат за развој на веродостојни описи на референтните услови за оценка (на животната средина)..." (Herrick et al., 2010). Традиционалните културни практики, во својот поголем дел, беа еколошки одржливи. Паркови Канада и Советот на канадските паркови (2008) ги препознаваат долготрајните, тестираните, еколошки соодветните практики како еколошки вредности коишто треба да се обноват или да се одржат.

Еколошка обнова за заштитени подрачја https://portals.iucn.org/ library/sites/library/files/ documents/PAG-018.pdf

\begin{tabular}{|c|c|c|c|}
\hline $\begin{array}{l}\text { Традицио- } \\
\text { нална } \\
\text { употреба }\end{array}$ & $\begin{array}{l}\text { Искористување на природните ресурси од страна } \\
\text { на домородни корисници или недомородни жители } \\
\text { со употреба на традиционални методи. Локалната } \\
\text { употреба се однесува на искористување од страна на } \\
\text { локалните жители. }\end{array}$ & $\begin{array}{l}\text { Милениумски } \\
\text { екосистемски услуги } \\
\text { - МЕА }\end{array}$ & $\begin{array}{l}\frac{\text { https://www. }}{\text { millenniumassessment.org/ }} \\
\text { documents/document.776. } \\
\text { aspx.pdf }\end{array}$ \\
\hline $\begin{array}{l}\text { Транспарен- } \\
\text { тност }\end{array}$ & $\begin{array}{l}\text { Транспарентноста се однесува на средина во } \\
\text { која целите на политиката, нејзината правна, } \\
\text { институционална и економска рамка, политичките } \\
\text { одлуки и нивното образложение, податоците } \\
\text { и информациите поврзани со монетарните и } \\
\text { финансиските политики и условите за отчетност на } \\
\text { агенциите се обезбедуваат за јавноста на сеопфатен, } \\
\text { пристапен и навремен начин. }\end{array}$ & ОЕЦД & $\frac{\text { https://stats.oecd.org/ }}{\text { glossary/detail.asp?ID=4474 }}$ \\
\hline Несигурност & $\begin{array}{l}\text { Изразување степен до којшто идниот услов (на } \\
\text { екосистем) е непознат. Несигурноста може да } \\
\text { е резултат од недостиг од информации или од } \\
\text { несогласување за тоа што е познато или што може } \\
\text { да се знае. Може да има голем број видови извори, } \\
\text { од грешки кои може да се квантифицираат во однос } \\
\text { на податоците за нејасно дефинирана терминологија } \\
\text { или несигурни проекции на човековото однесување. } \\
\text { Следствено, несигурноста може да биде претставена } \\
\text { со квантитативни мерки (на пример, опсег на } \\
\text { вредности што се пресметуваат со различни } \\
\text { модели) или со квалитативни изјави (на пример, } \\
\text { разгледување одлука на тим експерти). }\end{array}$ & $\begin{array}{l}\text { Милениумски } \\
\text { екосистемски услуги } \\
\text { - МЕА }\end{array}$ & $\begin{array}{l}\frac{\text { https://www. }}{\text { millenniumassessment.org/ }} \\
\text { documents/document.300. } \\
\text { aspx.pdf }\end{array}$ \\
\hline
\end{tabular}


Терминот „унапредување/зголемување на вредноста" денес се користи на различни начини. Во некои дискусии широко се однесува на „да се направи повеќе“, како на пример во „подобрување на третманот на ХИВ/СИДА". ExpandNet го дефинира овој термин поконкретно како: намерни напори за зголемување на влијанието од успешно тестираните иновации во здравството за да се обезбедат придобивки за повеќе луѓе и за да се промовира развој на програми и политики врз долготрајна основа. "Иновации" се однесува на компоненти за услуги, други практики или производи што се нови или се перципираат како нови. Иновациите обично

Унапредување (зголемување на вредност) се состојат од „пакет интервенции", вклучувајќи ја не само новата технологија, клиничката практика, образовната компонента или иницијативата на заедницата, туку и раководните процеси потребни за успешно спроведување. Со „успешно тестирано“ се истакнува дека интервенциите што се прошируваат треба да бидат поддржани од локално создадени докази за ефективност на програмата и изводливост, коишто се добиени преку пилот, демонстративни или експериментални проекти или преку првично воведување во ограничен број локални места. Со „намерни напори“, унапредувањето се одбележува како насочуван процес, во контраст со спонтаната дифузија на иновации. Со „развој на програми и политики врз долготрајна основа" се истакнува значењето на институционалното градење на капацитет и одржливоста. http://www.who.int/ immunization/hpv/deliver/ nine steps for developing a scalingup strategy who 2010. pdf

„Капацитет на населението да го заштити одржливиот пристап до соодветни количества прифатлив квалитет на вода за одржливо живеење, човекова благосостојба и социоекономски развој, со Достапност на цел осигурување заштита од загадување на водата и вода катастрофи поврзани со водата и заради зачувување на екосистемите во клима на мир и политичка

UN Water (Програма за вода на $\mathrm{OH}$ стабилност" Ова е дефиницијата што ја предлага Програмата за вода на ОН за да служи како појдовна точка за дијалог во системот на ОН. htto://www.unwater org/ publications/water-securityinfographic/
Област на земја која обезбедува вода за река и која минува низ пределот во притоките и каналите на главната река. Се нарекува и зафат, одводен слив или речен слив.
Поимник на IUCN

https://www.iucn.org/sites/ dev/files/iucn-glossary-ofdefinitions en.pdf 


\section{Користена литература}

CBD (Convention on Biological Diversity) (2004). The Ecosystem Approach (CBD Guidelines). Montreal: Secretariat of the Convention on Biological Diversity. 50 pp.

Cohen-Shacham, E., Walters, G., Janzen, C. and Maginnis, S. (2016). Nature-Based Solutions to Address Societal Challenges. Gland, Switzerland: International Union for Conservation of Nature. 10.2305/IUCN.CH.2016.13.en

Cohen-Shacham, E., Andrade, A., Dalton, J., Dudley, N., Jones, M., Kumar, C., Maginnis, S., Maynard, S., Nelson, C., Renaud, F., Welling, R. and Walters, G. (2019). Core principles for successfully implementing and upscaling Nature-based Solutions. Environmental Science and Policy 98: 20-29. https://doi.org/10.1016/j. envsci.2019.04.014

de Coninck, H., Revi, A., Babiker, M., Bertoldi, P., Buckeridge, M., Cartwright, A., Dong, W., Ford, J., Fuss, S., Hourcade, J.-C., Ley, D., Mechler, R., Newman, P., Revokatova, A., Schultz, S., Steg, L. and Sugiyama, T. (2018). Strengthening and Implementing the Global Response. In: Global Warming of $1.5^{\circ} \mathrm{C}$. An IPCC Special Report on the impacts of global warming of $1.5^{\circ} \mathrm{C}$ above preindustrial levels and related global greenhouse gas emission pathways, in the context of strengthening the global response to the threat of climate change, sustainable development, and efforts to eradicate poverty. IPCC. https://www. ipcc.ch/report/sr15/chapter-4-strengtheningand-implementing-the-global-response/
Holling, C.S (1973). Resilience and stability of ecological systems. Annual Review of Ecology and Systematics 4: 1-23. https://doi. org/10.1146/annurev.es.04.110173.000245

Holling, C.S. (ed.) (1978). Adaptive Environmental Assessment and Management. London: John Wiley and Sons. 377 pp.

Holling, C.S. (1986). The resilience of terrestrial ecosystems: local surprise and global change. In: W.C. Clark and R.E. Munn (eds.), Sustainable Development of the Biosphere, (Chap. 10: 292317). Cambridge, U.K.: Cambridge University Press.

IPBES (Intergovernmental Science-Policy Platform on Biodiversity and Ecosystem Services) (2019a). Global assessment report on biodiversity and ecosystem services of the Intergovernmental Science- Policy Platform on Biodiversity and Ecosystem Services. E.S. Brondizio, J. Settele, S. Díaz and H.T. Ngo (eds.). Bonn, Germany: IPBES Secretariat. https://ipbes.net/global-assessment

IPBES (Intergovernmental Science- Policy Platform on Biodiversity and Ecosystem Services) (2019b). Summary for policymakers of the global assessment report on biodiversity and ecosystem services of the Intergovernmental Science-Policy Platform on Biodiversity and Ecosystem Services. S. Díaz, J. Settele, E.S. Brondízio, H.T. Ngo, M. Guèze, J. Agard, A. Arneth, P. Balvanera, K.A. Brauman, S.H.M. Butchart, K.M.A. Chan, L.A. Garibaldi, K. Ichii, J. Liu, S.M. Subramanian, G.F. Midgley, P. Miloslavich, Z. Molnár, D. Obura, A. Pfaff, S. Polasky, A. Purvis, J. Razzaque, B. Reyers, 
R. Roy Chowdhury, Y.J. Shin, I.J. VisserenHamakers, K.J. Willis and C.N. Zayas (eds.). Bonn, Germany: IPBES Secretariat. 56 pp. https://ipbes.net/news/global-assessmentsummary-policymakers-final-version-nowavailable

IPCC (Intergovernmental Panel on Climate Change) (2018). Global Warming of $1.5^{\circ} \mathrm{C}$. An IPCC Special Report on the impacts of global warming of $1.5^{\circ} \mathrm{C}$ above pre-industrial levels and related global greenhouse gas emission pathways, in the context of strengthening the global response to the threat of climate change, sustainable development, and efforts to eradicate poverty. IPCC. https://www.ipcc.ch/sr15/

IPCC (Intergovernmental Panel on Climate Change) (2019). IPCC Special Report on Climate Change, Desertification, Land Degradation, Sustainable Land Management, Food Security, and Greenhouse Gas Fluxes in Terrestrial Ecosystems. Summary for Policymakers. IPCC. https://www.ipcc.ch/srccl/

IUCN (International Union for Conservation of Nature) (2016). Resolution 69 on Defining Nature-based Solutions (WCC-2016-Res-069). IUCN Resolutions, Recommendations and Other Decisions 6-10 September 2016. World Conservation Congress Honolulu, Hawai'i, USA. https://portals.iucn.org/library/sites/ library/files/resrecfiles/WCC_2016_RES_069_ EN.pdf

OECD (Organisation for Economic Co-operation and Development) (2020). http://www.oecd. org/dac/financing-sustainable-development/ blendedfinance-principles/ accessed: 11 May 2020 .

PWC and WWF (World Wide Fund for Nature) (2020). Nature is too big to fail - Biodiversity: the next frontier in financial risk management.
Switzerland: PwC and WWF. http://www.pwc. ch/wwf-report

Rockström, J., Steffen, W., Noone, K. et al. (2009). A safe operating space for humanity. Nature 461: 472-475. https://doi. org/10.1038/461472a

Rogers, K.H., Luton, R., Biggs, H., Biggs, R., Blignaut, S., Choles, C.G., Palmer, A.G. and Tangwe, P. (2013). Fostering complexity thinking in action research for change in social-ecological systems. Ecology and Society 18(2): 31, 10.5751/ES-05330-180231

Sharp, R., Tallis, H.T., Ricketts, T., Guerry, A.D., Wood, S.A., Chaplin-Kramer, R., Nelson, E., Ennaanay, D., Wolny, S., Olwero, N., Vigerstol, K., Pennington, D., Mendoza, G., Aukema, J., Foster, J., Forrest, J., Cameron, D., Arkema, K., Lonsdorf, E., Kennedy, C., Verutes, G., Kim, C.K., Guannel, G., Papenfus, M., Toft, J., Marsik, M., Bernhardt, J., Griffin, R., Glowinski, K., Chaumont, N., Perelman, A., Lacayo, M. Mandle, L., Hamel, P., Vogl, A.L., Rogers, L., Bierbower, W., Denu, D. and Douglass, J. (2020). InVEST User Guide. The Natural Capital Project, Stanford University, University of Minnesota, The Nature Conservancy, and World Wildlife Fund.

Smith, R.D. and Maltby, E. (2003). Using the Ecosystem Approach to implement the Convention on Biological Diversity: Key issues and Case Studies. Gland, Switzerland and Cambridge, UK: IUCN. https://doi.org/10.2305/ IUCN.CH.2003.CEM.2.en

Steffen, W., Richardson, K., Rockstrom, J., Cornell, S.E., Fetzer, I., Bennett, E.M., Biggs, R., Carpenter, S.R., de Vries, W. and de Wit, C.A. (2015). Planetary boundaries: guiding human development on a changing planet. Science. https://doi.org/10.1126/science.1259855 
Waltner-Toews, D. and Kay, J. (2005). The evolution of an ecosystem approach: the diamond schematic and an adaptive methodology for ecosystem sustainability and health. Ecology and Society 10(1): 38. https:// doi.org/10.5751/ES-01214-100138 



\section{IUCN}

МЕЃУНАРОДНА УНИЈА ЗА ЗАШТИТА НА ПРИРОДАТА

СЕДИШТЕ

ул. Моверни 28

1196 Глан, Швајцарија

Tel +41 229990000

Fax +41 229990002

NbSStandard@iucn.org

www.iucn.org 